\title{
FEDERAL COMMON LAW IN AN AGE OF TREATIES
}

\author{
Michael P. Van Alstine†
}

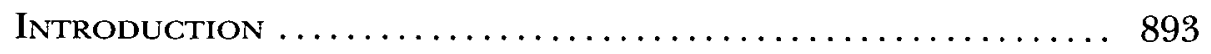

I. The Force and Significance of the Modern Treaty Power................................ 900

A. Constitutional Background and Text: The Role of Treaties as Directly Applicable Federal Law ........ 900

1. Federal Power, Foreign Affairs, and Treaties........ 900

2. Treaties and the Self-Execution Doctrine............ 904

B. Responding to the Revisionist Challenge to SelfExecution .............................. 907

1. The Challenge and the Historical Debate .......... 907

2. Confirmation Through Action: The Post-Ratification Conduct of the Political Branches on Self-Execution . 910

3. Confirmation Through Jurisprudence: Supreme Court Precedent and Self-Execution ................ 913

C. The Pervasive Role of Treaties in Our Modern Legal Landscape......................... 917

1. Self-Executing Treaties: Attributes and Functions..... 917

2. The Broad Substantive Influence of Self-Executing Treaties .............................. 921

I1. The Constitutional Limits on Federal Judicial

LAWMAKInG . . . . . . . . . . . . . . . . . . . . . . . 927

A. Boundaries of Federal Common Law ........... 927

B. Jurisprudence Concerning Permitted Federal Common Law ......................... 931

1. Delegated Lawmaking.................. 931

2. The "Enclaves" of Federal Common Law .......... 937

C. Federal Common Law and the Preemption

Doctrine................................... 941

$\dagger$ Professor of Law, University of Maryland School of Law; J.D., 1986, The George Washington University; M. Jur. Comp., 1992, University of Bonn, Germany; Dr. Jur., 1994, University of Bonn, Germany. I presented an earlier version of this article at a scholarship conference on international law in domestic courts held at the Fordham University Law School, and I thank the participants for their numerous and insightful comments. Special thanks go to Martin Flaherty, Curtis Bradley, and David Sloss. I also thank Nicholas Reuhs and Shannon Chilcoate for their excellent research assistance. I am also indebted to Graeme Dinwoodie, Mark Movsesian, David Sloss, Carlos Vázquez, and Greg Young for constructive comments on earlier drafts. 
III. Treaty Power, Judicial Power, and Delegated

Federal Court LaWmaking. . . . . . . . . . . . . . . . . . . . . 944

A. The Relationship of the Treaty Power to the Judicial

Power ................................... 944

1. The Judicial Power and the Treaty Power .......... 944

2. The Constitutional Nature of Treaties ........... 948

3. The Judicial Power and the Executive Power......... 951

B. The Constitutionality of an Express Delegation of

Lawmaking Powers Through Treaties ........... 954

1. Background...................... 954

2. Vertical Allocations of Power: Express Treaty

Delegation and Federalism................ 956

3. Horizontal Allocations of Power: Express Treaty

Delegation and the Separation of Powers Doctrine ... . 961

a. Potential Conflicts with Congress's Legislative

Power ................................. 961

b. The Non-Delegation Doctrine............ 963

C. Conclusion: Express Delegation and Federal Court

Lawmaking Under Treaties . ............. 966

IV. Presumptive Federal Law in an Age of Treaties ..... 967

A. Present State of Confusion ............... 967

B. Treaties and a Presumption of Federal Law ........ 971

1. Dismantling the Presumption Against Preemption .... 971

2. Treaties and Interstitial Judicial Lawmaking ....... 978

a. The Uniquely Federal Interest in Contractual Obligations of Treaties ................ 978

b. Differentiating Gaps Intra Legem from Gaps Praeter Legem...................... 983

c. Interstitial Lawmaking and Error Costs........ 984

C. Treaties and Separation of Powers Concerns

Regarding Federal Court Lawmaking ............ 986

Conclusion $\ldots \ldots \ldots \ldots \ldots \ldots \ldots \ldots \ldots \ldots \ldots \ldots \ldots \ldots \ldots \ldots . \ldots \ldots$

Except in matters governed by the Federal Constitution or by Acts of Congress, the law to be applied in any case is the law of the State. ${ }^{1}$

\section{INTRODUCTION}

This declaration in Erie Railroad Co. $v$. Tompkins established one of the most profound and enduring principles of the U.S. constitutional system. Instituting "something of a constitutional revolution,"2 the Supreme Court in Erie reasoned that courts of the United States must

1 Erie R.R. Co. v. Tompkins, 304 U.S. 64, 78 (1938).

2 Bradford R. Clark, Federal Common Law: A Structural Reinterpretation, 144 U. PA. L. REV. 1245, 1256 (1996). 
apply state substantive law, unless such law is displaced by the Constitution or Congress acting pursuant to specific, enumerated lawmaking authority. ${ }^{3}$ What is striking about this declaration, however, is that it is, and was even at the time, patently incomplete.

Missing from the core holding in Erie-indeed from the entire opinion-is any mention of treaties as a valid source of federal law. Article VI of the Constitution expressly includes treaties as the "supreme Law of the Land." 4 Relying on this provision, the Supreme Court established well over a century before Erie that, in addition to the "Constitution or . . . Acts of Congress," States also may operate as directly applicable federal law. ${ }^{6}$ Indeed, these "self-executing" treaties represent a particularly powerful vehicle for legal change. The combined effect of the Supremacy Clause ${ }^{7}$ and the constitutional treaty power ${ }^{8}$ is that the President and the Senate may create federal law without the involvement of the House of Representatives, even though Article I states that "[a]ll legislative Powers herein granted" are vested in Congress as a whole. ${ }^{9}$

For most of this country's legal history, treaties triggered only episodic controversies over parochial concerns. ${ }^{10}$ But just as the nation's

3 See Erie, 304 U.S. at 78 (

Congress has no power to declare substantive rules of common law applicable in a State whether they be local in their nature or "general," be they commercial law or a part of the law of torts. And no clause in the Constitution purports to confer such a power upon the federal courts.

) .

4 U.S. Const. art. VI, cl. 2 (providing that "all Treaties made, or which shall be made, under the Authority of the United States, shall be the supreme Law of the Land").

5 Erie, 304 U.S. at 78; see Reid v. Covert, 354 U.S. 1, 18 (1957) (noting the distinction between a treaty and an "Act of Congress"). The Rules of Decision Act, the core statute regarding the law that federal courts must apply, draws the same distinction. See 28 U.S.C. $\$ 1652$ (2000) (providing that federal courts must apply state law "except where the Constitution or treaties of the United States or Acts of Congress otherwise require or provide"). Because of its obvious importance for the powers of federal courts, 1 analyze this important legislation in significant detail below. See infra notes $214-16,394-96$, and $429-30$ and accompanying text.

6 See Foster v. Neilson, 27 U.S. (2 Pet.) 253, 314 (1829) (holding that a treaty is "to be regarded in courts of justice as equivalent to an act of the legislature, whenever it operates of itself without the aid of any legislative provision"), overruled on other grounds by United States v. Percheman, 32 U.S. (Pet.) 51, 52 (1833); see also discussion infra Part I.A.2 (analyzing the "self-execution" doctrine in greater detail).

7 U.S. Const. art. VI, cl. 2 (stating that the "Constitution, and the Laws of the United States . . and all Treaties made, or which shall be made, under the Authority of the United States, shall be the supreme Law of the Land").

8 Id. art. II, $\S 2$, cl. 2 (providing that the President shall have the power to make treaties "by and with the Advice and Consent of the Senate..., provided two thirds of the Senators present concur").

9 Id. art. I, \$ 1.

10 There are several prominent examples of these episodic controversies. See Curtis A. Bradley \& Jack L. Goldsmith, Treaties, Human Rights, and Conditional Consent, 149 U. PA. L. REv. 399, 410-16 (2000) (discussing how human rights treaties provoked the proposed "Bricker Amendment"); David M. Golove, Treaty-Making and the Nation: The Historical Foun- 
maturing legal culture and economy led to broader exercises of federal statutory power in the twentieth century, so too in recent years the expansion of cross-border legal interaction has spawned a greater need for broad international solutions. The result is that treaties now cover a broad and growing field of substantive law in the modern legal landscape. ${ }^{11}$

The expanding influence of treaty law in recent years has triggered substantial scholarly debate. ${ }^{12}$ For instance, one prominent line of attack argues that the constitutional premise of federalism places significant substantive limits on the operation of treaties as domestic law. ${ }^{13}$ A leading scholar has even mounted an aggressive challenge to the very constitutionality of self-executing treaties. ${ }^{14}$ This attack has provoked an equally forceful response by other scholars, ${ }^{15}$ with some arguing that the Constitution requires judicial enforcement of all rati-

dations of the Nationalist Conception of the Treaty Power, 98 MicH. L. Rev. 1075 (2000) (discussing the treaty protections of British creditors and land owners after the Revolutionary War, including the 1782 Treaty of Peace, which resuscitated some of the debt that states had discharged, and the Jay Treaty, which protected British owners of land in the United States); id. at 1246-54, 1273-78 (analyzing post-Civil War states' rights arguments seeking to discriminate against Chinese and Japanese immigrants notwithstanding protected treaty rights).

11 See infra Part I.C.2 (analyzing the modern influence of self-executing treaties).

12 For example, the creation of the World Trade Organization (WTO) and the North American Free Trade Agreement (NAFTA) via standard Article I legislation led to a heated debate among this country's leading constitutional law scholars over the propriety of this alternative to the Article II treaty process. Compare Bruce Ackerman \& David Golove, Is NAFTA Constitutional?, 108 HARv. L. Rev. 799, 907-25 (1995) (arguing that congressionalexecutive agreements, which led to the approval of the WTO agreements and NAFTA, are constitutional), with Laurence H. Tribe, Taking Text and Structure Seriously: Reflections on FreeForm Method in Constitutional Interpretation, 108 HARv. L. Rev. 1221, 1249-1301 (1995) (suggesting that these alternative means of consent to treaties are unconstitutional).

13 See Curtis A. Bradley, The Treaty Power and American Federalism, 97 MicH. L. Rev. 390, 450-61 (1998) [hereinafter Bradley, Treaty Power] (arguing that the federalism limitations of the enumerated powers doctrine justify placing substantive limits on the scope of the treaty power). But see Golove, supra note 10, at 1278-1313 (challenging Professor Bradley's arguments based on historical, structural, and textual analyses of the treaty power). Professor Bradley asserts, however, that recent Supreme Court federalism decisions are contrary to Professor Golove's criticisms. See Curtis A. Bradley, The Treaty Power and American Federalism, Part II, 99 Mich. L. REv. 98, 111-18 (2000) [hereinafter Bradley, Treaty Power II]. For a detailed examination of these competing claims, see Edward T. Swaine, Does Federalism Constrain the Treaty Power?, 103 Colum. L. Rev. 403, 413-93 (2003).

14 See John C. Yoo, Globalism and the Constitution: Treaties, Non-Self-Execution, and the Original Understanding, 99 Colum. L. REv. 1955, 1982-2094 (1999) [hereinafter Yoo, NonSelf-Execution]; John C. Yoo, Treaties and Public Lawomaking: A Textual and Structural Defense of Non-Self-Execution, 99 Colum. L. Rev. 2218, 2221-57 (1999) [hereinafter Yoo, Treaties and Public Lawmaking].

15 See generally Martin S. Flaherty, History Right?: Historical Scholarship, Original Understanding, and Treaties as "Supreme Law of the Land,"99 Colum. L. Rev. 2095 (1999) (defending the constitutionality of self-executing treaties against Yoo's attack); Carlos Manuel Vázquez, Laughing at Treaties, 99 Colum. L. Rev. 2154 (1999) (same); see also discussion infra Part I.B (examining the debate over the constitutionality of self-executing treaties). 
fied treaties as federal law. ${ }^{16}$ Recent exchanges ${ }^{17}$ also have reinvigorated the dormant controversy over the President's power to reinterpret treaties without involving the Senate ${ }^{18}$ or, indeed, even the Supreme Court. ${ }^{19}$

These heated disputes over the domestic force of treaty law have proceeded in seeming parallel to a separate, yet equally contentious, debate over the role of federal courts in our modern regulatory state. On the international plane, revisionist scholars have criticized the accepted view that international law may operate directly as federal common law. ${ }^{20}$ Likewise, profound conservative distrust of the discretionary powers of federal courts has spawned "new textualist" approaches to statutory interpretation. ${ }^{21}$ In addition, this distrust fa-

16 See Jordan J. Paust, Self-Executing Treaties, 82 AM. J. INT'L L. 760, 760 (1988) (arguing that " $[\mathrm{t}]$ he distinction found in certain cases between 'self-executing' and 'non-self-executing' treaties is a judicially invented notion that is patently inconsistent with express language in the Constitution affirming that "all Treaties ... shall be the supreme Law of the Land' "); cf. David Sloss, Non-Self-Executing Treaties: Exposing a Constitutional Fallacy, 36 U.C. Davis L. REv. 1, 6 (2002) (arguing in favor of a strong presumption of self-execution as a matter of domestic constitutional law, and noting that an unlimited notion of non-selfexecution "is at odds with fundamental precepts concerning the role of an independent judiciary in preserving the rule of law").

17 For example, the Reagan administration contended that it had the right to reinterpret the Anti-Ballistic Missile Treaty with the Soviet Union, which provoked a heated debate in both political circles and legal scholarship. See, e.g., Lawrence J. Block et al., The Senate's Pie-in-the-Sky Treaty Interpretation: Power and the Quest for Legislative Supremacy, $137 \mathrm{U}$. PA. L. Rev. 1481, 1493-1509 (1989) (contending that Professor Kaplow and others' interpretations result in a great deal of constitutional uncertainty); David A. Kaplow, Constitutional Bait and Switch: Executive Reinterpretation of Arms Control Treaties, 137 U. PA. L. Rev. $1353,1389-1412$ (1989) (discussing the constitutional role of the executive in treaty interpretation); Eugene V. Rostow, The Reinterpretation Debate and Constitutional Law, 137 U. PA. L. REv. 1451, 1453-60 (1989) (criticizing Professor Kaplow's substantive analysis as "ha[ving] a number of revealing errors").

18 See John Yoo, Politics as Law?: The Anti-Ballistic Missile Treaty, the Separation of Powers, and Treaty Interpretation, 89 CAL. L. REv. 851, 867-82 (2001) (book review).

19 See John C. Yoo, Treaty Interpretation and the False Sirens of Delegation, 90 CAL. L. REv. $1305,1314-28$ (2002) (disagreeing with the proposition that final interpretive authority over treaties is vested in the Supreme Court). But see Michael P. Van Alstine, The Judicial Power and Treaty Delegation, 90 CAL. L. REv. 1263, 1275-80 (2002) (rejecting the contention that the President has "unilateral authority" to reinterpret treaties).

20 See Curtis A. Bradley \& Jack L. Goldsmith, Customary Intermational Law as Federal Common Law: A Critique of the Modern Position, 110 HARv. L. REv. 815, 849-70 (1997) (criticizing the "nationalist" view that federal courts have the power to apply norms of customary international law as an element of federal common law); see also Jack L. Goldsmith, Federal Courts, Foreign Affairs, and Federalism, 83 VA. L. Rev. 1617, 1664-98 (1997) (challenging the view that federal courts may apply international law as an element of the foreign affairs category of federal common law). But see Harold Hongju Koh, Is International Law Really State Law?, 111 HaRv. L. Rev. 1824, 1830-60 (1998) (disagreeing with Bradley \& Goldsmith's critique).

21 See William N. Eskridge, Jr., The New Textualism, 37 UCLA L. Rev. 621, 640-66 (1990) (reviewing tbe emergence of textualist approaches to statutory interpretation); see also Antonin Scalia, A MATTER OF INTERPRETATION 29-37 (1997) (supporting an interpretive approach that adheres closely to statutory text and criticizing the use of legislative 
cilitated the advent of the "Chevron Doctrine" to limit federal court review of executive branch interpretations of statutes, ${ }^{22}$ and aggressive policing of the "presumption against preemption" to protect against overly liberal judicial displacements of state law with federal statutes. ${ }^{23}$

With the progressive growth of treaties as judicially enforceable federal law, these two major strains of modern scholarly debate converge. Unfortunately, little is known about the proper role of federal courts in the interpretation and application of treaty law. Indeed, even though there are many self-executing treaties, there is a dearth of reliable, comprehensive studies on the subject. ${ }^{24}$ For its part, Supreme Court precedent on the interpretation of treaties, though often consistent in rhetoric, has failed to provide a coherent approach to accommodate the substantive diversity of modern treaties. ${ }^{25}$

Substantial uncertainty also reigns in the Court over the preemptive force of treaties. ${ }^{26}$ This subject recently provoked a spirited exchange between the otherwise philosophically-aligned Justices Ginsburg and Stevens. ${ }^{27}$ Existing guidance from the Court on federal

history by federal courts on this score); Frank H. Easterbrook, Text, History, and Structure in Statutory Interpretation, 17 HARv. J.L. \& PUB. PoL'y 61, 62-67 (1994) (same).

22 See Chevron U.S.A., Inc. v. Natural Res. Def. Council, 467 U.S. 837, 842-44 (1984) (holding that federal courts must defer to an agency's interpretation of a statute if it is either not contrary to the unambiguously expressed intent of Congress or, where Congress is silent, the interpretation is reasonable); see also FDA v. Brown \& Williamson Tobacco Corp., 529 U.S. 120, 159 (2000) ("Deference under Cheoron to an agency's construction of a statute that it administers is premised on the theory that a statute's ambiguity constitutes an implicit delegation from Congress to the agency to fill in the statutory gaps.").

23 See, e.g., Pharm. Research \& Mfrs. of Am. v. Walsh, 123 S. Ct. 1855, 1867 (2003) (citing initial presumption of state statute's validity in holding that federal Medicaid law does not preempt Maine's "prior authorization" requirement for drug companies that do not enter rebate agreements); Medtronic, lnc. v. Lohr, 518 U.S. 470, 494 (1996) (holding that a federal statute which allows certain products to remain on the market even without FDA approval does not preempt negligent design claims under Florida law); see also infra notes 463-67 and accompanying text (analyzing this presumption in detail).

24 The goal of Part 1.C.2 below is to address this significant gap in knowledge.

25 See David J. Bederman, Revivalist Canons and Treaty Interpretation, 41 UCL.A L. REV. 953, 975-1019 (1994) (critically reviewing the Rehnquist Court's treaty interpretation); Michael P. Van Alstine, Dynamic Treaty Interpretation, 146 U. PA. L. REv. 687, 707-09 (1998) (questioning the utility of Supreme Court precedent for many categories of modern private law treaty interpretation).

26 See infra notes 470-79 and accompanying text (analyzing the conflicting pronouncements of the Supreme Court on this score).

27 Compare El Al lsr. Airlines, Ltd. v. Tsui Yuan Tseng, 525 U.S. 155, 175 (1999) (Ginsburg, J., for the majority) ("Our home-centered preemption analysis . . should not be applied, mechanically, in construing our international obligations."), with id. at 177 (Stevens, J., dissenting) (criticizing the "novel premise that preemption analysis should be applied differently to treaties than to other kinds of federal law"). See also infra notes 477-79 and accompanying text for a more detailed analysis of this issue and the dispute between Justice Ginsburg and Justice Stevens. 
court lawmaking under treaties likewise is cryptic at best. ${ }^{28}$ Even the most thoughtful scholars of general federal common law either fail to address the subject of treaty law at all or mention it only in passing. ${ }^{29}$

The continued uncertainty over the relationship between the judicial power of federal courts and the treaty power of the President and Senate provides the foundation for this Article. The initial two Parts set, respectively, the general and specific contexts for the analysis that follows. Part I first reviews the constitutional foundation for the operation of treaties as directly applicable federal law. ${ }^{30}$ But more importantly, Part I fills the sizable gap in knowledge about the substantive influence of self-executing treaties. This Part will show that treaties currently regulate a wide range of domestic law subjects, from public to private law, commercial to criminal law, family to tax law, and even aspects of administrative law and civil procedure. ${ }^{31}$

Part II then provides the legal framework for understanding the lawmaking powers of federal courts. It first examines the premise of Erie and its progeny that the Constitution generally prohibits federal court lawmaking. As a result of this limitation, it follows that any particular rule of federal common law must stem from a specific, independent grant of authority. ${ }^{32}$ In the statutory context, the Supreme Court nonetheless has long held that federal courts may obtain lawmaking powers from an express or implied delegation by Congress. ${ }^{33}$ But Part II also explains that the Constitution itself authorizes federal common law in certain areas of "uniquely federal interest," especially

28 See, e.g., Zicherman v. Korean Air Lines Co., 516 U.S. 217, 229 (1996) (holding that the Warsaw Convention did not "empower [the Court] to develop some common-law rule," but expressing no discernible doubt about the legality of such an authorization).

29 See Martha A. Field, Sources of Law: The Scope of Federal Common Law, 99 HARv. L. Rev. 881,889 (1986) (arguing without analysis of the specific point that "the process and standards for making federal common law are the same when a treaty . . . is the source of authority"); Thomas W. Merrill, The Common Law Powers of Federal Courts, 52 U. CHI. L. REv. 1, 6, 28 (1985) (noting that federal common law includes "all federal rules of decision not mandated on the face of a federal text-that is, a federal statute or treaty or the Constitution," and remarking that the Rules of Decision Act contains a reference to "treaties," but otherwise not analyzing federal common law under treaties); Henry P. Monaghan, The Supreme Court, 1974 Term-Foreword: Constitutional Common Law, 89 Harv. L. Rev. 1, 12 (1975) (observing that federal courts "must point to some source, such as a statute, treaty, or constitutional provision, as authority for the creation of substantive federal law"); Martin H. Redish, Federal Common Law, Political Legitimacy, and the Interpretive Process: An "Institutionalist" Perspective, 83 Nw. U. L. REv. 761, 786 (1989) (mentioning the inclusion of treaties in the Rules of Decision Act only as part of a comprehensive analysis of the propriety of federal common law).

3o See discussion infra Part 1.A-B.

31 See discussion infra Part I.C.2; see also discussion infra Part I.C.1 (analyzing the attributes and functions of self-executing treaties).

32 See discussion infra Part Il.A.

33 See, e.g., Loving v. United States, 517 U.S. 748, 758 (1996) ("Congress must be permitted to delegate to others at least some authority that it could exercise itself"); see also discussion infra Part II.B.1. 
in foreign affairs and in the definition of the federal government's sovereign obligations. ${ }^{34}$

With this foundation, the remainder of the Article is devoted to an analysis of the lawmaking powers of federal courts as applied to treaties. To provide a context for this analysis, Part III first demonstrates that the judicial relationship with self-executing treaty law originates from the same source of authority as Article I legislation. ${ }^{35}$ No less than in the statutory context, therefore, a deliberate and circumscribed delegation of lawmaking powers by treaty ${ }^{36}$ does not run afoul of federalism or separation of powers limitations on federal judicial lawmaking. ${ }^{37}$ With such an express delegation of authority, in other words, interstitial lawmaking does not represent " an unconstitutional assumption of powers by [the] [C]ourts of the United States." "38

Even beyond an express authorization, much of the confusion over the powers of federal courts dissipates upon examination of the special character and function of treaties. As Part IV explains, treaties by their nature represent a formal exercise of the federal government's exclusive authority over the creation of international obligations of the United States. ${ }^{39}$ This fundamental difference with the shared legislative powers of Article I substantially undermines the traditional presumption against preemption of state law in the treaty context. Indeed, for unresolved issues regarding self-executing treaties, the more compelling arguments support a presumption in favor of federal law solutions. ${ }^{40}$

More broadly, the special constitutional nature of treaties also profoundly affects the analysis of the lawmaking powers of federal courts. As a formal expression both of national foreign policy and of U.S. international law obligations, treaty law, as Part IV finally demonstrates, operates at the intersection of the two most prominent fields of recoguized federal common law. ${ }^{41}$ This alone, to be sure, does not

34 See discussion infra Part II.B.2; see also discussion infra Part II.C (examining the interaction between federal common law and the preemption doctrine).

35 See discussion infra Part III.A.

36 One comprehensive commercial law convention exemplifies a deliberate delegation of lawmaking powers. See infra notes 405-12 and accompanying text (describing the delegation of enhanced developmentaI powers in the UN Convention on Contracts for the International Sale of Goods).

37 See discussion infra Part III.B-C.

38 Erie R.R. Co. v. Tompkins, 304 U.S. 64, 79 (1938) (quoting Black \& White Taxicab \& Transfer Co. v. Brown \& Yellow Taxicab \& Transfer Co., 276 U.S. 5I8, 533 (I928) (Holmes, J., dissenting)).

39 See infra notes 490-507 and accompanying text; see also infra Part IV.B.I (analyzing the broader relationsbip of treaty law with preexisting state law).

40 See discussion infra Part IV.B.l.

41 See discussion infra Part IV.B.2. 
sanction federal court lawmaking for all issues of treaty law, ${ }^{42}$ and separation of powers may counsel special caution by federal courts for some categories of treaties. ${ }^{43}$ But the decisive interests of national uniformity that arise in the context of formal treaty obligations-and that animate the two noted fields of established federal common law-mandate a different, and ultimately more accommodating, calculus for the interstitial lawmaking powers of federal courts within the scope of self-executing treaties. ${ }^{44}$

As Judge Guido Calabresi famously observed, the rapid expansion of federal statutory law in the twentieth century forced a profound reexamination of common law in "this age of statutes." 45 Now, however, with the continuing transition from interstate to international integration, the law is increasingly entering a new phase in its maturation. As the perspective of federal lawmaking changes from internal competition with state authority to external uniformity for the nation's international treaty obligations, a new occasion arises for fundamentally reexamining the role of federal courts in applying federal law as the "supreme Law of the Land." 46

The Force and Significance of the Modern Treaty Power

A. Constitutional Background and Text: The Role of Treaties as Directly Applicable Federal Law

\section{Federal Power, Foreign Affairs, and Treaties}

The authority over foreign affairs in general and treaty making in particular is perhaps the most explicit, detailed, and expansive power that the Constitution delegates to the federal government. Article II, Section 2, of the Constitution expressly grants to the national executive the power to make treaties, "by and with the Advice and Consent of the Senate." 47 Elsewhere, the Constitution confirms the significance of this delegated power, by both granting treaties the preemp-

42 See infra notes 374-83 and accompanying text.
43 See discussion infra Part IV.C.
44 See discussion infra Part IV.B.2.a-b; see also discussion infra Part IV.B.2.c (analyzing the relative error costs associated with decisions regarding the displacement of state law by federal common law under treaties).

45 Guido Calabresi, A Common Law for the Age of Statutes 163 (1982).

46 U.S. Const. art. VI, cl. 2.

47 Id. art. II, $\S 2$, cl. 2 (providing that the President "shall have Power, by and with the Advice and Consent of the Senate, to make Treaties, provided two thirds of the Senators present concur"). 
tive force of federal law ${ }^{48}$ and expressly denying to the states any authority in the field. ${ }^{49}$

The preemptive force of treaties follows directly from their inclusion within the Supremacy Clause of Article VI. ${ }^{50}$ By designating treaties the "supreme Law of the Land," Article VI ensures that the paramount interests of the nation as a whole in matters of international commerce, peace, and diplomacy cannot be frustrated by the parochial interests of the individual states. Indeed, the express reference to treaties in the Supremacy Clause was an immediate result of the international embarrassment arising from the states' failure to adhere to national treaty obligations-particularly those under the 1783 Treaty of Paris with Great Britain-under the Articles of Confederation. ${ }^{51}$ To ensure that there would be no misunderstanding, the Framers expressly declared in Article VI that "the Judges in every State shall be bound" by the terms of treaties, notwithstanding the laws and even the constitutions of the several states. ${ }^{52}$

Departing from its basic model of enumerated federal powers, the Constitution also contains an express prohibition on state power with respect to treaties. Article I, Section 10, provides that "[n] o State shall enter into any Treaty, Alliance, or Confederation." 53 And, lest there be any doubt about terminology, this same section later prohibits states, without the consent of Congress, from concluding "any Agreement or Compact with a foreign Power." 54

The Constitution bolsters the exclusive federal authority over international treaty making by delegating a variety of broader powers over foreign affairs to Congress. Article I, Section 8, for example, grants Congress the power " $[t]$ o regulate Commerce with foreign Na-

48 See id. art. VI, cl. 2 (providing that "all Treaties made, or which shall he made, under the Authority of the United States, shall be the supreme Law of the Land").

49 See id. art. I, $\$ 10, \mathrm{cl}$. 1 (prohibiting the states from entering "into any Treaty, Alliance, or Confederation").

50 See id. art. VI, cl. 2 (providing that "all Treaties made, or which shall be made, under the Authority of the United States, shall be the supreme Law of the Land").

51 See Flaherty, supra note 15, at 2118-19 (explaining that the embarrassment incurred by the states' refusal to give domestic effect to treaty obligations was a prime motivating force for the inclusion of treaties in the Supremacy Clause); Edward T. Swaine, Negotiating Federalism: State Bargaining and the Dormant Treaty Power, 49 Duke L.J. 1127, 1198-99 (2000) (arguing that in light of the "embarrass[ment]" and "material consequences" caused by states' failure to adhere to the terms of treaties such as the 1783 Treaty of Paris, "[t]he Supremacy Clause, together with the Necessary and Proper Clause, was intended to allow the federal government to ensure U.S. compliance with its international obligations").

52 See U.S. Const. art. VI, cl. 2 (providing with regard to the Constitution, laws, and treaties of the United States that "the Judges in every State shall be bound thereby, any Thing in the Constitution or Laws of any State to the Contrary notwithstanding").

53 Id. art. I, $\$ 10$, cl. 1 .

54 See id. art. I, § 10, cl. 3. 
tions," ${ }_{55}$ "[t]o establish an uniform Rule of Naturalization," 56 and to "regulate the Value ... of foreign Coin." 57 This same section also grants Congress authority over the external defense of the country, ${ }^{58}$ the definition and punishment of crimes against international law, ${ }^{59}$ and the declaration of war and other reprisals for international offenses. ${ }^{60}$

Similarly, the Constitution grants to the President, incident to his general executive powers, expansive authority as the international representative of the United States. In addition to the power to make treaties, ${ }^{61}$ Article II, Section 2, designates the President the Commander-in-Chief of the armed forces ${ }^{62}$ and grants him the authority both to appoint ambassadors (again with the advice and consent of the Senate) ${ }^{63}$ and to "receive Ambassadors and other public Ministers." ${ }^{4}$ Moreover, implicit in the President's "'vast share of responsibility for the conduct of our foreign relations" " 65 is the limited power to preempt state law through so-called sole executive agreements, ${ }^{66}$ as the Supreme Court reaffirmed only last term. ${ }^{67}$

$55 I d$. art. I, $\$ 8$, cl. 3 .

$56 I d$. art. I, $\$ 8, \mathrm{cl} .4$.

57 Id. art. I, $\$ 8$, cl. 5 .

58 See id. art. I, $\$ 8, \mathrm{cl} .1$ (granting Congress the power to "provide for the common Defence . . of the United States"); id. art. I, $\$ 8$, cl. 12 (delegating authority to "raise and support Armies"); id. art. I, $\S 8, \mathrm{cl} .13$ (granting authority to "provide and maintain a Navy"); id. art. I, \& 8, cl. 14 (conferring authority to "make Rules for the Government and Regulation of the land and naval Forces").

59 See id. art. I, \$ 8, cl. 10 (granting Congress the power to "define and punish Piracies and Felonies committed on the high Seas, and Offences against the Law of Nations").

60 See id. art. I, § 8, cl. 11 (granting Congress the power to "declare War, grant Letters of Marque and Reprisal, and make Rules concerning Captures on Land and Water"). Article I, Section 8 also grants to Congress the power to impose "Duties, Imposts and Excises," id. art. 1, $\S 8, \mathrm{cl}$. 1 , and Section 10 of the same Article then expressly forbids the states from doing so, except as "absolutely necessary" for inspection purposes, see id. art. I, §10, cl. 2.

61 See supra note 47 and accompanying text.

62 See U.S. Const. art. Il, § 2, cl. 1 ("The President shall be Commander in Chief of the Army and Navy of the United States, and of the Militia of the several States, when called into the actual Service of the United States . . . .").

63 See id. art. II, \$ 2, cl. 2.

$64 I d$. art. Il, $\S 3$.

65 Am. Ins. Ass'n v. Garamendi, 123 S. Ct. 2374, 2386 (2003) (quoting Youngstown Sheet \& Tube Co. v. Sawyer, 343 U.S. 579, 610-11 (1952) (Frankfurter, J., concurring)); see also Sale v. Haitian Ctrs. Council, Inc., 509 U.S. 155, 188 (1993) (obsenving that the President has "unique responsibility" in matters of "foreign and military affairs"); First Nat'l City Bank v. Banco Nacional de Cuba, 406 U.S. 759, 767 (1972) (plurality opinion) (stating that the President has "the lead role . . in foreign policy").

66 See Garamendi, 123 S. Ct. at 2386-87 (holding that "the President has authority to make 'executive agreements' with other countries, requiring no ratification by the Senate or approval by Congress" (citing Dames \& Moore v. Regan, 453 U.S. 654, 679, 682-83 (1981); United States v. Pink, 315 U.S. 203, 223, 230 (1942); United States v. Belmont, 301 U.S. 324, 330-31 (1937))).

67 See id. at 2386-87. 
The combined effect of these various delegations of power over foreign affairs is that the federal government enjoys a breadth of authority in this field far beyond the standard constitutional model of shared lawmaking powers. Indeed, in a variety of rhetorical flourishes throughout its history the Supreme Court has declared that "foreign affairs and international relations [are] matters which the Constitution entrusts solely to the Federal Government," 68 and that "[f] or local interests the several States of the Union exist, but for national purposes, embracing our relations with foreign nations, we are but one people, one nation, one power." 69 Thus, although the precise scope of "dormant" federal powers in the field of foreign relations is subject to some controversy, ${ }^{70}$ the Court has clearly stated that where the federal government has affirmatively exercised its authority to regulate matters of international affairs, the federal policy "is not and cannot be subject to any curtailment or interference on the part of the several states." 71

The Constitution's description of the judicial power in Article III completes the circle on the force of treaties as federal law. Section 2 of Article III provides that "[ $\mathrm{t}]$ he judicial Power shall extend to all Cases, in Law and Equity, arising under . . . Treaties made, or which shall be made" under U.S. authority. ${ }^{72}$ Thus, if a treaty's substance passes directly into federal law, ${ }^{73}$ it becomes the formal responsibility of federal courts to interpret and give effect to the treaty's terms in actual cases and controversies. ${ }^{74}$

68 Zschernig v. Miller, 389 U.S. 429, 436 (1968).

69 Chae Chan Ping v. United States (The Chinese Exclusion Case), 130 U.S. 581, 606 (1889); see also Japan Line Ltd. v. County of Los Angeles, 441 U.S. 434, 449 (1979) (observing that with respect to the Import-Export Clause, the Constitution addressed "the Framers' overriding concern that 'the Federal Government must speak with one voice when regulating commercial relations with foreign governments" (quoting Michelin Tire Corp. v. Wages, 423 U.S. 276, 285 (1976))); United States v. California, 332 U.S. 19, 35 (1947) (" $[\mathrm{P}]$ eace and world commerce are the paramount responsibilities of the nation, rather than an individual state . . . .); United States v. Curtiss-Wright Export Corp., 299 U.S. 304, 317 (1936) ("The Framers' Convention was called and exerted its powers upon the irrefutable postulate that though the states were several their people in respect of foreign affairs were one."); Fong Yue Ting v. United States, 149 U.S. 698, 711 (1893) ("The only government of this country, wbich other nations recognize or treat with, is the government of the Union .... The Constitution of the United States speaks with no uncertain sound upon this subject.").

70 See infra notes 516-17 and accompanying text (discussing the notions of a "dormant foreign affairs power" and a "dormant foreign Commerce Clause").

71 Belmont, 301 U.S. at 331 (citing Curtiss-Wright Export Corp., 299 U.S. at 316).

72 See U.S. Const, art. Ill, \$ 2, cl. 1.

73 See infra notes 82-89 and accompanying text for more detail about this process.

74 See infra notes 87-95 and accompanying text (analyzing federal courts' interpretive authority over treaties in greater detail). 


\section{Treaties and the Self-Execution Doctrine}

The inclusion of treaties in the Supremacy Clause of the Constitution also represented a subtle, but significant, departure from preexisting international practice. In the international sphere, a treaty reflects merely an external contract between sovereigns. The legal character of these contracts derives not from domestic law sources, but rather from the general requirement that nations faithfully adhere to their international obligations (known as pacta sunt servanda). ${ }^{75}$ In other words, treaties obtain their legal force from the reciprocal international obligation of "good faith" performance, irrespective of their effect within the domestic law of the treaty partners. ${ }^{76}$

In many countries, the transformation of international treaty obligations into local law requires an additional legislative act by domestic lawmaking institutions. ${ }^{77}$ In the United States, however, "a different principle is established."78 As the Supreme Court declared in Foster $v$. Neilson, the U.S. Constitution permits treaties to take effect as directly applicable federal law without legislative transformation: "Our Constitution declares a treaty to be the law of the land. It is, consequently, to be regarded in Courts of justice as equivalent to an act of the legislature, whenever it operates of itself without the aid of any legislative provision." 79

Therefore, by virtue of the Supremacy Clause, the President and a supermajority of the Senate-which I have referred to elsewhere as the "treaty-lawmakers" 80 - have the power to promulgate federal law

75 See Restatement (Third) of the Foreign Relations Law of the United States, $\$ 321 \& \mathrm{cmt}$ a (1987) [hereinafter Restatement of Foreign RELATIONs] (referring to the binding force of international law agreements in light of the doctrine of pacta sunt servanda); Louis Henkin, Constitutionalism, Democracy, and Foreign Affairs 62 (1990) (opining that the doctrine of pacta sunt servanda is "the most important principle of international law").

76 See Vienna Convention on the Law of Treaties, opened for signature May 23, 1969, art. 26, 1155 U.N.T.S. 331, 339, available at http://www.un.org/law/ilc/texts/treatfra.htm [hereinafter Vienna Convention on Treaties] ("Every treaty in force is binding upon the parties to it and must be performed by them in good faith."); RESTATEMENT OF FoREIGN Relations, supra note 75, $\$ 321$ ("Every international agreement in force is binding upon the parties to it and must be performed by them in good faith.").

77 As I have noted elsewhere, the more common international approach is to ratify treaties through standard legislation before giving them effect as domestic law. See Van Alstine, supra note 19, at 1265; see also Richard B. Lillich, Invoking International Human Rights Law in Domestic Courts, 54 U. Cin. L. Rev. 367, 373 (1985) (stating that "relatively few countries have adopted the doctrine of self-executing treaties"); Stefan A. Riesenfeld \& Frederick M. Abbott, The Scope of U.S. Senate Control Over the Conclusion and Operation of Treaties, 67 CHI.-Kent L. REV. 571, 575 (1991) (observing that in some countries, "such as the United Kingdom, treaties . . require parliamentary action before the courts will recognize individual rights").

78 Foster v. Neilson, 27 U.S. (2 Pet.) 253, 314 (1829), overruled on other grounds by United States v. Percheman, 32 U.S. (Pet.) 51, 52 (1833).

$79 \quad I d$. at 314.

80 See Van Alstine, supra note 19, at 1286. 
incident to the treaty power of Article $11 .^{81}$ These treaty-lawmakers thus have the constitutional authority to create directly applicable federal law without Article I implementing legislation. ${ }^{82}$ The powerful aspect of such a "self-executing treaty," in other words, is that it operates as federal law even without the involvement of the House of Representatives. Moreover, in confirmation of Foster's description of a treaty as "equivalent to an act of the legislature," ${ }^{33}$ the Supreme Court has repeatedly observed that the Constitution places the provisions of self-executing treaties "in the same category as other laws of Congress," ${ }^{84}$ with the same "force and effect [as] a legislative enactment." 85 Just like any other form of newly enacted federal law, therefore, a self-executing treaty will broadly preempt contrary state law. ${ }^{86}$

Under the Supremacy Clause, federal courts have not only the right, but also the obligation, to enforce the provisions of self-execut-

81 See Golove, supra note 10 , at 1286 ("The treaty power empowers the President and Senate, incident to making agreements with foreign states, to promulgate laws.").

82 See Trans World Airlines, Inc. v. Franklin Mint Corp., 466 U.S. 243, 252 (1984) (describing a self-executing treaty as one for which "no domestic legislation is required to give [it] the force of law in the United States"); Whitney v. Robertson, 124 U.S. 190, 194 (1888) (holding that treaty provisions are self-executing when they "require no legislation to make them operative"); Dainese v. Hale, 91 U.S. 13, 18-19 (1875) ("[A]s treaties made under the authority of the United States are, by the Constitution, declared to be part of the supreme law of the land, when they are complete in themselves, and need no supplemental legislation to carry them into effect, . . legislation is not necessary . . . "); cf. RestateMENT OF Foreign Relations, supra note 75, \$111(4) (stating that if it is otherwise constitutional and the Senate does not attach a corresponding reservation, an international agreement is deemed "non-self-executing" if it "manifests an intention that it shall not become effective as domestic law without the enactment of implementing legislation"). Like other forms of federal law, this self-executing treaty power is subject to other constitutionally protected rights. See infra notes 346-50 and accompanying text.

8327 U.S. (2 Pet.) at 314.

84 The Head Money Cases, 112 U.S. 580, 598 (1884); see also, e.g., Fellows v. Blacksmith, 60 U.S. (19 How.) 366,372 (1856) ("[A] treaty ... becomes the supreme law of the land, and the courts can no more go behind it for the purpose of annulling its effect and operation, than they can behind an act of Congress."); United States v. Schooner Peggy, 5 U.S. (1 Cranch) 103, 110 (1801) ("[W]here a treaty is the law of the land, and as such affects the rights of parties litigating in court, that treaty as much binds those rights and is as much to be regarded by the court as an act of congress....").

85 Whitney, 124 U.S. at 194; see also, e.g., Valentine v. United States ex rel. Neidecker, 299 U.S. 5, 10 (1936) (holding that a treaty is "equivalent to an act of the legislature" (quoting Foster v. Neilson, 27 U.S. (2 Pet.) 253, 314 (1829), overruled on other grounds by United States v. Percheman, 32 U.S. (Pet.) 51, 52 (1833))); United States v. Forty-Three Gallons of Whiskey, 93 U.S. 188, 196 (1876) (same).

86 See De Canas v. Bica, 424 U.S. 351,357 n.5 (1976) (concluding that even without an "intent to 'occupy the field,' the Supremacy Clause requires the invalidation of any state legislation that burdens or conflicts in any manner with any . . treaties"); Hines v. Davidowitz, 312 U.S. 52, 62-63 (1941) ("When the national government by treaty . . . has established rules and regulations ... the treaty ... is the supreme law of the land. No state can add to or take from the force and effect of such treaty ...."). 
ing treaties ${ }^{87}$ Indeed, as the Supreme Court recently confirmed in a controversial case involving a kidnapping by federal officials in a foreign country, if a treaty is self-executing, a court must enforce it on behalf of an individual "regardless of the offensiveness of the practice of one nation to the other nation." 88 And this applies as much to actions in state courts as it does to other federal institutions, as has been clear since at least 1816, when the Supreme Court decided the famous case of Martin v. Hunter's Lessee. 89

The doctrine of self-execution does not mean that every provision of every treaty automatically creates federal rights or obligations. Similar to other forms of federal law, ${ }^{90}$ the treaty-lawmakers may expressly provide that a particular treaty is not self-executing-a circumstance that has become quite common in the special category of aspirational human rights treaties. ${ }^{91}$ Such a provision leaves the decision on transformation into enforceable federal law to Congress. Similarly, other treaties, as Professor Carlos Manuel Vázquez has explained, may be

87 See Carlos Manuel Vázquez, Treaty-Based Rights and Remedies of Individuals, 92 Colum. L. Rev. 1082, 1108 (1992). But cf. Yoo, Non-Self-Execution, supra note 14, at 1978-80 (arguing that judicial enforceability of treaties does not necessarily follow from their "law of the land" status).

88 United States v. Alvarez-Machain, 504 U.S. 655, 667 (1992).

8914 U.S. (1 Wheat.) 304, 347-60 (1816). Although easily overlooked, Martin concerned a treaty's effect on individual property rights. See id. at 305-13. The case arose after the Supreme Court of Virginia refused to follow the federal Supreme Court's enforcement of treaty rights in an earlier case. See Fairfax's Devisee v. Hunter's Lessee, 11 U.S. (7 Cranch) 603, 627 (1812) (holding in a land dispute that a treaty "being the supreme law of the land, confirmed the title to [Fairfax], his heirs and assigns, and protected him from any forfeiture by reason of alienage" under state law). In declaring that it was the final authority on the interpretation and application of federal law, the Supreme Court in Martin famously observed:

Judges of equal learning and integrity, in different states, might differently interpret a statute, or a treaty of the United States, or even the [C]onstitution itself: If there were no revising authority to control these jarring and discordant judgments, and harmonize them into uniformity, the laws, the treaties, and the [C]onstitution of the United States would be different in different states, and might, perhaps, never have precisely the same construction, obligation, or efficacy, in any two states.

14 U.S. (1 Wheat.) at 348.

90 For instance, Congress often delegates to administrative agencies the discretion to adopt implementing regulations. Although the statutory authorization qualifies as federal law for purposes of the Supremacy Clause, it does not directly create enforceable individual rights. Rather, the discretion concerning the timing and precise content of the rights is delegated to the administrative agency. See Chevron U.S.A., Inc. v. Natural Res. Def. Council, 467 U.S. 837, 843-44 (1984) (holding that where "Congress has explicitly left a gap for the agency to fill, there is an express delegation of authority to the agency to elucidate a specific provision of the statute by regulation. Such legislative regulations are given controlling weight unless they are arbitrary, capricious, or manifestly contrary to the statute").

91 See Bradley \& Goldsmith, supra note 10, at 403-23, 439-67 (describing the role of such reservations and defending their constitutionality). 
merely precatory, ${ }^{92}$ or otherwise touch so closely on political issues that courts properly refrain from exercising jurisdiction in the absence of express guidance. ${ }^{93}$ Still other treaties may not be amenable to affirmative enforcement by individuals because they do not confer a private right of action. ${ }^{94}$

When a treaty reflects an intent to create rights or obligations of its own accord, however, Article III mandates that federal courts apply it as a federal rule of decision, just as they would a statute or other form of enforceable federal law. The scope of this "judicial Power" of federal courts in relation to treaties will of course be a core concern in the analysis below. ${ }^{95}$ But before we can examine the lawmaking powers of federal courts under treaties, it is first necessary to clear away some of the remaining underbrush of scholarly controversy over the very constitutionality of self-executing treaties.

\section{B. Responding to the Revisionist Challenge to Self-Execution}

\section{The Challenge and the Historical Debate}

As the significance of treaties has expanded both in substantive scope and in society's political consciousness, virtually every aspect of treaty law has become the subject of heated scholarly debates. ${ }^{96}$ Professor John Yoo has now extended the controversy to include the very notion of a self-executing treaty. As a foundation for his attack on self-executing treaties, Professor Yoo cites the international understanding (especially in Great Britain) of the effect of treaties before the Framers adopted the Constitution, and scattered statements during the Constitutional Convention, in particular various arguments advanced in some states' ratification debates. ${ }^{97}$ Principally from these historical sources, he concludes that the Constitution prohibits judicial enforcement of a treaty within the scope of Congress's Article I legislative powers without implementing legislation. ${ }^{98}$

92 See Carlos Manuel Vázquez, The Four Doctrines of Self-Executing Treaties, 89 AM. J. INT'L L. 695, 713-15 (1995) [hereinafter Vázquez, Four Doctrines]; Vázquez, supra note 87, at 1130-33; see also INS v. Cardoza-Fonseca, 480 U.S. 421, 441 (1987) (observing that provisions in the United Nations protocol relating to the status of refugees are merely precatory); Sei Fujii v. California, 242 P.2d 617, 619-22 (1952) (concluding that certain provisions of the United Nations Charter were too vague to be self-executing).

93 See Vázquez, Four Doctrines, supra note 92, at 717 (citing arms control agreements as examples of treaties that may not be "judicially enforceable under our Constitution because they bear too closely on national security or are otherwise too sensitive for judicial involvement").

94 See id. at $719-21$.

95 See discussion infra Part III.A.

96 See supra notes 12-19 and accompanying text (describing the variety of controversies over the treaty power).

97 See Yoo, Non-Self-Execution, supra note 14, at 1982-2074.

98 See id. at 2092-94 (setting forth the conclusion of his historical analysis); see also Yoo, Treaties and Public Lawmaking, supra note 14, at 2220 (describing the approach as a 
This account of some hidden, extratextual limitation on the treaty power is unconvincing. From a textual perspective, the Supremacy Clause contains no ambiguity: "[A]ll Treaties . . . shall be the supreme Law of the Land." 99 Moreover, as Professor Vázquez has persuasively argued, ${ }^{100}$ this reference to treaties appears in the same sentence that defines the effect of other well-accepted and uncontroversial forms of direct federal law: the "Constitution and the laws of the United States."101 Thus, Article VI, Clause 2 leaves no textual room to argue that treaties are any less the "supreme Law of the Land" than these other forms of federal law. ${ }^{102}$

In addition, Article III's description of the constitutional role of federal courts precludes any serious challenge to self-executing treaties. Article III, Section 2 expressly provides that the judicial power of the federal courts extends to all cases "arising under ... Treaties." 103 If Professor Yoo's account is correct, the reference to treaties in this constitutional provision would be entirely superfluous. If Article I legislation is required to give a treaty effect under domestic law in any event, then no case could "aris[e] under" a treaty itself.

" "hard' rule" under which " $[\mathrm{t}]$ reaties cannot receive judicial enforcement in areas that fall within Congress's Article I, Section 8 powers, without statutory implementation by Congress"). This conclusion, ironically, is in large measure the direct logical opposite stance of the other principaI critic of an expansive treaty power, Professor Curtis Bradley. Relying principaIly on federalism concerns, Professor Bradley argues that self-executing treaties are subject to the same substantive limitations as Congress's Article I legislative powers. See Bradley, Treaty Power, supra note I3, at 456-61. Professor Yoo, in contrast, argues that a self-executing treaty may not regulate matters within Congress's Article I legislative powers at all. See Yoo, Non-Self-Execution, supra note 14, at 2092-94.

99 See supra note 4 and accompanying text.

100 See Vázquez, supra note I5, at 2170 (arguing, in response to the contention that treaties require a further Iegislative act before they constitute federal law, that " $[t]$ he words 'shall be' in the Supremacy Clause apply equally to the Constitution and federal statutes, yet the clause has always been read to make the Constitution and federal statutes the supreme law of the land immediately upon their coming into force").

101 U.S. CONST. art. VI, cl. 2.

102 As an alternative to a prohibition on self-executing treaties, Professor Yoo has suggested a "soft rule" pursuant to which courts would apply a presumption against self-execution. See Yoo, Non-Self-Execution, supra note 14, at 2093; Yoo, Treaties and Public Lawmaking, supra note 14, at 2220 (describing the approach as a rule in which "courts can remain true to the text, structure, and original understanding of the Constitution by requiring the treatymakers to issue a clear statement if they want a treaty to be self-executing"). One court, in fact, has embraced a similar approach, although it nowhere explains the constitutional foundation for such a presumption with respect to formal private causes of action. See United States v. Li, 206 F.3d 56, 60-61 (1st Cir. 2000) (holding that there is a "presumption against private rights of action under international treaties"). But see Vázquez, supra note 15, at 2214-15 (rejecting even this "soft rule" approach as contrary to the text of the Supremacy Clause, as well as Supreme Court precedent on self-executing treaties).

103 U.S. Const, art. III, $§ 2$, cl. 1 ("The judicial Power shall extend to all Cases, in Law and Equity, arising under . . . Treaties made, or which shall be made," under U.S. authority). 
The attack on the self-execution doctrine is thus diminished to the assertion that historical sources somehow create a lasting interpretive radiation that dissolves the explicit text of Article VI, Clause 2, and Article III, Section 2. But even here, Professor Martin Flaherty has comprehensively and convincingly demonstrated that historical sources are entirely consistent with the notion of self-executing treaties. ${ }^{104}$ Professor Flaherty's analysis reveals that the framers intended the Constitution to depart from prior eighteenth century thought and practice on treaties, ${ }^{105}$ and that the clear weight of historical evidence from the Constitutional Convention ${ }^{106}$ and from the "critical period" immediately preceding and succeeding ratification ${ }^{107}$ confirms the intent to grant treaties direct effect as federal law. In other words, his analysis demonstrates that-not surprisingly-the historical sources confirm what the text of Articles III and VI unambiguously provides. ${ }^{108}$ In short, the thin collection of historical references gathered

104 See Flaherty, supra note 15, at 2099-2151.

105 See id. at 2112-26. Indeed, the federal government's power to conclude treaties with direct effect as federal law preceded even the Constitution. The Articles of Confederation granted this power-although subject to a different process and in a more limited form-to the federal congress. See Golove, supra note 10, at 1108-15 (concluding that, although their precise effect on state law was ambiguous, the Articles of Confederation granted the federal congress the power to conclude treaties that directly regulated private rights and obligations).

106 See Flaherty, supra note 15, at 2120-26. As Professor Flaherty also notes, we need not even speculate about any hidden intentions of the framers of the Constitution. During the drafting of the Convention, one delegate, Gouverneur Morris, proposed an amendment to strike as superfluous a proposed constitutional provision that granted Congress power to enforce treaties, because "'treaties were to be laws. . . '” Id. at 2124 (quoting 2 Records of the Federal Convention of 1787, at 389-90 (Max Farrand ed., 1911) (emphasis added)). Gouverneur Morris also proposed an amendment that would have expressly required all treaties to be "ratified by a Law" pursuant to Article I. The records reveal that this amendment was decisively defeated. See Jack N. Rakove, Solving a Constitutional Puzzle: The Treatymaking Clause as a Case Study, 1 Persp. AM. HIst. 233, 241 (1984) (ohserving that after the defeat of a broader motion to postpone debate on the treaty clause, "the Convention immediately rejected Morris's amendment decisively"). A similar proposal by James Wilson two weeks later to include the House of Representatives in the treaty approval process met the same fate. See Flaherty, supra note 15, at 2123-24 (recounting the defeat of the Wilson proposal during the Constitutional Convention and observing that "we do not need to rely on inference" to discern to the intent of the framers on this score); Rakove, supra, at 246 (observing that Wilson's proposal "was decisively rejected"). Professor Yoo himself acknowledges the significance of the defeat of these proposed constitutional limitations for the domestic law effect of treaties. See Yoo, Non-Self-Execution, supra note 14, at 2033-34; see also Golove, supra note 10, at 1134-36 (descrihing the rejection during the Constitutional Convention of states rights-based attempts to limit the domestic effect of treaties).

107 See Flaherty, supra note 15, at 2126-51.

108 As summarized by the leading historical scholar on the treaty power, the historical evidence leaves little doubt about self-executing treaties: "Whatever uncertainty might have persisted about the precise allocation of the authority to make treaties, the framers were virtually of one mind when it came to giving treaties the status of law." Rakove, supra note 106, at 264 (observing that "[ $\mathrm{t}$ ] he major consequence" of the need to make treaties legally binding on the states "was the ready adoption of the supremacy clause, which gave treaties 
by Professor Yoo, although seemingly comprehensive, does not support the weighty conclusion he draws against self-executing treaties, especially in the face of clear constitutional text to the contrary.

Even if the constitutional text were ambiguous, resolution of the issue would not depend solely on examining the residue of distant rhetorical debates. The immediate post-ratification actions of the constitutional institutions established in 1789 speak with significantly greater force and clarity. These formal actions of Congress and the President provide further support for the conclusion that the collective contemporaneous understanding was that treaties could have direct effect as federal law. Because commentators have not subjected these actions to detailed exploration, the next section analyzes them as a necessary backdrop to the role of self-executing treaties in our domestic legal landscape.

\section{Confirmation Through Action: The Post-Ratification Conduct of the Political Branches on Self-Execution}

From the first exercises of its new constitutional powers, Congress expressly recognized the force of treaties as directly applicable federal law. 1ndeed, the First Congress's most significant piece of legislation, the Judiciary Act of 1789,109 repeatedly acknowledged that treaties could create rights that were cognizable before federal courts. Section 25 of that Act, for instance, provided that the appellate jurisdiction of the Supreme Court extended to cases involving "the validity of a statute of, or an authority exercised under any State, on the ground of their being repugnant to . . . treaties ... of the United States." 110

In a later clause of the same section, the First Congress made clear that treaties could create individual rights. Section 25 provided that whenever a lower court's "construction of any clause ... of a treaty . . . is against the title, right, privilege or exemption specially set up or claimed by either party, under such clause of the said . . . treaty ... . [the lower court's decision] may be re-examined and reversed or affirmed in the Supreme Court of the United States . ..."111 Underlying this jurisdictional statute is the unambiguous recognition that a treaty could create an individual "title, right, privilege or exemption" in the first place.

The First Congress was equally clear in its identification of the substantive law that federal courts must apply. In the first Rules of

the status of law and made them judicially enforceable through the federal courts"); see also Flaherty, supra note 15, at 2120-26 (discussing Professor Rakove's observations and the contextual historical evidence in greater detail).

109 Ch. 20, 1 Stat. 73 (1789) (codified in scattered sections of 28 U.S.C.).

$110 \quad I d . \$ 25,1$ Stat. at 85.

111 Id. $\$ 25,1$ Stat. at 85-86. 
Decision Act-which plays a prominent role in the analysis of federal common law below 12 -Congress provided that the substantive law of the States would apply "except where the [C]onstitution, treaties or statutes of the United States shall otherwise require or provide." 113 Here again, the nation's first legislature affirmed that federal law may come into being through treaties just as through the Constitution and Article I laws. Similarly, in the initial version of the (now highly controversial114) Alien Tort Claims Act in 1789, the First Congress provided that the jurisdiction of the new district courts would extend to "all causes where an alien sues for a tort only in violation of ... a treaty of the United States."115

The first legislators under the new Constitution continued to affirm the principle of self-executing treaties throughout the first decade of the Constitution's existence. In a 1790 Act "to regulate trade and intercourse with the Indian tribes," for example, Congress prohibited the sale of Native American land within the United States "unless the same shall be made and duly executed at some public treaty ... under the authority of the United States."116 Note that here again the Act does not mention any requirement that such a treaty receive statutory confirmation before taking effect as federal law. Congress passed similar legislation in I793, ${ }^{117} 1796,{ }^{118}$ and I799. ${ }^{119} \mathrm{~A}$ recognition that treaties could create federal rights also emerged

\footnotetext{
112 See infra notes 214-16, 394-96, and 429-30 and accompanying text.

113 The Judiciary Act of $1789 \S 34,1$ Stat. at 92 .

114 See, e.g., Peter Schuyler Black, Kadic v. Karadzic: Misinterpreting the Alien Tort Claims
} Act, 31 GA. L. REv. 281, 322 (1996) ("The mysterious background of the [Alien Tort Claims Act] has left courts struggling to interpret it. Originally enacted to bestow jurisdiction over special cases in the law of prize, the [Act] is now used primarily to allow United States federal courts to hear international human rights cases."); Terry Collingsworth, Separating Fact from Fiction in the Debate over the Application of The Alien Tort Claims Act to Violations of Fundamental Human Rights by Corporations, 37 U.S.F. L. REv. 563, 564 (2003) ("The prospect of facing scrutiny for human rights violations, and possibly having to pay large damage awards, has alarmed the international business community, which has declared war on the [Alien Tort Claims Act]."); Justin Lu, Jurisdiction over Non-State Activity under the Alien Tort Claims Act, 35 Colum. J. Transnat'L L. 531, 546-48 (1997) (recognizing the difficulties in applying the Alien Tort Claims Act and criticizing the Second Circuit Court of Appeals for erroneously expanding the Act's scope).

115 The Judiciary Act of $1789 \$ 9$ (c), 1 Stat. at 77.

116 An Act to Regulate Trade and Intercourse with the lndian Tribes, ch. 33, $\S 4,1$ Stat. 137, 138 (1790).

117 See An Act to Regulate Trade and Intercourse with the Indian Tribes, ch. 19, § 8, 1 Stat. 329, 330 (1793) (invalidating any "purchase or grant of lands, or of any title or claim thereto ... unless ... made by a treaty or convention entered into pursuant to the constitution").

118 See An Act to Regulate Trade and Intercourse with the Indian Tribes, and to Preserve Peace on the Frontiers, ch. 30, $\$ 12,1$ Stat. 469, 472 (1796) (providing that Native Americans may dispose of their land only througb a treaty).

119 See An Act to Regulate Trade and Intercourse with the Indian Tribes, and to Preserve Peace on the Frontiers, ch. 46, $§ 12,1$ Stat. 743, 746 (1799) (same). 
from legislation adopted in 1797 in connection with the Treaty of Amity, Commerce and Navigation Between the United States and Great Britain. ${ }^{120}$

All of these legislative acts occurred, of course, with the involvement of a Senate. At the time, significantly, this body was (and until 1913 remained) composed of directly appointed representatives of the state legislatures. ${ }^{121}$ Likewise, from the first exercises of its "Advice and Consent" power, ${ }^{122}$ the Senate repeatedly approved of treaties with self-executing provisions-including after the Supreme Court itself repeatedly confirmed the force of treaties as federal law (discussed in greater detail below ${ }^{123}$ ). In July 1789 , for example, the Senate consented to a consular treaty with France-negotiated even before the ratification of the Constitution ${ }^{124}$-which, among other self-executing provisions, directly gave individual French citizens the right to assert claims in state courts. ${ }^{125}$ Other treaties endorsed by the Senate in the first decade of its existence contained similar terms. ${ }^{126}$

120 See An Act Directing the Appointment of Agents, in Relation to the Sixth Article of the Treaty of Amity, Commerce and Navigation, Between the United States and Great Britain, ch. $6, \S 1,1$ Stat. 523, 523 (1797). In that statute, Congress made appointments to a commission whose sole purpose was to adjudicate claims based on individual rights protected by the treaty.

121 Until the Seventeenth Amendment, which took effect in 1913, U.S. senators were chosen by the legislatures of each state, not by direct election by the people. See U.S. Const, art. I, $\S 3$, cl. 1, amended by U.S. ConsT, amend. XVI, $\$ 1$.

122 U.S. Consr. art. II, § 2.

123 See infra notes $133-43$ and accompanying text.

124 The Supremacy Clause makes clear that treaties concluded before the Constitution likewise operate as the "supreme Law of the Land." See U.S. ConsT. art. VI, cl. 2 (using the past tense in providing that "all Treaties made ... under the Authority of the United States" shall be the supreme law of the land); Chirac v. Chirac's Lessee, 15 U.S. (2 Wheat.) 259,271 (1817) (holding with regard to a 1778 treaty with France that “ [i]t is unnecessary to inquire in to the effect of this treaty under the confederation, because . . . the confederation had yielded to our present constitution, and this treaty had become the supreme law of the land").

125 See Convention Between His Most Christian Majesty and the United States of America, for the Purpose of Defining and Establishing the Functions and Privileges of Consuls and Vice Consuls, Nov, 14, 1788, Fr.-U.S., art. 6, 8 Stat. 106, 110, in 2 TREATIES AND Other International Acts of the United States of America 234 (Hunter Miller ed., 1931) [hereinafter Treaties and Other 1NTERnational. Acts].

126 A 1795 treaty with Spain, for instance, expressly protected the right of Spanish citizens "to dispose of their personal goods" in the United States. See Treaty of Friendship, Limits and Navigation, Oct. 27, 1795, U.S.-Spain, art. 11, 8 Stat. 138, 144, in Treaties AND OTHER lNTERNATIONAL ACTS, supra note 125, at 326. A series of similar treaties with the socalled Barbary States of Northern Africa also protected the navigation rights of citizens of the treaty partners. See, e.g., Treaty of Peace and Amity, Sept. 5, 1795, Alg.-U.S., art. 3, 8 Stat. 133, 133, in Treaties AND OTHER INTERnATIONAL ACTS, supra note 125, at 299 ("[A]ll Goods monies or Passengers of whatsoever Nation that may be on board of the Vessels belonging to either Party Shall be considered as inviolable and shall be allowed to pass unmolested"); Treaty of Peace and Friendship Between the United States of America and the Bey and Subjects of Tripoli of Barbary, Nov. 4, 1796, U.S.-Tripoli, art. 7, 8 Stat. 154, 154, in Treaties and Other International Acts, supra note 125, at 365 ("Should a vessel of either party be cast on the shore of the other, all proper assistance shall be given to her 
The Senate even consented in 1796 to the highly controversial "Jay Treaty" with Great Britain. ${ }^{127}$ This treaty precipitated substantial and impassioned rhetoric-but ultimate acquiescence-by states' rights advocates in the House of Representatives precisely because of selfexecuting provisions on the rights of British subjects in the United States. ${ }^{28}$

The immediate post-ratification actions of the President also confirmed the understanding of the constitutional effect of treaties. Each of the above-noted legislative acts-in the first decade of the Constitution-became federal law with the approval of President Washington. ${ }^{129}$ Moreover, for each of these self-executing treaties, the executive branch conducted the negotiations and deposited the postconsent instruments of ratification. ${ }^{130}$ Like the laws passed in the early Houses of Representatives and Senates, the actions of the executive branch in the years immediately following ratification confirmed that treaties did not require implementing legislation to take direct effect as federal law.

\section{Confirmation Through Jurisprudence: Supreme Court Precedent and Self-Execution}

Even if one were to leave aside the acts of the political branches, any challenge to the doctrine of self-execution would face another formidable obstacle: From its first confrontations with the issue, the Supreme Court has shown no discernible doubt about the proposition that treaties operate of their own force as federal law when their substance so directs. Commentators have not yet sufficiently appreciated, however, the clarity, consistency, and sheer volume of Supreme Court jurisprudence on this score.

and her people; no pillage shall be allowed; the property shall remain at the disposition of the owners, ..."); Treaty of Peace and Friendship, Aug. 28, 1797, U.S.-Tunis., art. 8, 8 Stat. 157, 158, in Treaties AND OTHER INTERNATIONAL ACts, supra note 125, at 405 (signed with alterations, Mar. 26, 1799) (establishing reciprocal rights of the citizens of the contracting states, including rights to "the same respect . . . which the merchants of other nations enjoy" and the right "to establish themselves within [the other nation's] ports" without opposition).

127 See Treaty of Amity[,] Commerce and Navigation [, B]etween His Britannick Majesty;-and [t] he United States of America, hy Their President, with the [A]dvice and [C]onsent of Their Senate, Nov. 19, 1794, Gr. Brit.-U.S., 8 Stat. 116, 116-32, in Treaties AND OTHER INTERNATIONAL AGTS, supra note 125, at 245-74.

128 For a detailed and convincing historical review of the debates over the Jay Treaty, including the acquiescence by Republican opponents in the House of Representatives, see Golove, supra note 10 , at 1157-78.

129 None of the First Congress's noted legislation was adopted over the veto of President Washington.

130 1t became established practice shortly after the ratification of the Constitution for the executive branch to negotiate treaties without formal congressional participation. See Yoo, supra note 18, at 895-901. 
The 1829 opinion in Foster $v$. Neilson ${ }^{131}$ is often taken as the Supreme Court's prime declaration on the legal character of treaties. ${ }^{132}$ A careful review of earlier Court opinions nonetheless reveals that the doctrine of self-execution had already solidified long before that important decision. Within a few short years after the ratification of the Constitution, the Court, applying the Supremacy Clause, interpreted treaties as directly applicable federal law. The Court's 1796 observation in Ware v. Hylton ${ }^{133}$ that the 1783 Treaty of Peace with Great Britain of its own force "nullified" contrary state laws ${ }^{134}$ is well known. ${ }^{135}$ But even as early as 1794, the Court had already established the same rule in Georgia v. Brailsford.136 There, the Court observed-while instructing a jury in the only Supreme Court case of its kind ${ }^{137}$-that state legislation would be invalid to the extent it was "in direct opposition" to rights protected by the 1783 treaty with Great Britain. ${ }^{138}$

In nearly two dozen opinions in the early 1800 s, the Court likewise repeatedly analyzed treaties as directly applicable federal law. ${ }^{139}$

13127 U.S. (2 Pet.) 253 (1829).

132 See, e.g., James A.R. Nafziger \& Edward M. Wise, The Status in United States Law of Security Council Resolutions Under Chapter VII of the United Nations Charter, 46 Aм. J. CoMP. L. Supp. 421, 423 n.13 (1998) (referring to Foster as the "classic statement" that self-executing treaties are binding as domestic law); John M. Raymond \& Barbara J. Frischholz, Lawyers Who Established International Law in the United States, 1776-1914, 76 AM. J. INT'L L. 802, 805 (describing Foster as one of the decisions that "settled in our domestic law important effects of national conventional law established by our treaties"); Vázquez, Four Doctrines, supra note 92 , at 700 ("The distinction between self-executing and non-self-executing treaties was introduced into U.S. jurisprudence by the Supreme Court in Foster $v$. Neilson."); Vázquez, supra note 15, at 2181 (recognizing the treaty in Foster as the "prototype" of a non-selfexecuting treaty).

1333 U.S. (3 Dall.) 199 (1796).

134 See id. at 235-39.

135 See, e.g., Yoo, Non-Self-Execution, supra note 14, at 2075-80 (noting, but attempting to discount the effect of, Ware v. Hylton); see also Vázquez, supra note 15, at 2196-98 (analyzing the force of Ware both generally and in response to Professor Yoo's arguments).

1363 U.S. (3 Dall.) 1 (1794).

137 See Daniel D. Blinka, "This Germ of Rottedness": Federal Trials in the New Republic, 1789-1807, 36 Creichton L. Rev. 135, 163-64 (2003) (discussing this aspect of the Brailsford opinion).

138 See Brailsford, 3 U.S. (3 Dall.) at 5 (observing that even if an act of the State of Georgia confiscated a debt, the Treaty of Peace with Great Britain nonetheless directly restored the related rights to the original British creditor, because the state legislation would be "in direct opposition to the Fourth Article of that Treaty").

139 See, e.g., Am. Ins. Co. v. 356 Bales of Cotton, 26 U.S. (1 Pet.) 511, 542 (1828) (stating that the treaty between the United States and Spain, wherein Spain ceded Florida to the United States, "is the law of the land, and admits the inhabitants of Florida to the enjoyment of the privileges, rights, and immunities, of the citizens of the United States"); Carneal v. Banks, 23 U.S. (10 Wheat.) 181, 189 (1825) (same, applying a 1778 treaty between the United States and France); Hughes v. Edwards, 22 U.S. (9 Wheat.) 489, 496 (1824) (applying the Treaty of Peace between the United States and Britain to override Kentucky state law); Soc'y for Propagation of the Gospel in Foreign Parts v. Town of New Haven, 21 U.S. (8 Wheat.) 464, 489-92 (1823) (applying the Treaty of Peace between the United States and Britain to corporations, thereby overruling Vermont law); Blight's Lessee v. Rochester, 20 U.S. (7 Wheat.) 535, 544-45 (1822) (stating that the Treaty of 
lndeed, by 1801 - only twelve years after ratification of the Constitution and over a quarter century before Foster-the Court in United States v. Schooner Peggy already spoke of the federal courts' "obligation" to give effect to the individual rights established by treaty:

The constitution of the United States declares a treaty to be the supreme law of the land. Of consequence its obligation on the courts of the United States must be admitted .... [W] here a treaty is the law of the land, and as such affects the rights of parties litigating in court, that treaty as much binds those rights and is as much to be regarded by the court as an act of $[\mathrm{C}]$ ongress . . . ${ }^{140}$

Considered in this light, Foster merely represents a concise summary of what was already established precedent. In any event, in the more than 175 years since Foster, the Supreme Court has never discernibly wavered from the proposition that treaties may operate as supreme federal law. Indeed, comprehensive research reveals well over 250 opinions in which the Court alone has interpreted and applied

Peace between the United States and Britain would protect British subjects, even in contravention of estate law, if applicable); The Santissima Trinidad, 20 U.S. (7 Wheat.) 283, 346-47 (1822) (applying a treaty with Spain as U.S. law); The Amiable Isabella, 19 U.S. (6 Wheat.) 1, 68 (1821) (describing a treaty between the United States and Spain as "a treaty which we are bound to observe with the most scrupulous good faith . . . and which this Court could not disregard without betraying its duty"); Orr v. Hodgson, 17 U.S. (4 Wheat.) 453,460 (1819) (holding that aliens could not inherit property in Virginia "unless their disability is removed by the treaty of 1794 "); Chirac v. Chirac's Lessee, 15 U.S. (2 Wheat.) 259, 275 (1817) (overturning Maryland law in favor of a treaty between the United States and France); The Pizarro, 15 U.S. (2 Wheat.) 227, 245-47 (1817) (interpreting treaty language as it applied to the rights of the parties without resort to state law); Martin v. Hunter's Lessee, 14 U.S. (1 Wheat.) 304, 348 (1816) (reasoning that because states might interpret a treaty differently, the Supreme Court must have the "authority to control these jarring and discordant judgments, and harmonize them into uniformity"); Harden $v$. Fisher, 14 U.S. (1 Wheat.) 300, 301 (1816) (stating the rule that British subjects "are incapable of maintaining an action for real estate in the state of New-York, unless they are enabled to do so by ... treaty between the United States and Great Britain"); The Nereide, Bennett, Master, 13 U.S. (9 Cranch) 388, 421 (1815) (examining treaties in order to ascertain U.S. law with regard to a principle of international law); Fairfax's Devisee v. Hunter's Lessee, 11 U.S. (7 Cranch) 603, 627 (1812) (holding that a Virginia law vesting British estates completely with the state or its grantee "has by the operation of the treaty [between the United States and Britain] become ineffectual and void"); Owings v. Norwood's Lessee, 9 U.S. (5 Cranch) 344, 348 (1809) ("Whenever a right grows out of, or is protected by, a treaty, it is sanctioned against all the laws and judicial decisions of the states ...."); Higginson v. Mein, 8 U.S. (4 Cranch) 415, 418-19 (1808) (ruling that the Treaty of Peace between the United States and Britain overrides a Georgia state act confiscating estates of British subjects); Fitzsimmons v. Newport Ins. Co., 8 U.S. (4 Cranch) 185, 199 (1808) (declaring that a treaty between the United States and Britain "constitute[s] a rule in ... place of [the law of nations]"); Hopkirk v. Bell, 7 U.S. (3 Cranch) 454, 458 (1806) (holding that the Treaty of Peace between the United States and Britain overrides a Virginia state act that limited actions to collect debt payment); United States v. Schooner Peggy, 5 U.S. (1 Cranch) 103,110 (1801) ("[W] here a treaty is the law of the land, and as such affects the rights of parties litigating in court, that treaty as much binds those rights and is as much to be regarded by the court as an act of [C]ongress ....").

1405 U.S. (1 Cranch) at 109-10. 
treaties as directly applicable federal law. ${ }^{141}$ Dozens of these opinions expressly confirm that self-executing treaties represent the rule of decision for individual rights in federal courts, just like Article I legislation. ${ }^{142}$ Carrying forward its pronouncement in Schooner Peggy, the Court has likewise consistently affirmed that courts have not only the ability, but the "obligation," to give direct effect to individual rights that a self-executing treaty establishes. ${ }^{143}$

It is appropriate to conclude here with a modern-day application of this two-centuries-old precedent. In the 2000 case of Cheung $v$. United States, the Second Circuit confronted the argument that enforcement of an extradition treaty "would threaten our system of separation of powers." 144 Because it takes effect as law without the participation of the House of Representatives, the petitioner argued, such a self-executing treaty "amount[s] to usurpation of Congress's constitutionally vested legislative authority." 145 The Second Circuit re-

141 A list of these Supreme Court opinions is on file with the author.

142 See, e.g., Chae Chan Ping v. United States (The Chinese Exclusion Case), 130 U.S. 581,600 (1889) ("[T] reaties made under the authority of the United States are . . the supreme law of the land .... If the treaty operates by its own force, and relates to a subject within the power of Congress, it can be deemed in that particular only the equivalent of a legislative act .... ."); Whitney v. Robertson, 124 U.S. 190, 194 (1888) (declaring that where treaty provisions "are self-executing, that is, require no legislation to make them operative[,] . . . they have the force and effect of a legislative enactment"); The Head Money Cases, 112 U.S. 580, 598-99 (1884) (holding that self-executing provisions of treaties may "partake of the nature of municipal law, and ... [ $\mathrm{t}]$ he Constitution of the United States places such provisions as these in the same category as other laws of Congress" and further holding that "when such rights are of a nature to be enforced in a court of justice, that court resorts to the treaty for a rule of decision for the case before it as it would to a statute"); Haver v. Yaker, 76 U.S. (9 Wall.) 32, 35 (1869) ("In this country, a treaty is something more than a contract, for the Federal Constitution declares it to be the law of the land."); Strother v. Lucas, 37 U.S. (12 Pet.) 410,438 (1838) ("Treaties are the law of the land, and a rule of decision in all courts."); Foster v. Neilson, 27 U.S. (2 Pet.) 253, 314 (1829) (observing that a treaty is "to be regarded in Courts of justice as equivalent to an act of the legislature, whenever it operates of itself without the aid of any legislative provision"), overruled on other grounds by United States v. Percheman, 32 U.S. (Pet.) 51, 52 (1833); Am. Ins. Co., 26 U.S. (1 Pet.) at 542 (holding with regard to the treaty that ceded Florida from Spain to the United States that "[ $t]$ his treaty is the law of the land, and admits the inhabitants of Florida to the enjoyment of the privileges, rights, and immunities, of the citizens of the United States"); Chirac, 15 U.S. (2 Wheat.) at 271 (observing that because of the Supremacy Clause even a treaty concluded under the Articles of Confederation "had become the supreme law of the land").

143 See, e.g., United States v. Alvarez-Machain, 504 U.S. 655, 667 (1992) (observing that if a treaty is self-executing "it would appear that a court must enforce it on behalf of an individual regardless of the offensiveness of the practice of one nation to the other"); United States v. Rauscher, 119 U.S. 407, 419 (1886) (holding that if a treaty is self-executing, "courts are bound to take judicial notice [of], and to enforce in any appropriate proceeding the rights of persons growing out of th[e] treaty"); United States v. Wiggins, 39 U.S. (14 Pet.) 334, 349 (1840) (holding that because titles to land "stood confirmed" by a treaty between the United States and Spain, the individual rights "must be so recognised ... in our Courts" (internal quotation marks omitted)).

144213 F.3d 82, $94(2000)$.

145 Id. at 94. 
sponded with a wonderfully concise summary of the import of Ware $v$. Hylton, Schooner Peggy, Foster, and their progeny:

[T]his contention fundamentally miscomprehends the status of treaties in our constitutional scheme. The Supremacy Clause declares the Constitution, federal law, and treaties to be "the supreme Law of the Land." It is well-established that under the Supremacy Clause a self-executing treaty-one that operates of itself without the aid of legislation-is to be regarded in the courts as equivalent to an act of the legislature .... .

Thus, contrary to the position of . . . the petitioner, the Constitution not only allows, but in fact requires, the courts to treat the [treaty] as equal to the federal extradition statute . . . ${ }^{146}$

But perhaps no other fact is as compelling for the force of treaties as federal law as the simple recognition that our modern legal system is subject to the influence of many hundreds of self-executing treaties. As the next section will demonstrate, building on more than two hundred years of precedent that the President and the Senate established, Congress as a whole recognized, and the Supreme Court confirmed, such treaties now extend across nearly the full substantive breadth of domestic law. Moreover, like other forms of federal law, treaties may function in a variety of ways to create, limit, or otherwise regulate rights in the U.S. domestic legal system.

C. The Pervasive Role of Treaties in Our Modern Legal Landscape

\section{Self-Executing Treaties: Attributes and Functions}

Under the traditional formulation, a self-executing treaty is one that "operates of itself without the aid of any legislative provision." 147 The full force of self-executing treaties in our domestic legal system, however, is broader and more significant than this familiar phrase might suggest.

The most prominent form of self-executing treaty is one creating an affirmative federal cause of action that individuals may assert in

$146 I d$. at 95-96 (citations omitted).

147 Foster, 27 U.S. (2 Pet.) at 314. 
court. $^{148}$ In a similar vein, a treaty (or portion of a treaty ${ }^{149}$ ) may create rights of a defensive nature, by protecting individuals from specifically defined governmental or private actions. ${ }^{150}$ A common goal of self-executing treaties, for example, is to protect property and property-related rights of foreign citizens in the United States. ${ }^{151}$ But a treaty may also create rights enforceable against individuals ${ }^{152}$ or in favor of governmental institutions. ${ }^{153}$ Even foreign governments may be the beneficiaries of self-executing treaty rights. ${ }^{154}$

148 See Restatement of Foreign Relations, supra note $75, \S 111 \mathrm{cmt}$. e (stating that where a treaty creates a private right of action, this right falls within the "arising under" jurisdiction of federal courts under Article III of the Constitution); Váqquez, Four Doctrines, supra note 92, at 719-22 (discussing the manner in which self-executing treaties may create a private right of action). For a prominent example, see Asante Techs., Inc. v. PMC-Sierra, Inc., 164 F. Supp. 2d 1142, 1147-52 (N.D. Cal. 2001), which holds that the United Nations Convention on Contracts for the International Sale of Goods creates a private right of action in federal courts and preempts state law causes of action within its scope.

149 See Lidas, Inc. v. United States, 238 F.3d 1076, 1080 (9th Cir. 2001) (holding that "it is far from uncommon for a treaty to contain both self-executing and non-self-executing provisions"); United States v. Postal, 589 F.2d 862, 884 n.35 (5th Cir. 1979) ("A treaty need not be wholly self-executing or wholly executory."); Restatement of Foreign ReLATIONS, supra note $75, \$ 111 \mathrm{cmt}$. h ("Some provisions of an international agreement may be selfexecuting and others non-self-executing.").

150 See Vázquez, Four Doctrines, supra note 92 , at 720 (discussing the notion that selfexecuting treaties may create rights of a defensive nature); see also Thomas Michael McDonnell, Defensively Invoking Treaties in American Courts-Jurisdictional Challenges Under the U.N. Drug Trafficking Convention by Foreign Defendants Kidnapped Abroad by U.S. Agents, 37 WM. \& MARY L. Rev. 1401, 1448-63 (1996) (same).

151 The protection of foreign citizens set the stage for some of the most influential early Supreme Court cases on the force of self-executing treaties. See, e.g., Chirac v. Chirac's Lessee, 15 U.S. (2 Wheat.) 259, 270-71 (1817) (discussing the legal effect of a 1778 treaty between France and the United States that "enabled the subjects of France to hold lands in the United States"); Fairfax's Devisee v. Hunter's Lessee, 11 U.S. (7 Cranch) 603,627 (1812) (upholding the rights of British subjects protected by the 1794 Treaty of Peace with Britain); Ware v. Hylton, 3 U.S. (3 Dall.) 199, 238-45 (1796) (analyzing the rights of British subjects protected by the 1783 Treaty of Peace with Great Britain). It subsequently has become quite common for the United States to conclude treaties of "friendship, commerce, and navigation," where the express purpose is to secure reciprocal individual rights within the territory of the treaty partners. For more on these treaties, see infra notes 184-86 and accompanying text.

152 Most private law treaties, for example, create both rights and obligations for individuals whose transactions fall within their scope. See, e.g., infra notes 172-80 and accompanying text (describing the examples of private law treaties in the field of commercial law).

153 See Lidas, 238 F.3d at 1080-81 (holding that because the information exchange provisions of the U.S.-France Income Tax treaty were self-executing, the treaty alone created the legal authority for the IRS to issue a summons to individual taxpayers); In re Request from Can. Pursuant to Treaty Between the U.S. and Can. on Mut. Legal Assistance in Criminal Matters, 155 F. Supp. 2d 515, 517 (M.D.N.C. 2001) (holding that because the Treaty on Mutual Legal Assistance in Criminal Matters was self-executing, the government could enforce the treaty against individuals).

154 See, e.g., 767 Third Ave. Assocs. v. Permanent Mission of Republic of Zaire to the UN, 988 F.2d 295, 300-02 (2d Cir. 1993) (holding that rights under the Vienna Convention on Consular Relations in favor of foreign governments precluded the forced eviction of a country's permanent mission to the United Nations for nonpayment of rent); In re 
The multiplicity of attributes that make a treaty self-executing bas led to substantial definitional problems. Some courts, for instance, have erroneously defined self-executing treaties to include only those that create affirmative private rights of action. ${ }^{155}$ Other courts, however, have been more careful. ${ }^{156}$ When distilled to its essence, the true touchstone of a self-executing treaty for purposes of its domestic law effect is institutional: That rights secured by the treaty are cognizable-whether by way of governmental power or private right of action or defense-in domestic courts. ${ }^{157}$ Consistent with this observation, a variety of statutes and judicially recognized principles currently comprise a formal legal framework for the exercise or protection of treaty rights in federal courts. For instance, the general federal jurisdictional statute, 28 U.S.C. $\S 1331$, provides that district court jurisdiction extends to all cases "arising under the Constitution, laws, or treaties of the United States." 158 The federal habeas corpus statute likewise authorizes district courts to entertain petitions when the petitioner is "in

Request from Can., 155 F. Supp. 2d at 517-20 (holding that because the Treaty on Mutual Legal Assistance in Criminal Matters was self-executing, the IRS could enforce, via subpoena, Canada's right to request certain information about individuals in the United States).

155 See, e.g., Hamdi v. Rumsfeld, 316 F.3d 450, 468 (4th Cir. 2003) ("Courts will only find a treaty to be self-executing if the document, as a whole, evidences an intent to provide a private right of action.' " (quoting Goldstar (Panama) S.A. v. United States, 967 F.2d 965, 968 (4th Cir. I992))).

156 See, e.g., Int'l Café, S.A.L. v. Hard Rock Café Int'I (U.S.A.), Inc., 252 F.3d 1274, 1277 n.5 (11th Cir. 2001) (per curiam) (observing that a treaty is self-executing if it "directly accords enforceable rights to persons without the benefit of Congressional implementation'" (quoting Haitian Refugee Ctr., Inc. v. Baker, 949 F.2d 1109, 1110 (11th Cir. 1991))); see also Restatement of Foreign Relations, supra note $75, \$ 111 \mathrm{cmt}$. h ("Whether a treaty is self-executing is a question distinct from whether the treaty creates private rights or remedies.").

157 It is also possible that a treaty may create rights enforceable in administrative bodies, i.e., through administrative hearings. See Restatement of Foreign Relations, supra note $75, \S 325 \mathrm{cmt}$. d (observing that treaties may "lay down rules to be enforced by the parties through their internal courts or administrative agencies").

15828 U.S.C. $\$ 1331$ (2000). For similar statutory recognition of the direct force of self-executing treaties as federal law, see $i d$. $\$ 1362$, providing that district courts shall have original jurisdiction of all civil actions brought by recognized Indian tribes "wherein the matter in controversy arises under . . treaties of the United States", and id. $\$ 1505$, providing that tbe United States Court of Federal Claims shall have jurisdiction of any claim against the United States in favor of recognized Indian tribes "whenever such claim is one arising under . . treaties of the United States.” Cf. 33 U.S.C. $§ 1518$ (a) (1) (2000) (providing that "treaties of the United States shall apply to a deepwater port licensed under this chapter and to activities connected, associated, or potentially interfering with the use or operation of any such port" and that "[n]othing in this chapter shall be construed to relieve, exempt, or immunize any person from any other requirement imposed by . . . treaty"); 42 U.S.C. $\$ 9163$ (a) (1) (2000) (providing that "treaties of the United States shall apply to an ocean thermal energy conversion facility or plantship" meeting certain criteria). 
custody in violation of . . treaties of the United States."159 Compelling authority also supports the proposition that violations of self-executing treaty rights can create the foundation for a private right of action for damages under $\S 1983 .{ }^{160}$ The particular way in which a self-executing treaty secures individual rights may even trigger a waiver of federal sovereign immunity. ${ }^{161}$

With the preemptive force of federal law, a self-executing treaty also displaces any inconsistent rights or obligations created under state law, be they constitutional, statutory, administrative, or otherwise. ${ }^{162}$ Even an implied provision of a treaty may be self-executing, ${ }^{163}$ and thus have this preemptive effect. ${ }^{164}$ Because they enjoy the same constitutional dignity as statutes, treaties will even displace earlier inconsistent federal statutes, ${ }^{165}$ although the reverse is also true under the "later-in-time rule." 166 Nonetheless, the particular force of the in-

15928 U.S.C. $\$ 2254$ (a); see also id. $\$ 2241$ (c) (3) (same with respect to petitioners in prison). The reference to treaties in the habeas statute has a long lineage. As early as 1867 , the congressional statute authorizing habeas relief provided that federal district courts "shall have power to grant writs of habeas corpus in all cases where any person may be restrained of his or her liberty in violation of the constitution, or of any treaty or law of the United States ...." Act of Feb. 5, 1867, ch. 28, § 1, 14 Stat. 385, 385 (current version at 28 U.S.C. $\$ 2254(\mathrm{a})$ ). For early applications of the principle, see Wildenhus's Case, 120 U.S. 1, 17 (1887), and United States v. Rauscher, 119 U.S. 407, 430-31 (1886).

160 See 42 U.S.C. $\$ 1983$ (creating a private right of action for violations of rights secured by the Constitution and federal laws); Standt v. City of New York, 153 F. Supp. 2d 417, 422-30 (S.D.N.Y. 2001) (holding that the plain language of Article 36 of the Vienna Convention on Consular Relations, coupled with its implementing regulations, demonstrate that the Article creates a private right enforceable in a $\$ 1983$ action for damages)

161 See Telesat De Pan., S.A. v. U.S. Dep't of Defense, 1992 WL. 188153, at ${ }^{* * 6}$ (Fed. Cir. Aug. 7, 1992) (holding that if a treaty creates a private cause of action against the federal government, it may form the basis for a waiver of sovereigu immunity).

162 See U.S. ConST. art. VI, cl. 2 (providing that treaties are the supreme law of the land, which even state law judges must apply, "any Thing in the Constitution or Laws of any State to the Contrary notwithstanding."); Wildenhus's Case, 120 U.S. at 17 ("[A] treaty is part of the supreme law of the United States, and has the same force and effect in New Jersey that it is entitled to elsewhere.").

163 See Rauscher, 119 U.S. at 422-23 (holding that an extradition treaty included an implied provision prohibiting extradition on any bases other than those explicitly enumerated). But cf. United States v. Alvarez-Machain, 504 U.S. 655, 667-69 (1992) (accepting that "[i]n Rauscher, we implied a term in [that extradition treaty] because of the practice of nations with regard to extradition treaties," but holding that the extradition treaty at issue did not merit such an interpretation).

164 The power of federal courts to fill gaps in self-executing treaties is of course central to the issue of the federal common law powers of courts for the law within the scope of treaties. This issue is analyzed in much greater detail below. See infra Parts IV.B-C.

165 See id.; see also Whitney v. Robertson, 124 U.S. 190, 194 (1888) ("By the Constitution, a treaty is placed on the same footing, and made of like obligation, with an act of legislation .... [B] ut if the two are inconsistent: the one last in date will control the other, provided always the stipulation of the treaty . . . is self-executing.").

166 See Reid v. Covert, 354 U.S. 1, 18 (1957) (plurality opinion) (stating that "when a statute which is subsequent in time is inconsistent with a treaty, the statute to the extent of the conflict renders the treaty null"); Chae Chan Ping v. United States (The Chinese Ex- 
ternational obligation that attends a treaty ${ }^{167}$ requires that courts apply a strong presumption against congressional intent to violate a treaty. ${ }^{168}$ Further, federal courts have specifically declared that mere procedural legislation designed to ease the application of a self-executing treaty should not be interpreted to limit or otherwise modify substantive treaty rights. ${ }^{169}$

\section{The Broad Substantive Influence of Self-Executing Treaties}

In recent years the subject of treaties has incited substantial, sometimes heated, scholarly debate. Still, surprisingly little is known about the cumulative impact of treatises on our domestic legal system. The absence of any comprehensive system-including within the structure of the Unites States Code-through which the government may collect and organize self-executing treaties by subject matter may, in large part, explain this significant gap in knowledge. Moreover, the analysis necessary to determine whether a particular treaty creates domestically enforceable rights is notoriously difficult. ${ }^{170}$ To provide the necessary backdrop for the subsequent analysis of federal common law, this section examines the depth and breadth of the influence of self-executing treaties in the modern U.S. legal system.

Perhaps the most striking observation that emerges from a comprehensive examination is the sheer number of existing self-executing treaties. The number of treaties that contain self-executing provisions is now over four hundred (even excluding treaties with Native American tribes ${ }^{171}$ ). Moreover, many of these treaties are multilateral and

clusion Case), 130 U.S. 581, 601-02 (1889) (holding that a treaty must yield to a later statute excluding aliens).

167 This Article examines the implications of the international obligation aspect of a treaty in substantially greater detail below. See infra notes 490-502 and accompanying text.

168 See Trans World Airlines, Inc. v. Franklin Mint Corp., 466 U.S. 243, 252 (1984) ("There is ... a firm and obviously sound canon of construction against finding implicit repeal of a treaty in ambiguous congressional action. 'A treaty will not be deemed to have been abrogated or modified by a later statute unless such purpose on the part of Congress has been clearly expressed.' (quoting Cook v. United States, 288 U.S. I02, 120 (1933))). The Court further observed that "[l] egislative silence is not sufficient to abrogate a treaty." Id. (citing Weinberger v. Rossi, 456 U.S. 25, 32 (1982)).

169 See In re Comm'r's Subpoenas, 325 F.3d 1287, I297 (11th Cir. 2003) (holding that procedural legislation that makes a treaty more convenient cannot amend or abrogate the treaty); Cannon v. U.S. Dep't of Justice, 973 F.2d 1190, 1197 (5th Cir. 1992) ("Procedural legislation which makes operation of a Treaty more convenient cannot amend or abrogate a self-executing Treaty.").

170 Courts have aptly described the issue of whether a treaty is self-executing as among the "most confounding" distinctions in the law of treaties. See, e.g., United States v. Postal, 589 F.2d 862, 876 (5th Cir. 1979); United States v. Noriega, 808 F. Supp. 791 , 797 (S.D. Fla. 1992); see also Vázquez, Four Doctrines, supra note 92, at 695 (noting that the distinction has caused "much confusion").

171 A substantial part of the law governing the rights of Native Americans and Native American tribes is governed by what are in effect self-executing treaties. Before it ceased the practice in the late 1800 s, the United States concluded nearly four hundred treaties 
thus may apply to dozens of countries. ${ }^{172}$ Equally remarkable is their substantive law coverage. Self-executing treaties now address such diverse fields as commercial law, criminal law, property law, tax law, civil procedure, administrative law, and family law.

The field of commercial law represents one of the most prominent examples of the influence of self-executing treaties. The United States has already ratified more than half a dozen such treaties, some of which are the most detailed and extensive self-executing treaties in existence. Extensive and detailed treaties include the United Nations Convention on Contracts for the International Sale of Goods ${ }^{173}$ (in force for more than sixty countries ${ }^{174}$ ), which comprehensively displaces the state-level Uniform Commercial Code for international sales transactions; ${ }^{175}$ a companion treaty on the limitation period for international sale of goods transactions; ${ }^{176}$ and the carriage of goods provisions of the Warsaw Convention on International Air Transportation. ${ }^{177}$ Beyond these already ratified treaties, ${ }^{178}$ the potential for fu-

with Native American tribes. See generally 2 Indian Affairs: Laws and Treaties (Charles J. Kappler ed., 1904) (setting forth 389 such treaties concluded prior to 1883, when the United States ceased recognizing the formal sovereignty of such entities). Federal courts have repeatedly held that such treaties operate as federal law, establishing rights and directly protecting the interests of both tribes and individuals. See, e.g., Tsosie v. United States, 11 Cl. Ct. 62, 73 (1986) (agreeing that treaties with Native American tribes "are virtually always self-executing in nature" and observing that courts have consistently so found).

172 See, e.g., 8 C.F.R. $\$ 236.1$ (e) (2003) (listing over fifty countries affected by treaties aimed to protect foreign citizens); see also infra note 186 and accompanying text.

173 United Nations Convention on Contracts for the International Sale of Goods, opened for signature Apr. 11, 1980, S. TREATY DOC. No. 98-9, 1489 U.N.T.S. 58 [hereinafter CISG]. The English language text of the treaty is also available at U.S. Ratification of 1980 United Nations Convention on Contracts for the International Sale of Goods: Official English Text, 52 Fed. Reg. 6262, 6263-80 (Mar. 2, 1987).

174 For a complete list of the member states of the CISG, see United Nations Commission on International Trade Law (UNCITRAL), Status of Conventions and Model Laws, at http://www.uncitral.org/english/status/status-e.htm (last modified Jan. 23, 2004).

175 See Asante Techs., lnc. v. PMC-Sierra, Inc., 164 F. Supp. 2d 1142, 1147-52 (N.D. Cal. 2001) (holding that the CISG creates a private cause of action in federal courts and preempts state law causes of action within its scope).

176 See United Nations Convention on the Limitation Period in the International Sale of Goods, With Protocol, opened for signature June 14, 1974, S. TREATY Doc. No. 103-10, 1511 U.N.T.S. 3.

177 See Convention for the Unification of Certain Rules Relating to International Transportation by Air, Oct. 12, 1929, 49 Stat. 3000, 137 L.N.T.S. 11, reprinted in 49 U.S.C. $\$ 40105$ note (2000). Among numerous other self-executing provisions, the Warsaw Convention regulates certain aspects of the international air transportation of commercial cargo. See Trans World Airlines, Inc. v. Franklin Mint Corp., 466 U.S. 243, 254-60 (1984) (analyzing the Convention with regard to goods lost in air transportation). For examples of the Supreme Court applying the Warsaw Convention to other private law issues, see $E l A l$ Israel Airlines, Ltd. v. Tsui Yuan Tseng, 525 U.S. 155, 166-76 (1999) (interpreting and applying the Warsaw Convention in a personal injury suit), and Zicherman v. Korean Air Lines Co., 516 U.S. 217, 221-31 (1996) (same).

178 For other examples of self-executing commercial law treaties that the United States has ratified, see International Convention for Safe Containers, opened for signature Dec. 2, 
ture expansion in the field of commercial law is substantial. The United States has participated in the completion of a variety of similar treaties on subjects as diverse as financial leasing, factoring, bills of exchange and promissory notes, secured transactions, and receivables financing. ${ }^{179}$ Collectively, these treaties form a "proto-'International Uniform Commercial Code." "180

Self-executing treaties also play a prominent role in the field of tax law. Nearly sixty tax treaties currently in force contain, either by express statement or by their nature, self-executing provisions. ${ }^{181}$

1972, 29 U.S.T. 3707, 988 U.N.T.S. 43; Customs Convention on Containers, May 18, 1956, 20 U.S.T. 301, 338 U.N.T.S. 103; and Convention on the International Recognition of Rights in Aircraft, June 19, 1948, 4 U.S.T. 1830, 310 U.N.T.S. 151 [hereinafter CIRRA]. See also Container Corp. of Am. v. Franchise Tax Bd., 463 U.S. 159, 185-86 (1983) (discussing U.S. tax obligations under the container conventions); Japan Line, Ltd. v. County of Los Angeles, 441 U.S. 434, 446 (1979) (analyzing the 1956 Convention on Containers as federal law and holding that "[w]hen construing Congress' $[\mathrm{s}]$ power to 'regulate Commerce with foreign Nations,' a more extensive constitutional inquiry is required" than wben construing its Commerce Clause power (quoting U.S. ConST. art. I, § 8, cl. 3)); Triad Int'l Maint. Corp. v. Guernsey Air Leasing, Ltd., 178 F. Supp. 2d 547, 552-53 (M.D.N.C. 2001) (recoguizing that CIRRA created enforceable individual rights).

179 See, e.g., United Nations Convention on the Assignment of Receivables in International Trade, Dec. 12, 2001, 41 I.L.M. 776; UNIDROIT Convention on International Interests in Mobile Equipment, Nov. 16, 2001, available at http://www.uncitral.org/english/ travaux/payments/receivables/travaux_receivables_index_e.htm; United Nations Convention on Independent Guarantees and Stand-by Letters of Credit, Dec. 11, 1995, 35 I.L.M 735; United Nations Convention on International Bills of Exchange and International Promissory Notes, Dec. 9, 1988, 28 I.L.M. 170; UNIDROIT Convention on International Factoring, May 28, 1988, 27 I.L.M. 943; UNIDROIT Convention on International Financial Leasing, May 28, 1988, 27 I.L.M. 931; see also Convention on Agency in the International Sale of Goods, Feb. 17, 1983, 22 I.L.M. 249 (agreeing to basic principles regarding agency creation and authority in international sales).

180 Van Alstine, supra note 25, at 699.

181 According to the Internal Revenue Service, the United States has tax treaties with fifty-four countries. See Internal Revenue Service, Income Tax Treaties, at http:// www.irs.gov/businesses/corporations/article/0,id $=96739,00 . \mathrm{html}$ (last visited Jan. 27, 2004). Indeed, the "technical explanations" appended to thirty of these treaties contain an express statement of self-execution. See, e.g., Dep't of Treasury, Technical Explanation of the Convention Between the United States of America and the Republic of South Africa for the Avoidance of Double Taxation and the Prevention of Fiscal Evasion with Respect to Taxes on Income and Capital Gains, art. 22 (Jan. 1, 1998), available at http://www.irs.gov/pub/irs-trty/safrtecb.pdf (observing that certain provisions of the treaty "will be self-executing"); Dep't of Treasury, Technical Explanation of the Convention and Protocol Between the United States of America and the Federal Republic of Germany for the Avoidance of Double Taxation and the Prevention of Fiscal Evasion with Respect to Taxes on Income and Capital and to Certain Other Taxes Signed at Bonn on August 29, 1989, art. 28 (Jan. 1, 1990), available at http://www.irs.gov/pub/irs-trty/ germtech.pdf (noting that certain treaty provisions "will be self-executing"); Dep't of Treasury, Technical Explanation of the Convention Between the Government of the United States of America and the Government of the French Republic for the Avoidance of Double Taxation and the Prevention of Fiscal Evasion with Respect to Taxes on Income and Capital Signed at Paris on August 31, 1994, available at http://www.irs.gov/pub/irs-trty/francetech.pdf (stating that certain treaty provisions "are intended to be self-executing"); see also, e.g., Lidas, Inc., v. United States, 238 F.3d 1076, 1080 (9th Cir. 2001) (stating that the U.S.-France double taxation treaty was self-executing); Columbia Marine Servs., Inc. v. Reffet Ltd., 861 F.2d 18, 21-22 (2d Cir. 1988) (same with respect to the U.S.-U.K. double taxation treaty); Estate of Silver 
Among other things, these treaties create individual rights against governmental action ${ }^{182}$ and government rights against individuals. ${ }^{183}$

The most distinguished tradition of self-executing treaties is found in the protection of foreign citizens' rights in the United States. From the first years of the new Constitution-indeed, even beforethe United States began concluding treaties of "amity, commerce and navigation." 184 The very purpose of these treaties was to secure reciprocal property and procedural rights for foreign citizens. ${ }^{185}$ These self-executing treaties now protect the rights of citizens of some sixty countries $^{186}$ with regard to their personal and commercial interests in the United States.

Even the international aspects of civil procedure and family law are now subject to self-executing treaties. For example, the United States has already ratified two prominent civil procedure treaties designed to facilitate, respectively, international service of process ${ }^{187}$ and

v. Comm'r, 120 T.C. 430, 433-34 (2003) (explaining that the U.S.-Canada tax treaty is selfexecuting and overrides U.S. statutes).

182 See Robert Thornton Smith, Tax Treaty Interpretation by the Judiciary, 49 TAx LAW. $845,848-50$ (1996) (observing that "[i]ncome tax treaties generally are viewed as self-executing, requiring no further legislation to implement their provisions" and noting the variety of ways in which such treaties have been found to protect individual taxpayer rights). 183 See Lidas, 238 F.3d at 1079-81 (holding that the information exchange provisions in the U.S.France double taxation treaty are self-executing and thus formed a valid basis for the IRS to issue a summons against an individual taxpayer).

184 Examples include the Treaty of Friendship, Limits and Navigation, Between the United States of America, and the King of Spain, Oct. 27, 1795, U.S.Spain, 8 Stat. 138; and the Treaty of Amity, Commerce and Navigation, Between His Britannic Majesty and the United States of America, by Their President, with the Advice and Consent of Their Senate, Nov. 19, 1794, Gr. Brit.-U.S., 8 Stat. 116.

185 See, e.g., Blanco v. United States, 775 F.2d 53, 60 (2d Cir. 1985) (holding that a treaty of friendship, commerce, and consular rights with Honduras was self-executing and observing generally that "[ $t$ ]he provisions of [such] treaties are self-executing"); Spiess v. C. Itoh \& Co. (America), Inc., 643 F.2d 353, 356 (5th Cir. 1981) (holding with regard to a treaty of friendship, commerce, and navigation with Japan that such "treaties, including the Japanese Treaty, are self-executing treaties, that is, they are binding domestic law of their own accord, without the need for implementing legislation").

186 See 8 C.F.R. $\$ 236.1$ (e) (2003) (listing such treaties). Another, more controversial, treaty in this vein is the Vienna Convention on Consular Relations, Apr. 24, 1963, art. 36, 21 U.S.T. 77, 100-01, 596 U.N.T.S. 261, 292-94 [hereinafter VCCR]. Whether this treaty is self-executing at all has been the subject of substantial debate. See, e.g., United States v. Emuegbunam, 268 F.3d 377, 391-94 (6th Cir. 2001) (holding that Article 36 of the VCCR does not confer individual rights and therefore is not self-executing), cert. denied, 535 U.S. 977 (2002); United States v. Jimenez-Nava, 243 F.3d 192, 197-98 (5th Cir. 2001) (same); Standt v. City of New York, 153 F. Supp. 2d 417, 427 (S.D.N.Y. 2001) ("[T]he language of the VCCR, coupled with its 'legislative history' and subsequent operation, suggest that Article 36 of the Vienna Convention was intended to provide a private right of action to individuals detained by foreign officials."); United States v. Torres-Del Muro, 58 F. Supp. 2d 931, 933 (C.D. Ill. 1999) (holding same).

187 See Convention on the Service Abroad of Judicial and Extrajudicial Documents in Civil or Commercial Matters, opened for signature Nov. 15, 1965, 20 U.S.T. 361, 658 U.N.T.S. 163; see also Volkswagenwerk Aktiengesellschaft v. Schlunk, 486 U.S. 694, 698-99 (1988) 
the taking of evidence abroad. ${ }^{188}$ In the field of family law as well, the United States has ratified a treaty that creates directly enforceable rights for custodial parents and guardians in the case of international child abductions. ${ }^{189}$

The most common subject of self-executing treaties is the international aspects of criminal law. For example, the United States now has in force extradition treaties with nearly 110 countries. ${ }^{190}$ Federal courts have repeatedly recognized that this category of treaties creates rights that are directly enforceable by individuals who are subject to extradition proceedings. ${ }^{191}$ In a similar vein, the United States has concluded over a dozen prisoner exchange treaties covering nearly seventy countries. ${ }^{192}$ Such treaties create both the legal infrastructure

(holding that the "Convention pre-empts inconsistent methods of service prescribed by state law in all cases to which it applies").

188 See Convention on the Taking of Evidence Abroad in Civil or Commercial Matters, Mar. 18, 1970, 23 U.S.T. 2555, 847 U.N.T.S. 231, reprinted in 28 U.S.C. $\$ 1781$ (2000); see also Société Nationale Industrielle Aérospatiale v. U.S. Dist. Court, 482 U.S. 522, 533-40 (1987) (concluding that "the Hague Convention [is] the law of the United States," but that it does not preclude resort to discovery under domestic law).

189 See Convention on the Civil Aspects of International Child Abduction, Oct. 25, 1980, T.I.A.S. No. 11,670, 1343 U.N.T.S. 97, reprinted in Fed. Reg. 10,493 [hereinafter Convention on International Child Abduction]; see also 42 U.S.C. \$11601(a) (4) (2003) (setting forth a congressional finding that the International Child Abduction convention "establishes legal rights ... for the prompt return of children who have been wrongfully removed or retained, as well as for securing the exercise of visitation rights"); id. $\$ 11601$ (b) (2) (setting forth a congressional declaration that the provisions of the legislation "are in addition to and not in lieu of the provisions of the Convention"). In 1998, the Senate also gave its advice and consent to the Convention on Protection of Children and Cooperation in Respect of Intercountry Adoption, May 29, 1993, S. Treaty Doc. No. 10551 , at III (1998).

190 See 18 U.S.C. $\$ 3181$ note (2000) (listing existing extradition treaties).

191 See, e.g., Cheung v. United States, 213 F.3d 82, 95 (2d Cir. 2000) (stating that the Hong Kong extradition "[a]greement is self-executing" and that "the Constitution not only allows, but in fact requires, the courts to treat the Agreement as equal to the federal extradition statute"); United States v. Puentes, 50 F.3d 1567, 1575 (11th Cir. 1995) (holding that the extradition treaty between the United States and Uruguay could be enforced directly by the person extradited, subject to the "sufferance of the requested nation"); see also United States v. Alvarez-Machain, 504 U.S. 655, 667 (1992) (interpreting an extradition treaty with Mexico as carrying the force of law and enforceable on an individual's behalf); Terlinden v. Ames, 184 U.S. 270, 288 (1902) ("Treaties of extradition are executory in their character ...."). The United States is also a party to the multilateral Extradition Convention Between the United States of America and Other American Republics, Dec. 26, 1933, 49 Stat. 3111, Pan Am. T.S. No. 37.

192 These agreements are variously referred to as treaties on the execution of penal sentences or conventions on the transfer of sentenced persons. The list of such treaties includes the following: Convention on the Transfer of Sentenced Persons, Jan. 25, 1983, U.S.Fr., 35 U.S.T. 2847; Treaty on Cooperation in the Execution of Penal Sentences, U.S.Thail., Oct. 29, 1982, S. TREATY Doc. No. 98-8 (1983); Treaty on the Execution of Penal Sentences, July 6, 1979, U.S.-Peru, 32 U.S.T. 1471; Treaty on the Enforcement of Penal Judgments, June 7, 1979, U.S.-Turk., 32 U.S.T. 3187; Treaty on the Execution of Penal Sentences, Jan. 11, 1979, U.S.-Pan., 32 U.S.T. 1565; Treaty on the Execution of Penal Sentences, Feb. 10, 1978, U.S.-Bol., 30 U.S.T. 796; Treaty on the Execution of Penal Sentences, Mar. 2, 1977, U.S.Can., 30 U.S.T. 6263; Treaty on the Execution of Penal 
for the transfer of prisoners to their respective home countries and certain enforceable rights for transferees. ${ }^{193}$ The United States also increasingly relies on self-executing treaties to facilitate the investigation and prosecution of international criminal activity. Over fifty of these "mutual legal assistance treaties" and related agreements are now in force for the United States. ${ }^{194}$ The purpose of these treaties is to create reciprocal rights of government agencies to issue subpoenas and employ similar investigative vehicles with regard to international crimes. ${ }^{195}$

Self-executing treaties thus currently exert a broad and expanding influence on our domestic legal system. Nonetheless, the existence of a self-executing treaty does not mean that the treatylawmakers have provided every answer to every question within its scope. That is, just like other forms of law, the treaty-lawmakers often will be unable to achieve precise consensus on all issues or otherwise to articulate precisely how the courts are to resolve all related disputes. And the rapid pace of social and technological advancement means that the treaty drafters will be unable to foresee some issues entirely. The result is that treaties routinely will have ambiguities or unintended gaps in their regulatory scheme. The risk of this indeter-

Sentences, Nov. 25, 1976, U.S.-Mex., 28 U.S.T. 7399. State Department records also show that similar treaties are in force with Hong Kong, the Marshall lslands, Micronesia, and Palau. See U.S. Dep't of State, Prisoner Transfer Treaties, at http://travel.state.gov/transfer.html (last visited Jan. 27, 2004). In addition, the United States is a party to two multilateral prisoner transfer treaties. See Inter-American Convention on Serving Criminal Sentences Abroad, June 9, 1993, S. TREATY Doc. No. 104-35 (1996) (entered into force for the United States June 24, 2001 and in effect for nine countries); Convention on the Transfer of Sentenced Persons, Mar. 21, 1983, 35 U.S.T. 2867, 1496 U.N.T.S. 91 (in effect for over fifty countries).

193 See Cannon v. U.S. Dep't of Justice, 973 F.2d 1190, 1192 (5th Cir. 1992) (holding that the U.S.-Mexico treaty on the execution of penal sentences was self-executing and thus imposed directly enforceable limitations on the U.S. parole commission's discretion in granting parole to a prisoner transferred from Mexico).

194 See, e.g., Treaty on Mutual Legal Assistance in Criminal Matters, Nov. 23, 1993, U.S.S. Korea, S. TREATY Doc. No. 104-1 (1995); Treaty on Mutual Legal Assistance in Criminal Matters, Dec. 4, 1990, U.S.-Arg., S. TreATY Doc. No. 102-18 (1991); Mutual Legal Assistance Cooperation Treaty with Mexico, Dec. 9, 1987, U.S.-Mex., S. TREATY Doc. No. 100-13 (1988); Treaty with Canada on Mutual Legal Assistance in Criminal Matters, Mar. 18, 1985, U.S.-Can., S. TREATY Doc. No. 100-14 (1988); see also U.S. Dep't of State, Mutual Legal Assistance in Criminal Matters Treaties (MLATs) and Other Agreements, at http:// travel.state.gov/mlat.html (last visited Jan. 27, 2004) (listing and describing other treaties and agreements).

195 See In re Comm'r's Subpoenas, 325 F.3d 1287, 1290-91 (11th Cir. 2003) (describing the operation of mutual legal assistance treaties (MLATs) and holding that the MLAT with Canada was self-executing and thus, upon its entry into force, it "became a law of this land on par with a federal statute"); United Kingdom v. United States, 238 F.3d 1312, 1317 (11th Cir. 2001) (characterizing the MLAT with the United Kingdom as self-executing); In $r e$ Erato, 2 F.3d 11, 15 (2d Cir. 1993) (same regarding the MLAT with the Netherlands). 
minacy in legal standards in fact may be even greater with international treaties. ${ }^{196}$

Unfortunately, judicial doctrine and scholarly analysis have not kept pace with these developments in the field of treaty law. In the purely domestic law arena, extensive authority provides guidance on the proper scope of federal common law, particularly the role of separation of powers and federalism concerns in judicial application of federal statutes. ${ }^{197}$ But there is no intense scholarly analysis or judicial guidance on the proper force of these core constitutional values in federal court with respect to treaty law as the "supreme Law of the Land." 198

To set the context for the analysis that follows, Part II examines the limits imposed on judicial lawmaking through the general prohibition on federal common law, as influenced by the non-delegation doctrine. Parts III and IV then analyze the force of these boundaries on the law within the scope of self-executing treaties. We will see that a self-executing treaty ultimately reflects a determination by properly empowered federal institutions that a particular matter should be removed from state lawmaking and replaced by federal rules of decision, including, as appropriate, rules constructed by federal courts.

\section{II}

The Constitutional Limits on Federal JUdicial LAWMAKING

\section{A. Boundaries of Federal Common Law}

It is now nearly a constitutional article of faith, in particular for the modern Supreme Court, ${ }^{199}$ that "federal courts, unlike their state counterparts, are courts of limited jurisdiction that have not been vested with open-ended lawmaking powers." 200 This proposition traces its lineage to one of the most famous (and vexatious) opinions of the 20th century, Erie Railroad Co. v. Tompkins. ${ }^{201}$ The Supreme

\footnotetext{
196 See Van Alstine, supra note 25, at 702-03 (describing how cultural and language differences increase the likelihood of interpretive difficulties regarding transnational legal standards).

197 See infra notes 226-64 and accompanying text (discussing the debates over federal common law under statutes).

198 U.S. Const. art. VI, cl. 2.

199 See, e.g., Atherton v. Fed. Deposit Ins. Corp., 519 U.S. 213, 218 (1997) (“'Whether latent federal power should be exercised to displace state law is primarily a decision for Congress,' not the federal courts." (quoting Wallis v. Pan Am. Petroleum Corp., 384 U.S. 63, 68 (1966))); O’Melveny \& Myers v. Fed. Deposit 1ns. Corp., 512 U.S. 79,87 (1994) (observing that the "cases in which judicial creation of a special federal rule would be justified" are "few and restricted" (quoting Wheeldin v. Wheeler, 373 U.S. 647, 651 (1963))).

200 Northwest Airlines, lnc. v. Transp. Workers Union, 451 U.S. 77, 95 (1981).

201304 U.S. 64 (1938).
} 
Court in Erie reasoned that the constitutional premise of a federal government of specific, enumerated powers prohibits federal courts from exercising general lawmaking authority, ${ }^{202}$ and nothing in Congress's mere grant of diversity jurisdiction modifies this postulate. ${ }^{203}$ The Court held, therefore, that the long-standing contrary view of Swift $v$. Tyson ${ }^{204}$ represented " an unconstitutional assumption of powers by the [c] ourts of the United States. . .."205

Erie proceeded primarily from structural and practical federalism concerns. ${ }^{206}$ In concise summary, the Erie Court reasoned that the Constitution delegated specific lawmaking powers to specific federal institutions-notably Congress and the President-but not to politically insulated federal courts. ${ }^{207}$ Thus, although subsequent develop-

202 See id. at 78 (

Congress bas no power to declare substantive rules of common law applicable in a State whetber they be local in their nature or 'general,' be they commercial law or a part of the law of torts. And no clause in the Constitution purports to confer such a power upon the federal courts.

); see also Merrill, supra note 29, at 13 (asserting that "[a]s the general structure of the Constitution and the [T] enth [A]mendment make clear, the framers anticipated that the federal government would exercise only specifically enumerated powers"). For a much earlier recognition of the same proposition, see Wheaton v. Peters, 33 U.S. (8 Pet.) 591, 658 (1834) ("It is clear, tbere can be no common law of the United States.").

203 See Erie, 304 U.S. at 73-78 (holding that "the federal courts exercising jurisdiction in diversity of citizenship cases would apply as their rules of decision the law of the State, unwritten as well as written ... [e]xcept in matters governed by the Federal Constitution or by Acts of Congress"); see also Gasperini v. Ctr. for Humanities, Inc. 518 U.S. 415, 426 (1996) ("Federal diversity jurisdiction provides an alternative forum for the adjudication of state-created rights, but it does not carry with it generation of rules of substantive law").

20441 U.S. (16 Pet.) 1 (1842), overmuled by Erie, 304 U.S. 64.

205 Erie, 304 U.S. at 79 (quoting Black \& White Taxicab \& Transfer Co. v. Brown \& Yellow Taxicab \& Transfer Co., 276 U.S. 518, 533 (1928) (Holmes, J., dissenting)). Interestingly, the Swift doctrine did not purport to apply "federal" law in the modern sense of a body distinct from state law. As Bradford Clark has carefully explained, the courts at the time of Swift $v$. Tyson would not have viewed the common law as applied by federal courts to be different from state common law. See Clark, supra note 2, at 1276-93. Rather, the judge-made law of the time was truly "common," in that federal courts would have viewed their task as one of cooperating with state courts to identify and apply the same body of law (for example, the question at issue in Swift arose under "the general law merchant" rather than federal or state law). See id. at 1283-86. Thus, federal courts were not purporting to create federal common law in competition with, and thus in derogation of, any lawmaking autbority reserved to the states by the Constitution. See id.

206 See Erie, 304 U.S. at 80 (declaring that, in applying the rule of Swift v. Tyson, "this Court and the lower courts have invaded rigbts which in our opinion are reserved by the Constitution to the several States"); see also Boyle v. United Techs. Corp., 487 U.S. 500, 517 (1988) (Brennan, J., dissenting) (arguing that "Erie was deeply rooted in notions of federalism"); Clark, supra note 2, at 1259-60 (observing that the grounds articulated in the opinion reveal that "Erie is best understood as resting on principles of judicial federalism" but also noting that federalism and the separation of powers doctrine are "mutually reinforcing" in this regard); Merrill, supra note 29, at 13 (observing that federalism "was the key principle invoked in Erie Railroad v. Tompkins").

207 See Erie, 304 U.S. at 78 ("Except in matters governed by the Federal Constitution or by Acts of Congress, tbe law to be applied in any case is the law of the State."); id. at 79 ("Supervision over either the legislative or the judicial action of the States is in no case 
ments have substantially undermined its premise about the extent of federal lawmaking power in general, ${ }^{208}$ the Court concluded that "no clause in the Constitution purports to confer such a power upon the federal courts." 209

As several scholars have observed, this reasoning also finds support in the separation of powers doctrine, ${ }^{210}$ and in the related principle of compliance with constitutionally prescribed law-making procedures. $^{211}$ In its modern manifestation, the doctrine functions

permissible except as to matters by the Constitution specifically authorized or delegated to the United States.").

208 The Erie Court reasoned that even "Congress has no power to declare substantive rules of common law applicable in a State whether they be local in their nature or 'general,' be they commercial law or a part of the law of torts." Id. at 78. Supreme Court jurisprudence since Erie, however, has led to a greatly expanded understanding of the scope of Congress's commerce clause powers. See, e.g., Garcia v. San Antonio Metro. Transit Auth., 469 U.S. 528, 554 (1985) (concluding that states are not immune from federal Commerce Clause regulation unless the requirements are "destructive of state sovereignty or violative of any constitutional provision"); Heart of Atlanta Motel, Inc. v. United States, 379 U.S. 241, 258 (1964) (holding that Congress has the power to regulate local activities "which might have a substantial" effect on interstate commerce); United Wickard v. Filburn, 317 U.S. 111, 127-29 (1942) (concluding that Congress may regulate even individual activities if, in the aggregate, they affect interstate commerce); United States v. Darby, 312 U.S. 100, 114 (1941) (concluding that the Commerce Clause allows Congress to exclude articles from interstate commerce which "it may conceive to be injurious to the public health, morals or welfare"). In recent years, however, the Supreme Court has begun to circumscribe Congress's federal lawmaking power under the Commerce Clause. See United States v. Morrison, 529 U.S. 598, 617 (2000) (finding that Congress cannot regulate noneconomic local activity even if, in the aggregate, it has a substantial effect on interstate commerce); United States v. Lopez, 514 U.S. 549, 561-62 (1995) (concluding that congressional Commerce Clause powers do not extend to the regnlation of noneconomic activities having only a potentially attenuated effect on interstate commerce).

209 Erie, 304 U.S. at 78.

210 See Clark, supra note 2, at 1260 (observing that federalism and separation of powers form a "mutually reinforcing" basis for the propriety of federal common law); Merrill, supra note 29, at 19-24 (analyzing the role of the separation of powers doctrine for the legitimacy of federal common law); Redish, supra note 29, at 767 (arguing that with regard to federal common law not sanctioned by Congress, the "two structural political values" of federalism and separation of powers "are inextricably intertwined"). But see Field, supra note 29 , at 931 (arguing that

the[ ] federalism issues that a system of broad federal common law raises are significant and are far more serious than are any separation of powers issues. The issue of the proper scope of federal common law is not primarily a separation of powers issue, in which Congress and the courts are pitted against each other. It would reduce states' sphere of influence if federal common law were very broadly made, but it would not detract sig) . nificantly from Congress's power.

211 See Bradford R. Clark, Separation of Powers as a Safeguard of Federalism, 79 TEx. L. REv. 1321, 1403-22 (2001) (analyzing how strict adberence to lawmaking procedures through separation of powers functions "to prevent federal courts from displacing state law in the absence of federal law adopted according to constitutionally prescribed procedures"); Merrill, supra note 29, at 24-27 (analyzing an "electoral accountability principle" as a separate limit on federal common law, but observing that this principle "is important insofar as it reinforces the separation-of-powers principle"). 
principally as "a self-executing safeguard against the encroachment or aggrandizement of one branch at the expense of the other."212 With specific reference to federal common law, the Supreme Court has emphasized in Erie's progeny that "the federal lawmaking power is vested in the legislative, not the judicial, branch of government."213

Beyond these constitutional values, federal common law also faces a legislative obstacle. As early as 1789 , the Judiciary and Judicial Procedure Code of the United States expressly prescribed the substantive law that federal courts must apply in civil actions. ${ }^{214}$ ln its present form, this Rules of Decision Act provides that " $[t]$ he laws of the several states, except where the Constitution or treaties of the United States or Acts of Congress otherwise require or provide, shall be regarded as rules of decision in civil actions in the courts of the United States, in cases where they apply." ${ }^{115}$ The constitutional premise of Erie may well mean that, in cases based solely on diversity jurisdiction, this Act adds little to an understanding of the limits on federal court lawmaking. ${ }^{216}$ As this Article will demonstrate in more detail below, ${ }^{217}$ however, the words "require or provide" may carry a more potent, positive message when federal courts act within the scope of an existing federal enactment.

When read together, Erie and the Rules of Decision Act nonetheless establish the core proposition that federal courts "do not possess a general power to develop and apply their own rules of decision," 218 at least where those rules of decision do not flow from the content of a

212 Buckley v. Valeo, 424 U.S. 1, 122 (1976) (per curiam); see also Mistretta v. United States, 488 U.S. 361,382 (1989) (restating this observation with approval); INS v. Chadha, 462 U.S. 919, 951 (1983) (emphasizing this function of the separation of powers doctrine). 213 Northwest Airlines, Inc. v. Transp. Workers Union, 451 U.S. 77, 95 (1981); see also Camps Newfound/Owatonna, Inc. v. Town of Harrison, 520 U.S. 564, 615 (1997) (Thomas, J., dissenting) (noting that, as a general proposition, "since the watershed case of Erie [R.R.] Co. v. Tompkins, this Court has rejected the notion that it can create a federal common law to fill in great silences left by Congress").

214 See The Judiciary Act of 1789, ch. 20, $\$ 34,1$ Stat. 73, 92 (1789) (codified as amended at 28 U.S.C. $\$ 1652(2000)$ ). The Act states that "the laws of the several states, except where the Constitution, treaties or statutes of the United States shall otherwise require or provide, shall be regarded as rules of decision in trials at common law in the courts of the United States in cases where they apply," $i d$., a rule that is similar to the current code.

21528 U.S.C. $\$ 1652$.

216 See Erie R.R. Co. v. Tompkins, 304 U.S. 64, 72 (1938) (suggesting that because of the constitutional limits on federal court lawmaking, the Rules of Decision Act may be "'merely declarative of the rule which would exist in [its] absence" (quoting Mason v. United States, 260 U.S. 545, 559 (1923))); see also Guaranty Trust Co. v. York, 326 U.S. 99, 103-04 (1945) (observing with regard to actions in equity that the Rules of Decision Act "was deemed, consistently for over a hundred years, to be merely declaratory of what would in any event have governed the federal courts and [that it] therefore was equally applicable to equity suits").

217 See infra notes 394-96, 428-29 and accompanying text.

218 City of Milwaukee v. Illinois, 451 U.S. 304, 312 (1981). 
formal federal enactment. ${ }^{219}$ The field of questionable "federal common law"220 or (more precisely) "federal judge-made law"221 instead begins where a federal court creates a rule of decision whose content is not mandated by an authoritative norm of positive federal law. ${ }^{222}$ Beyond this point, any valid exercise of lawmaking power by the federal judiciary must have a foundation in some other, independent source of authority. ${ }^{223}$

We will see immediately below that federal courts may find such authority in a delegation from Congress or even in the Constitution itself. In categories roughly corresponding to these sources, the Supreme Court has concluded that federal court lawmaking comports with the Constitution where "Congress has given the courts the power to develop substantive law" 224 or where "a federal rule of decision is 'necessary to protect uniquely federal interests.'"225

\section{B. Jurisprudence Concerning Permitted Federal Common Law}

\section{Delegated Lawmaking}

Article I, Section 1 of the Constitution vests "[a]ll legislative Powers herein granted ... in a Congress of the United States." 226 This text, as the Supreme Court has emphasized in particular in recent

219 See supra note 214 and accompanying text.

220 Boyle v. United Techs. Corp., 487 U.S. 500, 504 (1988) (observing that, in certain instances, "state law is pre-empted and replaced . . . by federal law of a content prescribed (absent explicit statutory directive) by the courts-so-called 'federal common law' "); Tex. Indus., lnc. v. Radcliff Materials, lnc., 451 U.S. 630, 640 (1981) (observing that "the Court has recognized the need and authority in some limited areas to formulate what has come to be known as 'federal common law'").

221 Banco Nacional de Cuba v. Sabbatino, 376 U.S. 398, 426 (1964) (employing the term "federal judge-made law").

222 See Clark, supra note 2, at 1247 (describing federal common law as "rules of decision adopted and applied by federal courts that have the force and effect of positive federal law, but "whose content cannot be traced by traditional methods of interpretation to federal statutory or constitutional command." (quoting PAUL M. BATOR ET AL., HART \& Wechsler's The Federal Courts and the Federal System 863 (3d ed. 1988))); id. at 1248 ("By hypothesis, at least, federal common lawmaking begins where interpretation ends."); Field, supra note 29, at 890 (defining federal common law as "any rule of federal law created by a court (usually but not invariably a federal court) when the substance of that rule is not clearly suggested by federal enactments"). Professor Thomas Merrill is more expansive. He would identify federal common law as encompassing "any federal rule of decision that is not mandated on the face of some authoritative federal text" even if the rule "can be described as the product of 'interpretation' in either a conventional or an unconventional sense." Merrill, supra note 29 , at 5.

223 See Field, supra note 29, at 928 (arguing that "there must be a source of authority for any given federal common law rule"); Monaghan, supra note 29, at 12 (stating that federal courts "must point to some source, such as a statute, treaty, or constitutional provision, as authority for the creation of substantive federal law").

224 Tex. Indus., 451 U.S. at 640 (1981) (citing Wheeldin v. Wheeler, 373 U.S. 647, 652 (1963)).

225 Id. (quoting Sabbatino, 376 U.S. at 426).

226 U.S. ConsT. art. $1, \S 1$. 
years, "permits no delegation of those powers."227 Nonetheless, the separation of powers doctrine, which animates this observation, functions within the context of a need for a "workable government." 228 To this end, the Constitution does not require a "hermetic division among the Branches"229 or a limitation of the legislative, executive, and judicial branches to only their own specific and unique powers. ${ }^{230}$ Rather, "our constitutional system imposes upon the Branches a degree of overlapping responsibility, a duty of interdependence as well as independence the absence of which 'would preclude the establishment of a Nation capable of governing itself effectively.'" 231

With these overarching principles in mind, the Supreme Court has long recognized that the Constitution permits Congress to delegate certain of its lawmaking powers to the other coordinate branches of government. ${ }^{232}$ Echoing the broader observations above, the Court has explained that "in our increasingly complex society, replete with ever changing and more technical problems, Congress simply cannot do its job absent an ability to delegate power under broad general directives."233 The "non-delegation doctrine," which arises from the

227 Whitman v. Am. Trucking Ass'ns, 531 U.S. 457, 472 (2001) (citing Loving v. United States, 517 U.S. 748, 771 (1996)); see also Mistretta v. United States, 488 U.S. 361, 371-72 (1989) (observing that in light of Article 1, Section 1, "we long have insisted that 'the integrity and maintenance of the system of government ordained by the Constitution' mandate that Congress generally cannot delegate its legislative power to another Branch" (quoting Field v. Clark, 143 U.S. 649, 692 (1892))).

228 Youngstown Sheet \& Tube Co. v. Sawyer, 343 U.S. 579, 635 (1952) (Jackson, J., concurring).

229 See Mistretta, 488 U.S. at 381; see also id. at 380-81 (quoting James Madison's observation that separation of powers

"d[oes] not mean that these [three] departments ought to have no partial agency in, or no controul over the acts of each other," but rather "that where the whole power of one department is exercised by the same hands which possess the whole power of another department, the fundamental principles of a free constitution, are subverted."

(alterations in original) (quoting $T_{H E}$ FEDERALIST No. 47, at 325-26 (James Madison) (J. Cooke ed., 1961))); Morrison v. Olson, 487 U.S. 654, 693-94 (1988) ("[W]e have never held that the Constitution requires that the three branches of Government 'operate with absolute independence." (quoting United States v. Nixon, 418 U.S. 683, 707 (1974))); Buckley v. Valeo, 424 U.S. 1, 121 (1976) (per curiam) (observing that the Framers believed that a "hermetic sealing off of the three branches of Government from one another would preclude the establishment of a Nation capable of governing itself effectively").

230 See Mistretta, 488 U.S. at 381 (observing that the separation of powers doctrine reflects only "a carefully crafted system of checked and balanced power within each Branch").

231 Id. (quoting Buckley, 424 U.S. at 121).

232 See Loving v. United States, 517 U.S. 748, 758 (1996) (stating that the Court had "established long ago that Congress must be permitted to delegate to others at least some authority that it could exercise itself").

233 Mistretta, 488 U.S. at 372; see also Opp Cotton Mills, Inc. v. Adm'r of Wage \& Hour Div., Dep't of Labor, 312 U.S. 126, 145 (1941) (observing that “[i]n an increasingly complex society Congress obviously could not perform its functions if it were obliged to find all the facts subsidiary to the basic conclusions which support the defined legislative policy"). 
narrow text of Article I, Section 1, in other words, is not absolute. ${ }^{234}$ Rather, Congress may delegate what are in substance lawmaking powers, as long as it "lay[s] down by legislative act an intelligible principle to which the person or body authorized to [act] is directed to conform.'" 235

It is now established jurisprudence that Congress may delegate independent decision-making authority to federal courts. ${ }^{236}$ For over half a century, the Supreme Court has held that Congress may authorize federal court lawmaking for unresolved issues within the scope of a statute. This jurisprudence-as noted elsewhere ${ }^{237}$-traces its formal lineage to the Supreme Court's opinion in Textile Workers Union v. Lincoln Mills. ${ }^{238}$ There, the Court concluded that the legislative history of Section 301(a) of the Labor Management Relations Act ${ }^{239}$ reflected an implied congressional authorization for federal courts "to fashion a body of federal law for the enforcement of . . collective bargaining agreements." ${ }^{40}$ From this foundation, federal courts have developed an extensive body of wholly federal common law in the field of labor law. ${ }^{241}$

Congress has exercised its constitutional authority to delegate common law powers to federal courts on numerous occasions since the Lincoln Mills decision. In some cases, the delegation has been express. For example, Rule 501 of the Federal Rules of Evidence directly provides that testimonial privileges are to be "governed by the

234 See Peter H. Aranson et al., A Theory of Legislative Delegation, 68 CoRnell L. Rev. 1, $7-17$ (1982) (discussing the rise and eventual weakening of the non-delegation doctrine); Cynthia R. Farina, Statutory Interpretation and the Balance of Power in the Administrative State, 89 Colum. L. Rev. 452, 487 (1989) (analyzing the limits of the non-delegation doctrine).

235 Whitman v. Am. Trucking Ass'ns, 531 U.S. 457, 472 (2001) (second alteration in original) (quoting J.W. Hampton, Jr., \& Co. v. United States, 276 U.S. 394, 409 (1928)); see also Mistretta, 488 U.S. at 379 (observing that the non-delegation doctrine requires only that Congress provide sufficient guidance to permit a court "to ascertain whether the will of Congress has been obeyed" (quoting Yakus v. United States, 321 U.S. 414, 425-26 (1944))).

236 See, e.g., Touby v. United States, 500 U.S. 160, 165 (1991) (“Congress does not violate the Constitution merely because it legislates in broad terms, leaving a certain degree of discretion to . . judicial actors."); Tex. Indus., Inc. v. Radcliff Materials, lnc., 451 U.S. 630, 640 (1981) (finding one category of permissible federal common law where "Congress has given the courts the power to develop substantive law" (citing Wheeldin v. Wheeler, 373 U.S. 647, 652 (1963))); see also Merrill, supra note 29, at 40 (describing congressional authorizations of federal common law as "delegated lawmaking").

237 See Van Alstine, supra note 19, at 1282-83.

238353 U.S. 448 (1957).

23929 U.S.C. $\$ 185$ (a) (2000).

240 Lincoln Mills, 353 U.S. at 451.

241 See, e.g., Livadas v. Bradshaw, 512 U.S. 107, 121-22 (1994) ("[W]e have read the text of [Section] 301 not only to grant federal courts jurisdiction over claims asserting breach of collective-bargaining agreements but also to authorize the development of federal common-law rules of decision. ..." (footnote omitted)); Local 174, Teamsters v. Lucas Flour Co., 369 U.S. 95 (1962) (holding same). 
principles of the common law as they may be interpreted by the courts of the United States in the light of reason and experience."242

There are also abundant examples of implied statutory delegation. Federal legislation that impliedly authorizes federal common law includes the well-known cases of the Sherman Antitrust Act ${ }^{243}$ (acknowledged even by Justice Scalia ${ }^{244}$ ); the Labor Management Relations Act; 245 the Employee Retirement Income Security Act ("ERISA");246 and section 10(b) of the Securities Exchange Act of 1934. ${ }^{247}$ Other, less familiar, examples include certain aspects of the Federal Employers' Liability Act ("FELA");248 private causes of action

242 FED. R. Evid. 501 (2003); see also Jaffee v. Redmond, 518 U.S. 1, 8-9 (1996) (observing that Rule 501 "did not freeze the law governing the privileges of witnesses in federal trials at a particular point in our history, but rather directed federal courts to 'continue the evolutionary development of testimonial privileges' " (quoting Trammel v. United States, 445 U.S. 40, 47 (1980))); Trammel, 445 U.S. at 47 (noting that in the drafting of Rule 501 Congress rejected a more detailed proposal in favor of a general mandate to federal courts to develop the law based on common-law principles); Merrill, supra note 29, at 42 (observing that the "intent to delegate [in Rule 501] is unmistakable").

24315 U.S.C. $\$ 1$ (2000); see also State Oil Co. v. Khan, 522 U.S. 3, $20-21$ (1997) (observing that "the general presumption that legislative changes should be left to Congress has less force with respect to the Sherman Act in light of the accepted view that Congress 'expected the courts to give shape to the statute's broad mandate by drawing on commonlaw tradition' " (quoting Nat'l Soc'y of Prof'l Eng'rs v. United States, 435 U.S. 679, 688 (1978))).

244 See, e.g., Bus. Elecs. Corp. v. Sharp Elecs. Corp., 485 U.S. 717, 732 (1988) (Scalia, J., majority opinion) ("The Sherman Act adopted the term 'restraint of trade' along with its dynamic potential. lt invokes the common law itself, and not merely the static content that the common law had assigned to the term in 1890.").

24529 U.S.C. $\$ 185(\mathrm{a})$ (2000); see also supra notes $237-41$ and accompanying text.

24629 U.S.C. $\$ \S 1101-14$; see also Firestone Tire \& Rubber Co. v. Bruch, 489 U.S. 101, 110-11 (1989) (observing that in light of the text and legislative history of ERISA's fiduciary responsibility provisions, "we have held that courts are to develop a "federal common law of rights and obligations under ERISA-regulated plans'" (quoting Pilot Life Ins. Co.v. Dedeaux, 481 U.S. 41,56 (1987))).

24715 U.S.C. $\$ 78 \mathrm{j}(\mathrm{b})$; see also Musick, Peeler \& Garrett v. Employers Ins. of Wausau, 508 U.S. 286, 293-94 (1993) (holding that formulating the contours of Rule 10b-5 actions is a "task [that] . . Congress has left to us"); Blue Chip Stamps v. Manor Drug Stores, 421 U.S. 723, 737 (1975) (observing that in confronting private actions under Rule 10b-5, "we deal with a judicial oak which has grown from little more than a legislative acorn" and that "it would be disingenuous to suggest that either Congress in 1934 or the Securities and Excbange Commission in 1942 foreordained the present state of the law with respect to Rule 10b-5"); Merrill, supra note 29, at $45 \mathrm{n} .198$ (observing that "[a]nother prominent example of implied delegated lawmaking is the jurisprudence of 'deceptive and manipulative' practices that has emerged under section $10(\mathrm{~b})$ of the Securities Exchange Act of 1934").

248 See 45 U.S.C. $\$ 51$ (2000); see also Metro-North Commuter R.R. Co. v. Buckley, 521 U.S. 424, 429 (1997) (citing Justice Souter's concurrence in Consol. Rail Corp. v. Gottshall, 512 U.S. 532, 558 (1994) (Souter, J., concurring)); Consol. Rail, 512 U.S. at 558 (Souter, J., concurring) (observing that the duty of federal courts "in interpreting FELA . . . is to develop a federal common law of negligence . . . informed by reference to the evolving common law"). 
under 42 U.S.C. $\$ 1983 ;{ }^{249}$ the United States Housing Act of $1937 ; 250$ the Federal Fair Housing Act; ${ }^{251}$ and (most recently) the Torture Victim Protection Act of 1991 ("TVPA"). ${ }^{252}$

Moreover, from their very nature, broad, open-textured legislative standards imply a delegation of policymaking discretion to federal courts. ${ }^{253}$ As the Supreme Court observed in Northwest Airlines, Inc. $v$. Transport Workers Union, ${ }^{254}$ "[b] roadly worded . . statutory provisions necessarily have been given concrete meaning and application by a process of case-by-case judicial decision in the common-law tradition." 255 The flexible term "restraint of trade" in the Sherman

249 See Graham v. Satkoski, 51 F.3d 710, 713 (7th Cir. 1995) (holding that "[f]ederal common law governs the recovery of damages for complaints filed under 42 U.S.C. $\$ 1983^{\text {" }}$ (citing Carey v. Piphus, 435 U.S. 247, 257-59 (1978))); see also Cass R. Sunstein, Interpreting Statutes in the Regulatory State, 103 HaRv. L. Rev. 405, 421-22 (1989) (concluding that because " $[\S] 1983$ is silent on many important questions . . . the statute delegates power to make common law" (footnote omitted)).

25042 U.S.C. \$ 1437f(b) (2) (2000); see also Price v. Pierce, 823 F.2d 1114, 1119-20 (7th Cir. 1987) (holding with regard to certain aspects of contracts entered into by the Department of Housing and Urban Development that "the nature and feasibility of [such] contracts may depend in part on who can sue in the event of a breach. The issue is potentially so important ... that Congress, had it thought about the matter, would have wanted the question to be decided by federal courts. ...")

25142 U.S.C. $\$ \S 3533,3535,3601-19$; see also La. ACORN Fair Hous. v. LeBlanc, 211 F.3d 298, 301 (5th Cir. 2000) (holding with regard to a gap in the federal Fair Housing Act that "we must apply the federal common law to fill this gap in the FHA which Congress has left unanswered. Courts create federal common law when it is necessary to effectuate the intent behind a federal statute.").

25228 U.S.C. $\$ 1350$ (2000); see also Chiminya Tachiona v. Mugabe, 216 F. Supp. 2d 262, 267 (S.D.N.Y. 2002) (holding that the TVPA's lack of methodology requires courts to resort to federal common law); In re Estate of Marcos Human Rights Litig., 910 F. Supp. 1460,1469 (D. Haw. 1995) ("Because Congress in the TVPA offered no methodology as to how damages should be determined, federal courts are free to and should create federal common law to provide justice for any injury contemplated by . . treaties dealing with the protection of human rights."), affd sub nom. Hilao v. Estate of Marcos, 103 F.3d 767 (9th Cir 1996).

253 See McNally v. United States, 483 U.S. 350, 373 (1987) (Stevens, J., dissenting) ("The wide open spaces in statutes such as [The Sherman Act, The Civil Rights Acts, and the mail fraud statute] are most appropriately interpreted as implicit delegations of authority to the courts to fill in the gaps in the common-law tradition of case-by-case adjudication."); see also Merrill, supra note 29, at 43-46 (arguing that when Congress legislates broad standards or adopts a legal standard that is borrowed from the common law, this supports an inference that the courts may engage in "delegated lawmaking").

$254 \quad 451$ U.S. 77 (1981).

255 Id. at 95; see also Touby v. United States, 500 U.S. 160, 165 (1991) ("Congress does not violate the Constitution merely because it legislates in broad terms, leaving a certain degree of discretion to . . . judicial actors."); Mistretta v. United States, 488 U.S. 361, 415 (1989) (Scalia, J., dissenting) ("Once it is conceded . . that no statute can be entirely precise, and that some judgments, even some judgments involving policy considerations, must be left to ... the judges applying it, the debate over unconstitutional delegation becomes a debate not over a point of principle but over a question of degree."). 


\section{Antitrust Act ${ }^{256}$ represents a paradigmatic example of this phenomenon. ${ }^{257}$}

Congress of course may not delegate its entire legislative powers on a given subject. A naked legislative instruction that the federal courts create a "national uniform commercial code," for example, would certainly raise significant constitutional concerns. ${ }^{258}$ Nor does the mere existence of a relevant federal statute in a particular field of law authorize courts to make federal common law. ${ }^{259}$ Indeed, because Congress enjoys institutional advantages over federal courts in creating national policy, the Supreme Court has counseled a special "vigilance" in reviewing claims of delegated lawmaking powers. ${ }^{260}$

256 See supra notes 243-44 and accompanying text.

257 See Merrill, supra note 29, at 44-46 (analyzing the Sherman Act as a prime example of "implied delegated lawmaking" because of its open-ended provisions and the common law tradition on which it was based); Sunstein, supra note 249, at 421 (observing that the Supreme Court has interpreted the Sherman Act "as a delegation of policymaking power pursuant to quite open-ended criteria"). Other prominent examples include the protection of "personal privacy" under the Freedom of 1nformation Act and the requirement of "reasonable accommodations" under the Age Discrimination in Employment Act. See Harold J. Krent, The Failed Promise of Regulatory Variables, 73 WASH. U. L.Q. 1117, 1121 (1995) (citing these terms and arguing that "Congress in such statutes may be viewed as delegating authority to the courts to develop legislative principles through the common law").

258 See supra note 235 and accompanying text (describing Supreme Court precedent that Congress must at a minimum lay down an intelligible principle to guide the exercise of delegated power). The Supreme Court has only twice this century overturned statutes for violating the principle of non-delegation. See, e.g., A.L.A. Schechter Poultry Corp. v. United States, 295 U.S. 495, 542 (1935) (overturning the National Industrial Recovery Act because it conferred "virtually unfettered" discretion upon the President); Pan. Ref. Co. v. Ryan, 293 U.S. 388, 415 (1935) (overturning a statute that gave the President "unlimited authority to determine the policy and to lay down the prohibition [of interstate transportation of petroleum and petroleum products in excess of states' quotasl, or not to lay it down, as he may see fit"). The policies underlying non-delegation are still prevalent, however, and some commentators suggest that the doctrine has simply been replaced by procedural safeguards against unfettered delegation. See, e.g., Sandra B. Zellmer, The Devil, the Details, and the Dawn of the 21st Century Administrative State: Beyond the New Deal, 32 ARIz. ST. L.]. 941, 963 (2000) ("[I]n the post-New Deal, post-Administrative Procedure Act era, courts have been far more interested in ensuring that procedural safeguards cabin the exercise of delegated power so that those affected by agency action are protected from arbitrary and abusive decisions.").

259 See Atherton v. Fed. Deposit Ins. Corp., 519 U.S. 213, 218 (1997) ("[T] he existence of related federal statutes [does not] automatically show that Congress intended courts to create federal common-law rules ...." (citing Wallis v. Pan Am. Petroleum Corp., 384 U.S. $63,68(1966)))$.

260 See Mistretta, 488 U.S. at 383 ("In cases specifically involving the Judicial Branch, we have expressed our vigilance against [the] danger [ ] . . that the Judicial Branch neither be assigned nor allowed 'tasks that are more properly accomplished by [other] branches." (third alteration in original) (quoting Morrison v. Olson, 487 U.S. 654, 680-81 (1988))); see also City of Milwaukee v. Illinois, 451 U.S. 304, 312-13 (1981) ("The enactment of a federal rule in an area of national concern, and the decision whether to displace state law in doing so, is generally made not by the federal judiciary, purposefully insulated from democratic pressures, but by the people through their elected representatives in Congress."). For a comprehensive analysis of this issue, see Field, supra note 29, at 933-34 (analyzing the claim that Congress, because of its institutional advantages with regard to 
But a legislative enactment that both authorizes federal common law (whether expressly or implicitly) and marks the boundaries for the judicial exercise of that power does not contravene the Constitution. ${ }^{261}$ Because a congressional delegation represents a determination to create federal law by the federal institution constitutionally empowered to do so, it properly overcomes federalism concerns. ${ }^{262}$ By reasonably defining the substantive limits of discretion, such a delegation also satisfies separation of powers concerns over the unbridled judicial exercise of powers that the Constitution allocates to Congress. ${ }^{263}$ Indeed, where Congress has settled upon delegation as the best means of exercising federal lawmaking powers, the Supreme Court has " almost never felt qualified to second-guess Congress regarding the permissible degree of policy judgment that can be left to those . . . applying the law.' "264

\section{The "Enclaves" of Federal Common Law}

The second principal field of permitted federal common law derives directly from the structure and core principles of the Constitution. Just as the premise of Erie Railroad Co. v. Tompkins ${ }^{265}$ protects the reserved lawmaking authority of the states, the Supreme Court has reasoned that our federal system recognizes that certain areas are of "'uniquely federal interest." "266 Indeed, in the same term as Erie, the

fact-finding and the determination of broad national policies, "is generally better equipped to generate a new scheme of rules than are the courts").

261 See Mistretta, 488 U.S. at 372-73 (holding with regard to delegation in general that "this Court has deemed it "constitutionally sufficient if Congress clearly delineates the general policy, the public agency which is to apply it, and the boundaries of this delegated authority." (quoting Am. Power \& Light Co. v. SEC, 329 U.S. 90, 105 (1946))).

262 Perhaps the clearest expression of the propriety of federal court lawmaking to fulfill the intent of Congress comes from United States v. Little Lake Misere Land Co., 412 U.S. 580 (1973):

[T] he inevitable incompleteness presented by all legislation means that interstitial federal lawmaking is a basic responsibility of the federal courts. "At the very least, effective Constitutionalism requires recognition of power in the federal courts to declare, as a matter of common law or 'judicial legislation,' rules which may be necessary to fill in interstitially or otherwise effectuate the statutory patterns enacted in the large by Congress."

Id. at 593 (quoting Paul J. Mishkin, The Variousness of "Federal Law": Competence and Discretion in the Choice of National and State Rules for Decision, 105 U. PA. L. Rev. 797, 800 (1957)).

263 See Merrill, supra note 29, at 41 (arguing that congressional delegation of lawmaking powers to federal courts does not violate the separation of powers doctrine if it is "specifically intended and the area of delegation is reasonably circumscribed"); see also Van Alstine, supra note 19, at 1285-86 (agreeing with Professor Merrill's conclusion).

264 Whitman v. Am. Trucking Ass'ns, 531 U.S. 457, 474-75 (2001) (quoting Mistretta, 488 U.S. at 416) (Scalia, J., dissenting)).

265304 U.S. 64 (1938).

266 See Boyle v. United Techs. Corp., 487 U.S. 500, 504 (1988) (observing that certain matters of "uniquely federal interest [ ]" are "so committed by the Constitution" to federal law that state law is preempted as needed by rules of federal common law (quoting Tex. lndus., Inc. v. Radcliff Materials, Inc., 451 U.S. 630, 640 (1981) and citing United States v. 
Court applied its own rule of federal common law to a dispute over the apportionment of water in an interstate stream. ${ }^{267}$ In the following decade, the Court likewise emphatically declared that notwithstanding Erie, there was "no purpose or effect for broadening state power over matters essentially of federal character. . ."268

The Court has famously described this form of federal common law as the "enclaves of federal judge-made law." 269 As explained in Texas Industries, Inc. v. Radcliff Materials, Inc., ${ }^{270}$ these enclaves generally distill into four categories: disputes "concerned with the rights and obligations of the United States;" 271 interstate disputes "implicating the conflicting rights of States . .."272 (such as the water rights matters noted above) $; 273$ controversies touching on the nation's "relations with foreign nations;" 274 and admiralty cases. ${ }^{275}$

The common theme among these categories is that they "so vitally affect[ ] interests, powers and relations of the Federal Government as to require uniform national disposition . . ."276 The Supreme Court has reasoned that the Constitution disables states

Kimbell Foods, Inc., 440 U.S. 715, 726-29 (1979); Banco Nacional de Cuba v. Sabbatino, 376 U.S. 398, 426-27 (1964); Howard v. Lyons, 360 U.S. 593, 597 (1959); Clearfield Trust Co. v. United States, 3 I8 U.S. 363, 366-67 (1943); D'Oench, Duhme \& Co. v. Fed. Deposit Ins. Corp., 315 U.S. 447, 457-58 (1942))).

267 See Hinderlider v. La Plata River \& Cherry Creek Ditch Co., 304 U.S. 92, 110 (1938) (recognizing the Court's jurisdiction over "controversies concerning rights in interstate streams," which are "question[s] of 'federal common law'"); see also Illinois v. City of Milwaukee, 406 U.S. 91, 102-04 (1972) (holding that federal common law properly applied to an interstate dispute over air and water rights); cf. City of Milwaukee v. Illinois, 45I U.S. 304, 313-14 (1981) (holding same, unless Congress has superceded federal common law via statute).

268 United States v. Standard Oil Co., 332 U.S. 301, 307 (1947).

269 Sabbatino, 376 U.S. at 426-27.

270451 U.S. 630 (1981).

$271 I d$. at 641 (citing United States v. Little Lake Misere Land Co., 412 U.S. 580, 592-93 (1973) and Clearfield Trust, 318 U.S. at 366-67); see also Boyle, 487 U.S. at 504 (observing that "obligations to and rights of the United States under its contracts are governed exclusively by federal law"); Westfall v. Erwin, 484 U.S. 292, 295 (1988) ("[T] his Court has held that the scope of absolute official immunity afforded federal employees is a matter of federal law, 'to be formulated by the courts in the absence of legislative action by Congress.' " (quoting Howard v. Lyons, 360 U.S. 564, 597 (1959))).

272 See Tex. Indus., 451 U.S. at 64I (citing, inter alia, Hinderlider, 304 U.S. at 110).

273 See supra note 267 and accompanying text.

274 See Tex. Indus., 451 U.S. at 641 (citing, inter alia, Sabbatino, 376 U.S. 398)

275 See id. (citing Edmonds v. Compagnie Generale Transatlantique, 443 U.S. 256 (1979) and Fitzgerald v. United States Lines Co., 374 U.S. 16 (1963)); see also The Lottawanna, 88 U.S. (21 Wall.) 558, 575 (1874) (noting that the Constitution extends the Court's jurisdiction "to all cases of admiralty and maritime jurisdiction" and concluding that federal common law is appropriate in this field because placing "the rules and limits of maritime law under the disposal and regulation of the several States . . would have defeated the uniformity and consistency at which the Constitution aimed on all subjects of a commercial character affecting the intercourse of the States with each other or with foreign states").

276 United States v. Standard Oil Co., 332 U.S. 301, 307 (1947). 
from exerting lawmaking authority over the "enclaves" either because the matters, by their nature, involve the sovereign dignity of the United States or "because the interstate or international nature of the controversy makes it inappropriate for state law to control." $277 \mathrm{Be}-$ cause the Constitution and other federal law so strongly consign such matters to federal control as to trump state law, it is the constitutional responsibility of the federal courts to supply their own federal common-law rule, absent contrary directives from Congress. ${ }^{278}$ Where this is the case, the Supreme Court has made clear that federal common law is appropriate even where the dispute is solely between private parties. ${ }^{279}$

A strong federal interest in a particular subject, without more, is insufficient to sanction the application of federal common law. ${ }^{280}$ Rather, there also must be a significant conflict between a federal policy or interest and the operation of state law. ${ }^{281}$ Nonetheless, where a particular field of law is one of uniquely federal concern, " $[t]$ he conflict with federal policy need not be as sharp as that which must exist for ordinary preemption when Congress legislates 'in a field which the States have traditionally occupied.' "282 And where the federal interest requires a uniform rule, such as with the contractual obligations of the United States, "the entire body of state law applicable to the area conflicts and is replaced by federal rules." 283

Disputes implicating matters of foreign affairs present perhaps the best-and, for present purposes, certainly the most impor-

277 Tex. Indus., 451 U.S. at 641.

278 See cases cited supra note 266; see also Clark, supra note 211, at 1452-57 (analyzing the four enclaves of federal common law and concluding that, with the possible exception of admiralty law, they are consistent with the constitutional structure and federal lawmaking procedures).

279 See Boyle v. United Techs. Corp., 487 U.S. 500, 506 (1988); see also Buckman Co. v. Plaintiffs' Legal Comm., 531 U.S. 341, 348 (2001) (ruling that the federal statutory scheme empowering the Food and Drug Administration to deter fraud creates a federal common law preemption against state law fraud-on-the-FDA claims); Kamen v. Kemper Fin. Servs., Inc., 500 U.S. 90, 97-98 (1991) (holding that federal common law governs derivative shareholder actions based on federal law, absent express congressional provisions to the contrary).

280 See, e.g., Miree v. DeKalb County, 433 U.S. 25, 31 (1977) (holding that federal common law need not necessarily apply to a contract dispute relating to the use of land adjacent to an airport simply because the federal government "has a substantial interest in regulating aircraft travel and promoting air travel safety").

281 See Atherton v. Fed. Deposit Ins. Corp., 519 U.S. 213, 218 (1997) ("[N]ormally, when courts decide to fashion rules of federal common law, 'the guiding principle is that a significant conflict between some federal policy or interest and the use of state law ... must first be specifically shown." (second alteration in original) (quoting Wallis v. Pan Am. Petroleum Corp., 384 U.S. 63, 68 (1966))); see also Boyle, 487 U.S. at 507 (same).

282 Boyle, 487 U.S. at 507 (quoting Rice v. Santa Fe Elevator Corp., 331 U.S. 218, 230 (1947)). The interaction of the statutory preemption doctrine and federal common law is discussed in greater detail below. See discussion infra Part 11.C.

283 See Boyle, 487 U.S. at 508. 
tant ${ }^{284}$-illustration of this reasoning. ${ }^{285}$ As the Supreme Court explained in its foundational pronouncement in Banco Nacional de Cuba v. Sabbatino, ${ }^{286}$ the very nature of core issues of foreign affairs requires the displacement of state law by a uniform federal law solution: "[W]e are constrained to make it clear that an issue concerned with a basic choice regarding the competence and function of the Judiciary and the National Executive in ordering our relationships with other members of the international community must be treated exclusively as an aspect of federal law." 287

As to the specific issue in dispute, the Sabbatino Court concluded that the force of sovereign acts of foreign nations in disputes before U.S. courts (the so-called "act of state doctrine") was a matter of federal common law. ${ }^{288}$ In doing so, the Court also specifically addressed the common concerns about the limits on federal court lawmaking, declaring: "It seems fair to assume that the Court did not have rules like the act of state doctrine in mind when it decided Erie [Railroad] Co. v. Tompkins." 289 From this foundation, lower federal courts have determined that federal common law is appropriate for a wide range of issues implicating the foreign affairs of the United States. ${ }^{290}$

284 See infra notes 533-46 and accompanying text (analyzing the significance of the foreign affairs enclave of federal common law for the corresponding powers of federal courts over law within the scope of treaties).

285 See Clark, supra note 2, at 1292 (describing the foreign affairs enclave as “[o]ne of the more prominent modern enclaves of federal common law"); Goldsmith, supra note 20, at 1632 (asserting that "there is a remarkable consensus about the legitimacy of the federal common law of foreign relations").

286376 U.S. 398 (1964).

287 Id. at 425.

288 See id. at $426-27$.

289 Id. at 425.

290 See, e.g., Republic of the Philippines v. Marcos, 806 F.2d 344, 352-54 (2d Cir. 1986) (holding that "an action brought by a foreign government against its former head of state arises under federal common law because of the necessary implications of such an action for United States foreign relations"); In re World War II Era Japanese Forced Labor Litig., 114 F. Supp. 2d 939, 943 (N.D. Cal. 2000) (holding that a U.S. solider's claim against Japan for World War 11 era imprisonment "implicate[s] the federal common law of foreign relations and, as such, give[s] rise to federal jurisdiction"); United States v. Schofield, 197 F.R.D. 6, 9 (D.D.C. 2000) (holding, in an action for unpaid rent on a foreign embassy, that "[a]lthough the congressional regulation of foreign missions is silent on the issue of leasing, this Court has little hesitation in finding federal common law to be applicable" because of the foreign affairs implications of the case); Torres v. S. Peru Copper Corp., 965 F. Supp. 895, 898-99 (S.D. Tex. 1995) (holding that an environmental waste action by citizens of Peru against a Delaware corporation, whose principal place of business was in Peru, "[arose] under the federal common law of international relations" because the "international nature of the controversy makes it inappropriate for state law to control' " (quoting Tex. Indus., Inc. v. Radcliff Materials, Inc., 451 U.S. 630, 641 (1981))); Sequihua v. Texaco, Inc., 847 F. Supp. 61, 62 (S.D. Tex. 1994) (holding in a pollution-related action by Ecuadorean citizens that "[c]learly, such issues of international relations are incorporated into federal common law" and that "there are essential elements of Plaintiffs' claims which, if 'well-pleaded,' require the application and resolution of the federal common law regarding foreign relations"); Grynberg Prod. Corp. v. British Gas, P.L.C., 817 F. Supp. 1338, 


\section{Federal Common Law and the Preemption Doctrine}

A full understanding of the federal courts' lawmaking powers finally requires an appreciation of the subtle interaction between federal common law and the notion of federal preemption. It is of course the very premise of the Supremacy Clause that Congress is authorized to displace state law through an express exercise of its Article I delegated powers, ${ }^{291}$ as are the treaty-lawmakers under their Article Il powers. ${ }^{292}$ Where the related federal law interests so require, such an exercise of federal power may also create a federal law foundation for interstitial lawmaking by federal courts. ${ }^{293}$

Often the effect of preemption is merely negative in form, for example, where a federal court determines that state law rules of decision are displaced to the extent that they conflict with formal norms of federal law. The full preemptive force of federal law is much more expansive, however, than this narrow notion of "conflict preemption." 294 Even in the absence of a direct conflict, a federal court may invalidate state law if it stands as an "obstacle" to the fulfillment of federal law objectives. ${ }^{295}$ In what one might view as a mild form of federal common law, in other words, a federal court extends the reach of the express terms of positive federal law to displace state law. Here,

1355-59 (E.D. Tex. 1993) (citing Sabbatino, 376 U.S. 398 (1964), and holding, in a purely private dispute over rights to oil in Kazakhstan, that "a well-pleaded complaint for specific performance would require the nullification of and interference with the relationship between Kazakhstan and its resources. Claims of right to title in foreign lands present questions of international relations governed exclusively by federal law").

291 See Crosby v. Nat'l Foreign Trade Council, 530 U.S. 363, 372-73 (2000) (citing the Supremacy Clause and observing that "[a] fundamental principle of the Constitution is that Congress has the power to preempt state law"); Boyle v. United Techs. Corp., 487 U.S. 500,504 (1988) (noting that state law is preempted in the case of "a clear statutory prescription" (citing Jones v. Rath Packing Co., 430 U.S. 519, 525 (1977) and Rice v. Santa Fe Elevator Corp., 331 U.S. 218, 230 (1947))).

292 See supra notes 86-89 and accompanying text. The Supreme Court confirmed this proposition most recently in American Insurance Ass'n v. Garamendi. See 123 S. Ct. 2374, 2387 (2003) (observing that treaties "are fit to preempt state law"). Garamendi also recognized that the President has the power to displace state law through sole executive agreements. See id. at 2390-91; see also infra notes 524-27 and accompanying text.

293 Cf. Merrill, supra note 29, at 36 (describing a class of proper federal common law as "preemptive lawmaking" in which a court "carr[ies] out the original intentions of the enacting body . . . by asking what collateral or subsidiary rules are necessary in order to effectuate or to avoid frustrating the specific intentions of the draftsmen").

294 See Crosby, 530 U.S. at 372-73 \& n.6 (employing this term with respect to statutory preemption); see also Boyle, 487 U.S. at 504 (observing that federal law preempts state law where there is a "direct conflict between federal and state law").

295 See Crosby, 530 U.S. at 373 (observing that federal law preempts state law where the challenged state law "stands as an obstacle to the accomplishment and execution of the full purposes and objectives of Congress'" (quoting Hines v. Davidowitz, 312 U.S. 52, 67 (1941) (first alteration in original))); see also Burks v. Lasker, 441 U.S. 471, 479 (1979) ("[F] ederal courts must be ever vigilant to insure that application of state law poses "no significant threat to any identifiable federal policy or interest ... ." (quoting Wallis v. Pan Am. Petroleum Corp., 384 U.S. 63, 68 (1966))) . 
however, the court does so based on its independent judgment that a state law poses an improper obstacle ${ }^{296}$ to the broader, unarticulated purposes or intended effects of federal law. ${ }^{297}$

Moving along the spectrum of preemption, federal courts may find a basis for a more direct exercise of lawmaking powers in the case of so-called "field preemption." 298 The legislative and administrative regulation of a particular field of law may be so pervasive, or Congress may have so clearly expressed its intent to "occupy the field," 299 as to compel the conclusion that "'Congress left no room for the States to supplement it." "300 When, then, a disputed issue lacks a legislative solution in the field, the federal law interests often will require federal courts-absent contrary positive law guidance-to fill the gap with a rule of federal common law. ${ }^{301}$

296 As the Supreme Court emphasized only this past term, this "obstacle preemption" is particularly powerful in the field of foreign affairs. See Garamendi, $123 \mathrm{~S}$. Ct. at 2386-90. For obvious reasons, the Court's opinion in Garamendi will be valuable in our analysis below. See infra notes 524-27 and accompanying text.

297 See Crosby, 530 U.S. at 373 (observing that " $[\mathrm{w}]$ hat is a sufficient obstacle is a matter of judgment, to be informed by examining the federal statute as a whole and identifying its purpose and intended effects"); see also Merrill, supra note 29, at 36 (arguing that a federal court engages in "preemptive lawmaking" not on the basis of "the specific intentions of the draftsmen, but by asking what collateral or subsidiary rules are necessary in order to effectuate or to avoid frustrating the specific intentions of the draftsmen").

298 See Crosby, 530 U.S. at 372-73 \& n.6 (employing the term "field preemption" and examining statutory preemption in general). The traditional presumption against preemption applies as well to assertions of "field preemption." See, e.g., Pac. Gas \& Elec. Co. v. State Energy Res. Conservation \& Dev. Comm'n, 461 U.S. 190, 206 (1983) (holding that federal legislation does not preempt areas of state law that traditionally fall within state police powers, unless such preemption is clearly the purpose of the legislation); Rice $v$. Santa Fe Elevator Corp., 331 U.S. 218, 230 (1947) (stating that congressional occupation of the field is not to be presumed "in a field which the States have traditionally occupied"). For more on the presumption against preemption, see infra notes 463-67 and accompanying text.

299 See Crosby, 530 U.S. at 372 ("When Congress intends federal law to 'occupy the field,' state law in that area is preempted.").

300 English v. Gen. Elec. Co., 496 U.S. 72, 79 (1990) (quoting Rice, 331 U.S. at 230); see also, e.g., California v. ARC Am. Corp., 490 U.S. 93, 100-01 (1989) (discussing situations in which state law is entirely preempted because Congress intended federal law to occupy the field); Hines, 312 U.S. at 66-67 (holding with regard to the issue of immigration that "the federal government, in the exercise of its superior authority in this field, has enacted a complete scheme of regulation" and thus "states cannot, inconsistently with the purpose of Congress, conflict or interfere with, curtail or complement, the federal law, or enforce additional or auxiliary regulations").

301 A good example is the field of employee pension plans, which is preempted by ERISA. See McGurl v. Trucking Employees of N. Jersey Welfare Fund, Inc., 124 F.3d 471, 481 (3d Cir. 1997) (observing, in connection with the law ERISA preempted, that " [w] here state law is preempted and no specific federal provision governs, a court is forced to make law or leave a void where neither state nor federal law applies. In such a situation it is a reasonable inference that Congress intended some law, and therefore federal law, to apply'" (alteration in original) (quoting Wayne Chem., Inc. v. Columbus Agency Serv. Corp., 426 F. Supp. 316, 322 (N.D. Ind. 1977))). This quotation most likely 
The message here is that federal law interests reflected in a formal exercise of federal power may create the foundation for interstitial federal court lawmaking. This foundation may also reflect a noteworthy overlap with the notion of implied delegation. In some cases, federal court lawmaking powers may arise from a corresponding, if imperfectly expressed, authorizing intent of Congress. ${ }^{302}$ But the same conclusion often may issue from the broader federal interests reflected in federal legislation, together with the conflict that would arise from the operation of state law. In parallel with those constitutionally-created areas of "uniquely federal interests," 303 in other words, Congress may create such predominantly forceful federal law interests that the federal judiciary has the implied authority to fill gaps in the regulatory scheme as they emerge over time.

A final note is appropriate here concerning the special role of federal courts in protecting federal interests in the field of foreign affairs. At various times in the last half-century, the Supreme Court has cautiously accepted the notion of "dormant" federal foreign affairs powers as a justification for preemption of state law. ${ }^{304}$ In recent years, however, this proposition has generated substantial controversy, ${ }^{305}$ and the Court's present disposition is unclear. ${ }^{306}$

derives from an even earlier law review article. See Note, The Federal Common Law, 82 Harv. L. REv. 1512, 1522 (1969).

302 See supra notes 243-57 and accompanying text.

303 See discussion supra Part II.B.2 (analyzing the recognized "enclaves" of federal common law).

304 See infra notes 515-17 and accompanying text (discussing Supreme Court precedent on the notion of a "dormant foreign affairs" power and a "dormant foreign Commerce Clause").

305 See Jack L. Goldsmith, The New Formalism in United States Foreign Relations Law, $70 \mathrm{U}$. Colo. L. Rev. 1395, I426-27 (1999) (arguing that recent Supreme Court case law demonstrates that the Court is rejecting dormant foreign affairs preemption); Peter J. Spiro, Foreign Relations Federalism, 70 U. CoLo. L. REv. 1223, 1246-52 (1999) (providing functional reasons for maintaining federal exclusivity). Compare Bradley \& Goldsmith, supra note 20 , at 864-68 (arguing that " $[\mathrm{m}]$ odern case support for dormant foreign relations preemption is . . uncertain") and Goldsmith, supra note 20, at 1649-58 (providing tenuous historical examples of dormant foreign relations preemption), with Koh, supra note 20, at 1848-50 (argning that federal courts are "more appropriate adjudicators to rule on international matters").

306 The principal case recognizing the federal government's dormant powers in the field of foreign affairs is Zschernig v. Miller, 389 U.S. 429 (1968), which holds that federal law preempts any state action that has more than an "incidental or indirect effect" "on the nation's foreign affairs, even if the state action does not conflict with any formal articulations of federal policy. See id. at 432 (quoting Clark v. Allen, 331 U.S. 503, 517 (1947)). But see Am. Ins. Ass'n v. Garamendi, 123 S. Ct. 2374, 2388-89 (2003) (observing that it is a "fair question" whether Zschernig's field preemption approach to the dormant foreign affairs power is appropriate); $i d$. at 2400 (Ginsburg, J., dissenting) ("We have not relied on Zschernig since it was decided, and I would not resurrect that decision here."); Barclays Bank PLC v. Franchise Tax Bd., 512 U.S. 298, 320-24 (1994) (failing to implement Zschernig's articulation of a "dormant foreign affairs" power with respect to California's franchise tax as applied to foreign companies). 
This Article will engage this controversy in greater depth below. ${ }^{307}$ It will suffice at this point to repeat that treaties reflect a formal exercise of federal lawmaking power. ${ }^{308}$ As a result, the lawmaking powers of federal courts under treaties will not depend on the "dormant" constitutional powers of the political branches. ${ }^{309}$

\section{III \\ Treaty Power, Judicial Power, and Delegated Federal COURT LaWMaking}

A. The Relationship of the Treaty Power to the Judicial Power

The analysis in Part I above revealed that self-executing treaties now regulate broad and expanding fields of the U.S. legal landscape. On a seemingly isolated path, Supreme Court jurisprudence-as illustrated in Part II-continues to emphasize in the progeny of Erie Railroad Co. v. Tompkins ${ }^{310}$ the limits on the lawmaking powers of federal courts. As an increasing share of lawmaking activity occurs within the shadow of U.S. foreign relations, however, the context for an analysis of the federal courts' lawmaking powers is changing. In other words, as federal law increasingly expands the areas of uniquely federal concern, ${ }^{311}$ we face increasing strains on the accepted wisdom about the boundaries of federal common law. This mounting tension provides the setting for the following analysis of federal court lawmaking powers in areas governed by self-executing treaties.

\section{The Judicial Power and the Treaty Power}

The first step in this analysis is to understand in detail the relationship between the treaty power of Article $\mathrm{II}^{312}$ and the "judicial Power" of Article 1II. ${ }^{313}$ The Supremacy Clause in Article VI formally designates treaties, along with other forms of federal law, as the "su-

\footnotetext{
307 See infra notes 515-20 and accompanying text (discussing the exclusive federal lawmaking power over foreign relations).

308 See infra notes $337-46$ and accompanying text (discussing the treaty power as a separate and independent delegated power to create federal law).

309 For an argument in favor of a more nuanced understanding of the "dormant treaty power," see Swaine, supra note 51, at 1254-74.

310304 U.S. 64 (1938).

311 See Banco Nacional de Cuba v. Sabbatino, 376 U.S. 398, 425 (1964) (declaring that issues "concerned with a basic choice regarding the competence and function of the Judiciary and the National Executive in ordering our relationships with other members of the international community must be treated exclusively as an aspect of federal law"); see also supra notes $279-85$ and accompanying text (analyzing the "foreign affairs enclave" of federal common law).

312 See U.S. Const. art. II, § 2, cl. 2.

313 See id. art. III, $\$ 2$, cl. 1 .
} 
preme Law of the Land." ${ }^{14}$ From this provision, the Supreme Court has long reasoned that, when their substance so directs, ${ }^{315}$ treaties may take effect as federal law, even without Article I implementing legislation. ${ }^{316}$ We have also seen that Article III, Section 2, affirms that the "judicial Power" of federal courts extends to treaties as well. ${ }^{317}$ In combined effect, the express inclusion of treaties within both Article III and Article VI "altered-or made irrelevant-for domestic purposes those attributes of treaties that distinguished them from laws: it made them operative on individuals and enforceable in the courts by individuals." 318

As a result of these constitutional principles, treaties proceed from essentially the same foundation of supreme federal law as does Article I legislation. ${ }^{319}$ Thus, the Supreme Court has consistently described self-executing treaties as "equivalent to an act of the legislature" 320 and as legal vehicles that "partake of the nature of municipal law ... in the same category as other laws of Congress." 321

314 Id. art. VI, cl. 2; see also supra notes 50-52 and accompanying text (analyzing this clause of the Constitution with regard to treaties).

315 See supra notes 90-94 and accompanying text (analyzing the circumstances under which a treaty may not be self-executing).

316 See supra notes 78-89 and accompanying text (analyzing Supreme Court precedent, in particular Foster v. Neilson, 27 U.S. 253 (1829), overruled on other grounds by United Staes v. Percheman, 32 U.S. (Pet.) 51, 52 (1833), on the direct effect of self-executing treaties).

317 See U.S. Const. art. III, $\S 2$, cl. 1 ("The judicial Power shall extend to all Cases, in Law and Equity, arising under . . . Treaties made, or which shall be made" under the authority of the United States). Because they represent the "Law of the Land," id. art. VI, cl. 2, such treaties must also fall within the President's Article II, Section 3 obligation to "take Care" that federal laws are "faithfully executed," see U.S. Const. art. 11, § 3; see also Curtis A. Bradley, Chevron Deference and Foreign Affairs, 86 VA. L. REv. 649, 655 (2000) (observing that self-executing treaties "presumably are also part of the 'Laws' referred to in Article Il's Take Care Clause").

318 Vázquez, supra note 87 , at I108-09.

319 See supra notes 83-85 and accompanying text (analyzing Supreme Court authority holding, based on the Supremacy Clause, that treaties take effect as federal law just like Article I legislation); see also Whitney v. Robertson, 124 U.S. 190, 194 (1888) (declaring that where treaty provisions "are self-executing, that is, require no legislation to make them operative ... they have the force and effect of a legislative enactment"); Strother v. Lucas, 37 U.S. 410, 438-39 (1838) ("Treaties are the law of the land, and a rule of decision in all courts."); Foster, 27 U.S. at 314 (observing that a treaty "is . . to be regarded in Courts of justice as equivalent to an act of the legislature, whenever it operates of itself without the aid of any legislative provision").

320 Foster, 27 U.S. at 314; see, e.g., Chae Chan Ping v. United States (The Chinese Exclusion Case), 130 U.S. 581, 600 (1889) (

By the Constitution, laws made in pursuance thereof, and treaties made under the authority of the United States, are both declared to be the supreme law of the land .... If the treaty operates by its own force, and relates to a subject within the power of Congress, it can be deemed in that particular only the equivalent of a legislative act ....

); Whitney, 124 U.S. at 194 (concluding that a self-executing treaty has the "force and effect of a legislative enactment").

321 The Head Money Cases, 112 U.S. 580, 598 (1884). 
This does not mean that treaties have precisely the same constitutional status and function as statutes, but only that they have no less force as federal law. When a treaty "addresses itself" to federal courts, ${ }^{322}$ therefore, Article III requires that the courts apply the treaty as a federal rule of decision just as they would a statute or any other form of enforceable federal law. Indeed, as noted above, ${ }^{323}$ from its earliest confrontation with the subject, the Supreme Court has confirmed the "obligation" of federal courts to apply treaties in cases properly before them; for when a treaty creates individual rights, it "as much binds those rights and is as much to be regarded by the court as an act of [C] ongress." 324

Because self-executing treaties fall within the judicial power of Article III, federal courts have the final authority over their interpretation and application. ${ }^{325}$ Even the issue of whether a treaty is designed to be self-executing at all is a judicial question. ${ }^{326}$ Thus, just like Article I legislation, once proposed legal standards have passed into formal federal law, it becomes the province of the courts, as Marbury $v$. Madison famously declared, "to say what the law is," 327 which of its nature includes the power to "expound and interpret" the elements of positive law. ${ }^{328}$

322 Cf. Foster, 27 U.S. at 314 (suggesting the notion of a treaty "address[ing] itself to the political . . . department" as a means of determining whether a treaty is non-selfexecuting).

323 See supra note 143 and accompanying text.

324 United States v. Schooner Peggy, 5 U.S. (1 Cranch) 103, 110 (1801).

325 See Japan Whaling Ass'n v. Am. Cetacean Soc'y, 478 U.S. 221, 230 (1986) (holding that "the courts have the authority to construe treaties"); Kolovrat v. Oregon, 366 U.S. 187, 194 (1961) (observing that "courts interpret treaties for themselves"); Ware v. Hylton, 3 U.S. (3 Dall.) 199, 239 (1796) (holding with regard to the interpretation of a disputed provision of a self-executing treaty that "the courts, in which the cases arose, were the only proper authority to decide, whether the case was within this article of the treaty, and the operation and effect of it"); British Caledonian Airways Ltd. v. Bond, 665 F.2d 1153, 1160 (D.C. Cir. 1981) ("In general, courts in the United States have exclusive authority to interpret an international agreement to which the United States is a party for the purpose of applying it in litigation as the domestic law of the United States."); see also RESTATEMENT of FOREIGN Relations, supra note 75, §112(2) ("The determination and interpretation of international law present federal questions and their disposition by the United States Supreme Court is conclusive for other courts in the United States."). Nothing prevents a state court from interpreting a treaty as an issue of federal law. See, e.g., Sei Fujii v. State, 242 P.2d 617, 619-22 (Cal. 1952) (interpreting a provision in the Charter of the United Nations). Such instances are rare, however, for the simple reason that federal courts have original jurisdiction over treaty cases, see 28 U.S.C. $\$ 1331$ (2000), and defendants have an automatic right of removal from state courts, see id. $\$ 1441$ (b).

326 See British Caledonian Airways, 665 F.2d at 1160 (holding that "whether a given treaty is self-executing or requires special implementing legislation to give force and effect to its provisions is primarily a domestic question of construction for the courts"); Diggs v. Richardson, 555 F.2d 848, 851 (D.C. Cir. 1976) (same).

327 Marbury v. Madison, 5 U.S. (1 Cranch) 137, 177 (1803).

328 See id. 
With regard to statutes, this recognized role for courts leads directly to the principle that even the interpretive opinions of a later Congress are of "very little, if any, significance." "329 The same applies for treaties. Although foreign affairs considerations may require respect for the reasonable interpretive views of the executive branch, ${ }^{330}$ the Supreme Court has declared itself the final arbiter of the meaning of self-executing treaties. ${ }^{331}$ Even the political branches have acknowledged this principle, from their earliest jurisdictional statutes ${ }^{332}$ to the current day. ${ }^{333}$

329 United States v. Southwestern Cable Co., 392 U.S. 157, 170 (1968) (quoting Rainwater v. United States, 356 U.S. 590, 593 (1958)); see also South Dakota v. Yankton Sioux Tribe, 522 U.S. 329, 355 (1998) ("We have often observed . . . that "the views of a subsequent Congress form a hazardous basis for inferring the intent of an earlier one.' (quoting, inter alia, United States v. Phila. Nat'l Bank, 374 U.S. 321, 348-49 (1963))); Cent. Bank of Denver v. First Interstate Bank of Denver, 511 U.S. 164, 185-86 (1994) (" [W] have observed on more than one occasion that the interpretation given by one Congress . . . to an earlier statute is of little assistance in discerning the meaning of that statute." (alteration in original) (quoting Pub. Employees Ret. Sys. of Ohio v. Betts, 492 U.S. 158, 168 (1989))); United States v. Price, 361 U.S. 304, 313 (1960) (holding that the views of subsequent Congresses provide too "slender a reed" on which to base reliable inferences regarding a statute).

330 See El Al Isr. Airlines, Ltd. v. Tsui Yuan Tseng, 525 U.S. 155, 168 (1999) (observing that " $[\mathrm{r}]$ espect is ordinarily due the reasonable views of the Executive Branch concerning the meaning of an international treaty" and noting a prior case which held that interpretive views of executive agencies charged with the enforcement of a treaty are entitled to great weight).

331 See United States v. Alvarez-Machain, 504 U.S. 655, 667 (1992) (observing that if a treaty is self-executing, "it would appear that a court must enforce it on behalf of an individual regardless of the offensiveness of the practice of one nation to the other nation"); Kolovrat v. Oregon, 366 U.S. 187, 194 (1961) (observing that, although the interpretive views of the executive branch are entitled to deference, "courts interpret treaties for themselves"); Ware v. Hylton, 3 U.S. (3 Dall.) 199, 239 (1796) (concluding, with regard to the interpretation of a treaty provision, that the courts "were the only proper authority to decide, whether the case was within this article of the treaty, and the operation and effect of it"). In a broader sense, the Court has declared that the simple presence of foreign affairs considerations does not mean that a matter is a political question beyond the competence of courts. See Baker v. Carr, 369 U.S. 186, 211 (1962) ("[I]t is error to suppose that every case or controversy which touches foreign relations lies beyond judicial cognizance.").

332 The first jurisdictional statute, adopted by Congress and signed by President Washington in 1789 , provided that the Supreme Court's review jurisdiction extended to any

final judgment or decree in any suit, in the highest court of law or equity of a State ... where is drawn in question the construction of any clause ... of a treaty ... and the decision is against the title, right, privilege or exemption specially set up or claimed by either party, under such clause of the said ... treaty....

The Judiciary Act of 1789 , ch. $20, \S 25,1$ Stat. 73, 85-86 (1789) (current version at 28 U.S.C. $\$ 1257$ (a) (2000)).

333 The statutes on the Supreme Court's certiorari jurisdiction for cases decided by the supreme courts of the states, the District of Columbia, and Puerto Rico, still make reference to the application of treaty law. See 28 U.S.C. $\$ 1257$ (a) (providing that such review jurisdiction extends to cases

where the validity of a treaty ... of the United States is drawn in question or where the validity of a statute of any State is drawn in question on the ground of its being repugnant to . . . treaties ... of the United States, or 


\section{The Constitutional Nature of Treaties}

It is nonetheless critical here to understand the unique nature of the treaty power in our constitutional design. Statutes and treaties may find the same constitutional source for their status as federal law, ${ }^{334}$ but the power to promulgate Article I laws and the power to make treaties proceed from different constitutional sources of authority. Article I, Section 8, provides that Congress "shall have the Power" to exercise legislative authority over a broad array of subjects. ${ }^{335}$ But in a near exact textual parallel, Article II, Section 2, provides that the President separately "shall have Power" to make treaties, provided a super-majority of the Senate concurs. ${ }^{336}$

The constitutional message of this structural distinction, as David Golove has explained, is that the treaty power represents a separate and independent delegated power to create federal law. ${ }^{337}$ To state the proposition differently, the treaty power is not merely another vehicle for exercising the specific legislative powers granted to Congress in Article I. ${ }^{338}$ Rather, "treaties are alternative modes of promulgating laws." 339

This premise animated the Supreme Court's foundational pronouncement on the treaty power in Missouri $v$. Holland. ${ }^{340}$ As a delegated power in its own right, the treaty power overcomes the general federalism limitation-most prominently expressed in the Tenth Amendment ${ }^{341}$ - that all powers not delegated to the federal govern-

where any title right, privilege, or immunity is specially set up or claimed

under ... the treaties ... of ... the United States

); id. $\$ 1257$ (b) (including the District of Columhia in the definition of a "State" for such purposes); $i d$. $\$ 1258$ (extending similar jurisdiction for final judgments or decrees by the Supreme Court of the Commonwealth of Puerto Rico).

334 See U.S. Const. art. VI, cl. 2.

335 See $i d$. art. $1, \S 8$ (stating that Congress "shall have the Power" to collect taxes, borrow money, and regulate interstate commerce, among other actions).

336 See supra note 47 and accompanying text.

337 See Golove, supra note 10, at 1284 (arguing that the treaty power is an independent delegated power, not merely a "secondary mode for exercising the legislative powers delegated to Congress").

338 See id. at 1284.

339 See id. at 1286 n.717.

340252 U.S. 416 (1920).

341 U.S. Const. amend. X (providing that " $[\mathrm{t}]$ he powers not delegated to the United States by the Constitution, nor prohibited by it to the States, are reserved to the States respectively, or to the people"). Indeed, as the Supreme Court likewise concluded in Missouri $v$. Holland, even a non-self-executing treaty may establish the constitutional authority for Article I legislation beyond the limits of the interstate commerce clause, based on the authority granted by the Necessary and Proper Clause. See 252 U.S. at 431-32; see also U.S. Const. art. I, $\$ 8$, cl. 18 (granting to Congress the power to "make all Laws which shall be necessary and proper for carrying in to Execution the foregoing Powers, and all other Powers vested by this Constitution in the Government of the United States, or in any Department or Officer thereof"). 
ment are reserved to the states. ${ }^{342}$ Thus, although-like many other aspects of treaty law in recent years ${ }^{343}$ - this proposition is not without controversy, ${ }^{344}$ the substantive scope of the treaty power is not subject to the specific federalism limits imposed on Congress's Article I legislative powers. ${ }^{345}$ Because it provides lawmaking authority independent of that delegated in Article I, the treaty power likewise is not subject to the specific separation of powers principle that "[a]ll legislative Powers" described in Article I are vested in Congress as a whole. ${ }^{346}$

This division of the legislative power of Article I and the lawmaking power of Article II reflects an important insight of the Framers. Quite apart from its impact as domestic law, a treaty may accomplish a legal act that statutes, by their nature, may not: it may create an international obligation of the United States as part of a reciprocal obligation of a foreign sovereign. ${ }^{347}$ In the process, a treaty may secure foreign rights and benefits for the United States (and, significantly, its individual citizens) that often will be beyond the legislative powers of United States acting alone. ${ }^{348}$ The price for this benefit, of course, is

342 See Missouri $v$. Holland, 252 U.S. at 432 (observing that in ascertaining the scope of the treaty power "it is not enough to refer to the Tenth Amendment, reserving the powers not delegated to the United States, because by Article II, Section 2, the power to make treaties is delegated expressly"); see also Golove, supra note 10, at 1286 (arguing that "whenever a treaty makes a stipulation on a subject falling within the exclusive legislative competence of the states, the 'federalism' subject matter restrictions which would apply to acts of Congress are not applicable," but noting that this does not necessarily override other manifestations of the federalism principle).

343 See, e.g., supra notes 12-19 and accompanying text (describing the extant controversies over the scope of the treaty power).

344 See Bradley, Treaty Power, supra note I3, at 45 I-61 (arguing that federalism interests and the enumerated powers doctrine require substantive limits on the scope of the treaty power); Bradley, Treaty Power II, supra note 13, at 111-18 (arguing that criticisms of his position overlook the force of recent Supreme Court federalism decisions).

345 In recent years, the Supreme Court has famously reanimated the limits of the Commerce Clause. See, e.g., United States v. Morrison, 529 U.S. 598, 617-18 (2000) (ruling that Congress cannot regulate local, noneconomic activity on the sole basis that, in the aggregate, it has a substantial effect on interstate commerce); United States v. Lopez, 514 U.S. 549, 562 (1995) (concluding that congressional powers under the Commerce Clause do not extend to the regulation of activities having no "explicit connection with or effect on interstate commerce").

346 See U.S. Const. art. I, § 1 ("All legislative Powers herein granted shall be vested in a Congress of the United States, which shall consist of a Senate and House of Representatives."); see also Golove, supra note 10, at I286 (explaining that because the treaty power represents an independent mode for the creation of federal law, "whenever a treaty makes stipulations on subjects falling within the scope of Congress's legislative authorities, the treaty overrides the general separation of powers principle that legislative authority is vested in Congress").

347 As noted earlier, the precise substantive requirements for the conclusion of a constitutionally valid treaty are the subject of substantial scholarly debate. See supra notes 12-16 and accompanying text.

348 There is considerable controversy over whether the Constitution permits the ratification of a treaty through standard Article I legislation (so-called "congressional-executive agreements") and without compliance with the Article II, Section 2, Senate consent proce- 
the reciprocal international obligation assumed by the United States. ${ }^{349}$ It is this reciprocal international obligation that differentiates a self-executing treaty from standard Article I legislation. It is also precisely this aspect of a self-executing treaty that creates a significantly different context for understanding the relationship between the treaty power and other structural aspects of the Constitutionnotably federalism and separation of powers. ${ }^{350}$

This does not mean that an exercise of the treaty power is somehow detached from the express limitations of the Constitution. To the contrary, it is well-settled that treaties remain subject to constitutionally guaranteed individual rights, as the Supreme Court emphasized less than a year ago. ${ }^{351}$ Thus, a treaty may not, for instance, abridge the freedoms of speech and press as protected in the Constitution. ${ }^{352}$ More generally, a treaty may not contravene affirmative grants of rights to the states ${ }^{353}$ or otherwise compromise essential aspects of their sovereignty. ${ }^{354}$ For parallel reasons, treaty-lawmakers may not arrogate to themselves a power that is textually allocated to another constitutional institution. ${ }^{355}$ The limited power to appropri-

dure. See Ackerman \& Golove, supra note 12, at 820-32 (arguing that congressional-executive agreements have a long history of uncontroversial use in the United States); Tribe, supra note 12, at 1228-35 (suggesting that such alternative means of consent to treaties violate the Constitution).

349 See Golove, supra note 10, at 1093-95 (arguing that "[t]he national government enters into treaties in order to protect the rights of United States citizens abroad and to further our foreign policy interests more generally," and that the creation of reciprocal domestic law is the "price" for the acbievement of these aims).

350 See infra Part III.B.2 (analyzing the relationship of the treaty power with constitutional federalism limitations); infra Part III.B.3 (analyzing the relationship of the treaty power with the separation of powers doctrine).

351 See Am. Ins. Ass'n v. Garamendi, 123 S. Ct. 2374, 2387 n.9 (2003) (reaffirming that treaties are "[s]ubject . . . to the Constitution's guarantees of individual rights") (citing Boos v. Barry, 485 U.S. 312, 324 (1988); Reid v. Covert, 354 U.S. 1, 15-19 (1957)).

352 See U.S. Const, amend. 1. But cf. Boos, 485 U.S. at 324 (noting that it may be appropriate to apply a more flexible First Amendment analysis in the specific field of diplomacy, but expressly declining to opine on the issue).

353 An attempt by treaty, for instance, to change the geograpbic boundaries of a state, see U.S. ConsT. art. IV, $\S 3, \mathrm{cl} .1$, to abridge the right to a republican form of government in the states, see id. art. IV, $\S 4$, or to deny equal suffrage of the states in the Senate, see id. art. $\mathrm{V}$, would run afoul of the corresponding affirmative protections in the Constitution.

354 A strong argument can be made, for instance, that the structural and bistorical protections preventing the federal government from commandeering state institutions to implement federal policy also apply to exercises of federal power through treaties. $C f$. Printz v. United States, 521 U.S. 898, 932-33 (1997) (ruling that the federal government cannot commandeer state executive branch officials to conduct background checks for purchasers of handguns); New York v. United States, 505 U.S. 144, 161-66 (1992) (bolding that the Constitution probibits Congress from compelling state legislatures to fulfill regulatory programs at the federal level).

355 Alexander Hamilton provided an example of this proposition as early as 1796:

A treaty . . . cannot transfer the legislative power to the Executive Department nor the power of this last Department to the Judiciary; in otber words it can not stipulate tbat the President and not Congress shall make laws for 
ate federal funds provides a good example. ${ }^{356}$ These fundamental manifestations, respectively, of federalism protections and the separation of powers doctrine remain applicable to treaties as they do to statutory exercises of federal power.

\section{The Judicial Power and the Executive Power}

On the other hand, the difference between the constitutional sources of authority for statutes and treaties does not mean that the Constitution insulates treaties from the judicial power of Article III. Professor John Yoo has argued, for instance, that we can extract a hidden message from the mere placement of the Treaty Clause in Article II. ${ }^{357}$ In his view, this structural distinction transforms the treaty category of federal law into an "executive power" solely within the authority of the President. ${ }^{358}$ From this, and the respective vesting clauses of Article I and Article II, ${ }^{359}$ Professor Yoo concludes that the President has the "unilateral freedom" 360 to interpret and apply

the U[nitedl States; that the Judges and not the President shall command the national forces \&cc.

Alexander Hamilton, The Defence No. XXXVI (Jan. 2, 1796), reprinted in 20 The Papers of Alexander Hamilton 3, 6-7 (Harold C. Syrett ed., 1974); see also Golove, supra note 10, at 1083-84 \& $\mathrm{n} .21$ (providing Hamilton's quotation and describing the related separation of power limitations on the treaty power in more detail). Hamilton's observation does not reflect, however, an absolute and inflexible constitutional precept. See supra Part II.B.1 (discussing the accepted proposition that Congress may delegate to other federal institutions certain powers it could otherwise exercise itself); infra Part 1II.B (analyzing the same proposition in the treaty context).

356 See U.S. ConsT. art. I, \$9, cl. 7 (providing that "[n]o Money shall be drawn from the Treasury, but in Consequence of Appropriations made by Law"). For more detail on this point, see Golove, supra note 10 , at $1084 \& \mathrm{n} .23$, which provides historical support for this proposition.

357 See Yoo, supra note 18, at 869-70.

358 See id. at 870 (contending that the placement of the Treaty Clause in Article II "indicates that the power to make treaties, and by extension to interpret them, remains an executive one"); see also id. at 869 (arguing that "[a] textual examination of the Constitution indicates that the treaty power is fundamentally executive in nature”); $i d$. at 853-54 (arguing that "the framing generation likely understood the treaty power as an exclusively executive power, and hence that those who established our constitutional system believed the President should have the power to interpret treaties").

359 See U.S. Const. art. 1, \$ 1 (providing that "[a]ll legislative Powers herein granted" are vested in the Congress); id. art. II, $\S 1$, cl. 1 (providing that "[t]he executive Power" is vested in the president); see also Yoo, supra note 18, at 869-70 \& $\mathrm{n} .48$ (citing both of these provisions for support).

360 Yoo, supra note 18, at 868 (arguing that the President should have "unilateral freedom to interpret and reinterpret treaties"); id. at 878 ("[T] he President[ ] . . ought to control the interpretation of an international agreement."). Indeed, as the reference to "reinterpretation" in this passage makes clear, Professor Yoo even contends that each president has the authority to change the substantive meaning of a treaty over time. Thus, the very content of federal law in the form of a treaty would remain subject to the flexible (even situation-specific) desires of executive branch officials. 
treaties as federal law, ${ }^{361}$ even to the exclusion of the Supreme Court. ${ }^{362}$

Such a hyper-structuralist reading of the treaty power is misguided on a number of levels. First, as I have explained in more detail elsewhere, ${ }^{363}$ the suggestion that the President has the exclusive authority to interpret treaties disregards the express description of the "judicial Power" in Article III of the Constitution. In language that is parallel to Article II's Vesting Clause, ${ }^{364}$ Article III, Section 1, provides that " $t]$ he judicial Power of the United States, shall be vested" in the federal courts. ${ }^{365}$ The following section, as should now be clear, provides that this judicial power extends to treaties as well. ${ }^{366}$

Second, the mere fact that the treaty power is situated in Article II does not mean that this judicial power is somehow transferred to the Executive, any more than Congress would have the exclusive power to interpret statutes merely because the authority to create this form of federal law appears in Article I. ${ }^{367}$ Nor, more generally, are powers expressly allocated to other constitutional institutions somehow reassigned to executive control merely because they affect foreign affairs. ${ }^{368}$

To be sure, the treaty power does not fit neatly into either the legislative or the executive powers. Indeed, where international obli-

361 See id. at 869 ("In order to give every word in the Constitution meaning, we should construe th [e] 'herein granted' Ianguage as limiting Congress's legislative powers to the list enumerated in Article 1, Section 8, while Article II's Vesting Clause must refer to inherent executive and judicial powers unenumerated elsewhere in the document."). Likewise, in Professor Yoo's view, the mandatory involvement of the Senate in the creation of federal law through a treaty merely suggests that, in this rare instance, it is permitted to participate in the exercise of an executive power. See id. ("[T]he Senate's participation in treaty making and appointments merely indicates the dilution of the unitary nature of the executive branch, rather than the transformation of these functions into legislative powers."); see also id. at 870 ("The Senate's advice and consent power does not transform the treaty power into a legislative function; instead, it makes the Senate part of the executive hranch for purposes of making international agreements.").

362 See Yoo, supra note 19, at I322-28.

363 See Van Alstine, supra note 19, at I275-80 (responding to the argument that because the treaty power is located in Article II, the interpretation of treaties falls within the exclusive authority of the executive branch).

364 See U.S. Const. art. II, § 1, cl. 1.

365 See id. art. III, $\S 1$ (providing that the judicial power "shall be vested in one supreme Court, and in such inferior Courts as the Congress may from time to time ordain and establish").

366 See id. art. III, $\$ 2$, cl. 1 ("The judicial Power shall extend to ... Treaties made, or which shall be made under [the authority of the United States].").

367 See supra note 329 and accompanying text (noting established Supreme Court precedent that the interpretive views of a later Congress have "very little, if any, significance" (quoting Rainwater v. United States, 356 U.S. 590, 593 (1958))).

368 See Baker v. Carr, 369 U.S. 186, 2 II (1962) ("[I]t is error to suppose that every case or controversy which touches foreign relations lies beyond judicial cognizance."); see also infra note 572 and accompanying text (citing additional authority for the proposition that foreign affairs concerns alone do not remove a matter from the judicial power). 
gation is combined with domestic law self-execution, treaties partake of both constitutional powers. ${ }^{369}$ And an attempt by the judiciary to bind the executive branch with regard to the force of treaties that are not self-executing (like many addressing arms control and defense) may raise serious separation of powers concerns. ${ }^{370}$ But the inclusion of treaties in both the Supremacy Clause of Article VI and the judicial power of Article III makes clear that, where their substance so directs, the constitutional product of treaties is fundamentally the same as Article I legislation: judicially enforceable supreme federal law.

Finally, although treaties come into being through a constitutional process that the President formally initiates, Article II also requires the consent of a legislative institution, the Senate, before treaties acquire the force of domestic law. ${ }^{371}$ To suggest that the President has exclusive authority to reinterpret the force of self-executing treaties would render irrelevant the Senate's mandatory participation in the creation of Article II treaty law. ${ }^{372}$ It is in light of these considerations that the Supreme Court has continually confirmed that the determination of individual rights under a self-executing treaty is fundamentally a judicial, rather than executive, responsibility. ${ }^{373}$

In sum, the relationship of the Article III judicial power with selfexecuting treaties under Article II proceeds from a constitutional source of authority that is at least as powerful as that for Article I laws. With this foundation, this Article now turns to an analysis of whether, like its statutory counterpart, a self-executing treaty may properly serve as a vehicle for an express delegation of lawmaking powers to federal courts.

369 For a thoughtful historical analysis of the nature of treaties concluded under the Constitution, see Rakove, supra note 106, at 236-67 (examining the debates over the treaty power in the constitutional convention, in the ratification debates, and among other contemporary authorities); see also Flaherty, supra note 15, at 2105-12 (analyzing pre-Constitution thought on the nature of the treaty power); id. at 2137-38 (discussing Alexander Hamilton's belief that although the treaty-making power is neither solely executive nor solely legislative in nature, if one applies a more rigid view it "will be found to partake more of the legislative than of the executive character" (quoting THE FEDERALIST No. 75, at 450 (Alexander Hamilton) (Clinton Rossiter ed., 1961))).

370 Particularly, in this respect, Professor Yoo mistakenly conflates the separation of powers concerns related to self-executing treaties with those that would arise from judicial interpretation of treaties which do not operate as domestic law under the Supremacy Clause. See Yoo, supra note 19, at 1315-28 (arguing that the separation of powers and political question doctrines preclude federal courts from interpreting any treaties as federal law).

371 See U.S. Const. art. II, § 2, cl. 2.

372 See Van Alstine, supra note 19, at 1275-78 (critiquing this argument in greater detail).

373 See supra notes 325-28 and accompanying text (citing and analyzing Supreme Court and other federal court precedent on this point); see also Van Alstine, supra note 19, at 1287-89 (analyzing this point in more detail). 
B. The Constitutionality of an Express Delegation of Lawmaking Powers Through Treaties

\section{Background}

One might properly conceive of a treaty as the quintessential means by which a nation formally conducts its foreign relations. In the United States, it is now established jurisprudence that matters of foreign affairs also represent a constitutionally sanctioned field of federal common law. ${ }^{374}$ 1t is tempting to assume from this foundation that federal courts are always vested with lawmaking powers over any subject matter addressed by a treaty.

This simple syllogism overlooks, however, the important distinction between the existence of a power and the exercise of that power. Some core issues of the nation's foreign relations by their very nature are exclusively federal. ${ }^{375}$ Even without guidance from express forms of positive federal law, therefore, federal courts have the constitutional responsibility to resolve such matters through federal law rules of their own making. At the risk of stating the obvious, however, not all issues with peripheral effects on foreign affairs are of this nature. ${ }^{376}$

Where, in contrast, a treaty is the assumed foundation for an authorization of federal court lawmaking, that foundation has only a bounded federal law footprint. To be more succinct, the treatylawmakers have a constitutional power to create federal law, but their exercise of that power in any given case has its limits. It is within these limits that a self-executing treaty both elevates a particular subject matter to federal law and includes it within the international obligations of the United States.

This point is all the more important as treaty law continues to expand from conventional matters of arms control and peaceful relations into subjects traditionally left to domestic legislation. ${ }^{377}$ For instance, the mere existence of a self-executing treaty on international

374 See supra notes 286-90 and accompanying text (analyzing the foreign affairs enclave of federal common law).

375 See supra notes 284-90 and accompanying text.

376 The Supreme Court has never suggested that federal law preempts all state laws with tangential implications for foreign affairs, to say nothing of the authority of federal courts to create federal common law on the subject. See, e.g., Japan Line, Ltd. v. County of Los Angeles, 441 U.S. 434, $456 \mathrm{n.20}$ (1979) (noting that federal law did not preempt state law when "risk that foreign commerce would be burdened by inconsistent international regulation was 'remote'" (citing Bob-Lo Excursion Co. v. Michigan, 333 U.S. 28, 37 (1948))); Zschernig v. Miller, 389 U.S. 429, 458 (1968) (Harlan, J., concurring) (observing that federal law does not preempt state law merely because the state law might have "some incidental or indirect effect' " on foreign commerce (quoting Clark v. Allen, 331 U.S. 503, $517(1947))$ ).

377 See discussion supra Part 1.C (describing the expansion of self-executing treaties into numerous traditional domestic law subjects). 
child abduction ${ }^{378}$ does not (without more) transform all related state law parental rights-or for that matter, prior federal law rights ${ }^{379}$ into matters of federal treaty law. ${ }^{380}$ The nature of such a treaty may require that federal courts exercise interstitial lawmaking powers in order to uphold the broad constitutional grant to the federal government of authority over foreign affairs. ${ }^{381}$ But one cannot extract this conclusion from the mere fact that the Constitution delegates exclusive control over treaty-making to the federal government.

This is merely another way of saying that even for the law within the scope of treaties, the judiciary requires an identifiable source of authority for any valid exercis $\epsilon$ of lawmaking powers. ${ }^{382}$ For matters of uniquely federal concern, that source is the Constitution. Beyond this field, however, the lawmaking powers of federal courts must derive from a mandate by those constitutional institutions empowered to create federal law on their own (for statutes, the legislature, in interaction with the executive; for treaties, the reverse).

Recall that for Article I legislation, an express congressional delegation does not contravene constitutional limitations on federal judicial lawmaking. ${ }^{383}$ Section 2 below will demonstrate that the

378 See Convention on International Child Abduction, supra note 189; see also 42 U.S.C. $\$ 11601$ (a) (4) (2000) (setting forth a congressional finding that the convention "establishes legal rights ... for the prompt return of children who have been wrongfully removed or retained, as well as for securing the exercise of visitation rights"). For recent applications of this convention, see Delvoye v. Lee, 329 F.3d 330, 334 (3d Cir. 2003), which upheld the custody rights of a mother under the convention in the face of claims by a father seeking the return of a child to Belgium, and Antunez-Fernandes v. Connors-Fernandes, 259 F. Supp. 2d 800, 810-11 (N.D. Iowa 2003), which upheld the rights of a father under the convention after his children were removed from France to the United States.

379 As explained above, under the "later-in-time rule," a treaty may displace even earlier federal statutes to the extent that any conflict exists between the two. See supra notes 165-66 and accompanying text (analyzing this rule); see also Breard v. Greene, 523 U.S. 371, 376 (1998) (observing that "when a statute which is subsequent in time is inconsistent with a treaty, the statute to the extent of conflict renders the treaty null' (quoting Reid v. Covert, 354 U.S. 1, 18 (1957))); Whitney v. Robertson, 124 U.S. 190, 194 (1888) (stating that, when an act of legislation conflicts with the selfexecuting provisions of a treaty, "the one last in date will control the other").

380 See, e.g., Egervary v. Young, 159 F. Supp. 2d 132, 138 (E.D. Pa. 2001) (applying the International Child Abduction convention, but noting that courts may rely on other " "[f] ederal or [s] tate law, as appropriate, to protect the well-being of the child involved or to prevent the child's further removal or concealment before the final disposition of the petition" (quoting 42 U.S.C. $\$ 11604(\mathrm{a})$ )).

381 See supra Part I.A.1 (examining the notion that the Constitution vests exclusive authority over foreign affairs in federal institutions); see also U.S. Const. art. I1, $\$ 2$, cl. 2 (conferring treaty-making power on the President); id. art. I, $\$ 10, \mathrm{cl} .1$ (prohibiting states from entering into any "Treaty, Alliance, or Confederation").

382 See supra notes 218-23 and accompanying text (discussing the principle that because federal courts do not have independent lawmaking powers, they must have some independent source of authority to make federal common law).

383 See supra notes 236-52 and accompanying text (describing Supreme Court approval of congressional delegations of lawmaking authority to the federal courts). 
arguments in favor of this proposition are at least as powerful in the context of a delegation by treaty. ${ }^{384}$ An express authorization of federal judicial lawmaking by treaty-lawmakers does not run afoul of federalism protections. ${ }^{385}$ For parallel reasons, such a delegation of circumscribed powers to the federal courts also remains faithful to the limits imposed by the separation of powers doctrine. ${ }^{386}$

\section{Vertical Allocations of Power: Express Treaty Delegation and Federalism}

The limitations on federal common law, forcefully articulated in Erie Railroad Co. v. Tompkins, ${ }^{387}$ are most powerfully justified in the structural constitutional protections of federalism. ${ }^{388}$ As a general proposition, these limitations on exercises of federal power apply to treaties $^{389}$ just as they do to other forms of federal lawmaking. ${ }^{390}$ An express delegation of lawmaking authority through the vehicle of a treaty, however, overcomes the federalism constraints on lawmaking by the federal courts.

An authorization of federal judicial lawmaking is itself an exercise of the treaty-lawmakers' power to displace state law with federal law rules. In the first instance, the treaty power represents the states' constitutional delegation of authority to create federal law, through the prescribed Article II process, to the President and a supermajority of

\footnotetext{
384 Thus far there has been only limited scholarly recognition of this issue. See Lovis Henkin, Foreign Affairs and the United States Constitution 470 n.83 (2d ed. 1996) (concluding that " $[\mathrm{i}] \mathrm{t}$ has heen assumed that constitutional limitations on delegation of legislative power apply as well to delegation by treaty"); Golove, supra note 10, at 1286 $\mathrm{n} .717$ (observing that because treaties "are alternative modes of promulgating laws" they "ought presumptively to be subject to the same restrictions on delegations to which the identical laws would be subject"); see also Field, supra note 29, at 889 (arguing that "the process and standards for making federal common law are the same when a treaty . . is the source of authority"). For analyses of treaty delegation to international institutions, see generally Curtis A. Bradley, International Delegations, the Structural Constitution, and Non-SelfExecution, 55 Stan. L. Rev. 1557 (2003); David Golove, The New Confederalism: Treaty Delegations of Legislative, Executive, and Judicial Authority, 55 STAN. L. REv. 1697 (2003); Julian G. $\mathrm{Ku}$, The Delegation of Federal Power to International Organizations: New Problems with Old Solutions, 85 MinN. L. Rev. 71 (2000).

385 See discussion infra Part 111.B.2.

386 See discussion infra Part 111.B.3.

387304 U.S. 64 (1938).

388 See supra notes 206-09 and accompanying text.

389 See Golove, supra note 10, at 1085-86 (observing that "treaties are not immune from federalism limitations, and nothing in Missouri [v. Holland] suggests the contrary," but arguing that a "differential treatment" may be appropriate for treaties (citing Missouri v. Holland, 252 U.S. 416 (1920)))); see also Bradley, Treaty Power, supra note 13, at 451-56 (proffering a broad defense of federalism limitations on the permitted subject matters of treaties).

390 As explained below, however, the particular nature of treaties creates a different context for examining the force of federalism and similar limitations on implied delegations of federal common law authority. See discussion infra Part IV.B-C.
} 
the Senate. ${ }^{391}$ Like any other treaty provision, an express delegation to the federal courts, in turn, reflects a determination by these treatylawmakers that a particular rule of decision should have a federal, not state, source. Although treaty-lawmakers ultimately confer discretion on a coordinate branch of the federal government-here, the judiciary-the initial decision for federalism purposes is made by those federal institutions with the constitutional authority to make such judgments.

With such a foundation, federal court lawmaking within the scope of a treaty does not represent " 'an unconstitutional assumption of powers by the [C] ourts of the United States." "392 In other words, the creation of federal law does not flow from the federal courts' arrogation of power, but rather from a decision in the first instance by the President and the Senate to displace state law through the treaty power. Express delegation by the treaty-lawmakers, in short, represents an identifiable source of authority for federal court lawmaking. ${ }^{393}$

Nor does the Rules of Decision Act represent an independent concern. Recall that apart from formal rules "require[d]" by federal law, the Act also permits federal courts to apply a federal rule of decision when a statute or treaty so "provide[s]." 394 Properly understood, a treaty may provide a means for the creation of a federal rule of decision, including through a delegation of decision-making authority to another federal institution. ${ }^{395}$ As such, when a treaty expressly delegates federal judicial lawmaking powers, in accordance with constitutionally prescribed procedures, it surmounts the Rules of Decision Act hurdle. ${ }^{396}$

Indeed, compelling arguments support the conclusion that federalism concerns over federal court lawmaking are less convincing in

391 See supra notes $337-46$ and accompanying text.

392 Erie, 304 U.S. at 79 (quoting Black \& White Taxicab \& Transfer Co. v. Brown \& Yellow Taxicab \& Transfer Co., 276 U.S. 518, 533 (1928) (Holmes, J., dissenting)).

393 See supra notes 218-23 and accompanying text (finding support for the proposition that the federal courts must trace common-law powers to an identifiable source of authority).

39428 U.S.C. $\$ 1652$ (2000); see also supra notes 214-15 and accompanying text (discussing the role of the Rules of Decision Act for purposes of federal common law).

395 See Redish, supra note 29 , at 790 (noting that "the terms of the Rules of Decision Act do not require that the particular cases actually involve statutory interpretation" and concluding that the Act creates an exception where Congress provided for "federal judicial power to create common law"); see also Merrill, supra note 29, at 31-32 (observing that "[t]he phrase 'require or provide' is broad enough to embrace at least some interpretation of federal texts, and thus to support the creation of some federal common law," but emphasizing the limits on this notion).

396 As discussed below, the Rules of Decision Act also plays a significant role in allaying separation of powers concerns about delegating lawmaking powers through a treaty. See infra text accompanying notes 429-30. 
the treaty context. First, in contrast to most areas of Article I legislation, the Constitution deIegates the entire power to make treaties to the federal government and expressly prohibits such power to the states. ${ }^{397}$ Moreover, and again in contrast to federal statutes, the power to create federal law through treaties is plenary in substantive terms, as Missouri $v$. Holland ${ }^{398}$ definitively declared. ${ }^{399}$ Thus, the Erie Court's concern about federal courts circumventing the substantive limits on federal statutory powers ${ }^{400}$ is simply not relevant to the law within the scope of self-executing treaties.

Of equal importance, the Constitution provides greater procedural federalism protections for treaties than for Article I legislation. Before a treaty can become preemptive federal law, it requires the consent of two-thirds of the Senators present. ${ }^{401}$ The Framers carefully chose both this threshold and this institution for federal lawmaking through treaties. As the basic right of equal representation reflects, the Framers designed the Senate specifically to defend the interests of the states in the national legislature. ${ }^{402}$ The Framers intended this design, combined with a minority veto power for treaties, to prevent the federal government from using treaties to create federal law in the absence of sufficiently overriding national benefits. ${ }^{403}$ Substantially more than with statutes, therefore, the Constitution in-

397 See U.S. ConsT. art. I, $\S 10$, cl. 1 (providing that "[n]o State shall enter into any Treaty, Alliance, or Confederation"); see also Golove, supra note 10, at 1082 (concluding with reference to Article I, Clause 1, that "[i]t is clear . . . that the whole treaty power is 'delegated' to the federal government and specifically 'prohibited' to the states").

398252 U.S. 416 (1920).

399 As noted above, this proposition has become increasingly controversial in recent years. See supra note 13 and accompanying text (examining the scholarly controversy over whether there are any substantive limits on the scope of the treaty power). Nonetheless, whatever the merits of the respective positions, the Supreme Court has shown no inclination at all to reexamine its holding in Missouri $v$. Holland.

400 See Erie R.R. Co. v. Tompkins, 304 U.S. 64, 78 (1938) ("Congress has no power to declare substantive rules of common law applicable in a state whether they be local in their nature or 'general,' ... . [a]nd no clause in the Constitution purports to confer such a power upon the federal courts.").

401 See supra note 47 and accompanying text.

402 See Eugene W. Hickok, Jr., The Framers' Understanding of Constitutional Deliberation in Congress, 21 GA. L. Rev. 217, 256-57 (I986); Ralph A. Rossum, The Irony of Constitutional Democracy: Federalism, the Supreme Court, and the Seventeenth Amendment, 36 SAN Diego L. Rev. 671, 674-80 (1999).

403 See Golove, supra note 10, at 1098-99 (arguing that hecause the states are equally represented in the Senate and hecause of the requirement of a two-thirds vote for the approval of a treaty, "the Senate, fortified by a minority veto, was charged with the special political task of refusing its consent to any treaty that trenched too far on the interests of the states without serving a sufficiently powerful countervailing national interest"); $i d$. at 1272 ("The Framers . . . created a system designed to ensure rigorous scrutiny of treaties that threatened to undermine state interests ...."). 
corporates political process impediments to treaty making as a principal means to protect state interests. ${ }^{404}$

In short, although federalism concerns over federal court lawmaking do not disappear entirely, they diminish considerably when treaties, rather than statutes, create federal law. Where the treatylawmakers overcome the substantial procedural and political barriers to lawmaking through treaties, therefore, the case for the constitutionality of an express delegation of federal judicial lawmaking powers is even more compelling than in the statutory context.

Indeed, one comprehensive self-executing treaty already incorporates such an express delegation of developmental powers for federal courts. The United Nations Convention on Contracts for the International Sale of Goods ${ }^{405}$ - a treaty that broadly displaces the state law Uniform Commercial Code in the context of international sales transactions $^{406}$ - contains an express instruction for courts confronted with gaps in the convention's regulatory scheme. Article 7(2) empowers courts in such situations to construct a rule of decision "in conformity with the general principles on which [the Convention] is based." ${ }^{407}$ Neither the treaty itself nor its drafting history identify these "general principles," 408 however, nor are the courts tied to any specific intent of the drafters in exercising their gap-filling powers under this scheme.409 Thus, like the statutory delegations analyzed

404 Recent Supreme Court precedent in the statutory context has rejected the notion that the political process alone protects states' federalism interests. See United States v. Morrison, 529 U.S. 598, 647 (2000) (Souter, J., dissenting) (arguing that a defect in the majority's opinion is the "rejection of the Founders' considered judgment that politics, not judicial review, should mediate between state and national interests"); United States v. Lopez, 514 U.S. 549, 577-79 (1995) (Kennedy, J., concurring) (noting that "one conclusion that could be drawn from The Federalist Papers is that the balance between national and state power is entrusted in its entirety to the political process," but stating that The Federalist Papers also comprehend a narrow sphere of federal influence in state power and that "it would be mistaken and mischievous for the political branches to forget that the sworn obligation to preserve and protect the Constitution in maintaining the federal balance is their own in the first and primary instance"). As discussed below, however, there is an important distinction between treaties and statutes in this regard. See infra notes 530-31 and accompanying text.

405 CISG, supra note 173.

406 For a review of the general sphere of application of the UN Sales Convention, see Michael P. Van Alstine, Consensus, Dissensus, and Contractual Obligation Through the Prism of Uniform International Sales Law, 37 VA. J. INT'L L. 1, 9-13 (1996).

407 CISG, supra note 173, art. 7(2), 1489 U.N.T.S. at 61 . This provision permits resort to otherwise applicable domestic law only if a court cannot discern any general principles relevant to the specific issue in dispute.

408 See Van Alstine, supra note 25, at 761-91.

409 See id. at 775-78. This essential fact illustrates that the Convention does not merely grant enhanced interpretive powers to federal courts. Because it is not tied to any specific intent of the drafters, the courts' power to construct a rule of decision for gaps in the treaty is delegated lawmaking and not mere interpretation. See Clark, supra note 2, at 1248 ("By hypothesis, at least, federal common lawmaking begins where interpretation ends."); Field, 
above, ${ }^{410}$ by endorsing this gap-filling methodology the treatylawmakers gave "the courts the power to develop substantive law" 411 within the scope of this treaty. Significantly, this delegation approach has since become the paradigm for a whole class of other private law treaties. ${ }^{412}$

Finally, there is little doubt that an express delegation through a treaty requires uniform federal common law. In the statutory context, the Supreme Court on occasion has found it appropriate to round out a federal regulatory scheme by "borrowing" kindred rules of state law. 413 This line of authority is clearly inappropriate for gaps in treaties. As discussed in greater detail below, $414 \mathrm{a}$ basic principle of international law broadly precludes recognition of the law of municipal subunits in defining a nation's treaty obligations. ${ }^{415}$ U.S. domestic law

supra note 29, at 890 (defining federal common law as "any rule of federal law created by a court . . . when the substance of that rule is not clearly suggested by federal enactments").

410 See supra notes 242-57 and accompanying text (citing the express statutory delegation in Rule 501 of the Federal Rules of Evidence and the implied delegations in the Sherman Antitrust Act, Section 301(a) of the Labor Management Relations Act, and other legislative enactments).

411 Tex. Indus., Inc. v. Radcliff Materials, lnc., 451 U.S. 630, 640 (1981); see also Arthur Rosett, Critical Reflections on the United Nations Convention on Contracts for the International Sale of Goods, 45 OHIO ST. L.J. 265, 299 (1984) (observing that Article 7(2) of the UN Sales Convention "seems to express the wish that the broad terms of the Convention be filled in over time by a world common law, a shared body of interpretation that would supply a gloss on the text," but suggesting that the Convention fails to provide sufficient guidance on this score).

412 See, e.g., United Nations Convention on the Assignment of Receivables in International Trade, supra note 179, art. 8(2), 41 I.L.M. at 782; United Nations Convention on Independent Guarantees and Stand-by Letters of Credit, supra note 179, art. 13(2), 35 I.L.M. at 746; UNIDROIT Convention on International Factoring, supra note 179, art. 4(2), 27 I.L.M. at 945-46; Convention on International Financial Leasing, supra note 179, art. 6(2), 27 1.L.M. at 934; Convention on Agency in the International Sale of Goods, supra note 179 , art. $6(2), 22$ I.L.M. at 251.

413 See, e.g., Kamen v. Kemper Fin. Servs., Inc., 500 U.S. 90, 97-98 (1991) (observing that, in the absence of a distinct need for national uniformity or an analogous rule from a related statute, "federal courts should 'incorporat[e] [state law] as the federal rule of decision,' unless 'application of [the particular] state law [in question] would frustrate specific objectives of the federal programs'" (alterations in original) (quoting United States v. Kimbell Foods, Inc., 440 U.S. 715, 728 (1979))); see also Paul Lund, The Decline of Federal Common Law, 76 B.U. L. REV. 895, 968-98 (1996) (discussing cases in which federal courts have referred to state common law to resolve federal law questions); $c f$. Burlington Indus., Inc. v. Ellerth, 524 U.S. 742, 754-55 (1998) (holding that "Congress has directed federal courts to interpret Title VII based on agency principles," but stating that " $[t]$ his is not federal common law in 'the strictest sense, i.e., a rule of decision that amounts, not simply to an interpretation of a federal statute ..., but, rather, to the judicial 'creation' of a special federal rule of decision'" (quoting Atherton v. Fed. Deposit Ins. Corp., 519 U.S. 213, 218 (1997))). 414 See infra notes 492-96 and accompanying text.

415 See Restatement of Foreign ReLATions, supra note $75, \S 311 \mathrm{cmt}$ a (observing with regard to international agreements that "[a] State of the United States or a subdivision of another state is not a state having capacity to conclude an international agreement"); $c f$. Vienna Convention on Treaties, supra note 76, art. 27, 1155 U.N.T.S. at 339 ("A party may not invoke the provisions of its internal law as justification for its failure to perform a 
adopts essentially the same approach, ${ }^{416}$ for Article 1, Section 10, of the Constitution prohibits state lawmaking institutions from creating international treaty obligations. ${ }^{417}$ Consequently, when empowered to do so, courts must fill in the gaps of self-executing treaties without reference to the law of any particular state. ${ }^{418}$

\section{Horizontal Allocations of Power: Express Treaty Delegation and the Separation of Powers Doctrine}

Arguments against including federal common law within the scope of treaties extend beyond federalism. Because it reflects an initial determination by the President and the Senate to displace state law, an express delegation of common law powers would resolve federalism concerns. ${ }^{419}$ The separation of powers doctrine, however, represents a separate set of constraints on the federal courts' exercise of lawmaking powers.

\section{a. Potential Conflicts with Congress's Legislative Power}

"[I]t has always been accepted," as David Golove has observed, "that treaties are limited by separation of powers principles." 420 In the context of a delegation of developmental powers to federal courts, separation of powers concerns essentially distill into two categories. The first emanates from a potential conflict with Congress's legislative power under Article I. The second, analyzed separately in Part 111.B.3.b below, is based on the non-delegation doctrine and its extension to the Article II treaty context.

treaty."). Only an express reservation to a treaty can overcome this preclusion. For an examination of the import of the absence of such a reservation for purposes of the preemption of state law, see infra notes 530-31 and accompanying text.

416 See Hines v. Davidowitz, 312 U.S. 52, 63 (1941) (“[T]he interest of the cities, counties and states, no less than the interest of the people of the whole nation, imperatively requires that federal power in the field affecting foreign relations be left entirely free from local interference."); United States v. Belmont, 301 U.S. 324, 331 (1937) (declaring that "in respect of our foreign relations generally, state lines disappear" and "[a]s to such purposes the State ... does not exist”); Chae Chan Ping v. United States (The Chinese Exclusion Case), 130 U.S. 581, 606 (1889) ("For local interests the several States of the Union exist, but for national purposes, embracing our relations with foreign nations, we are but one people, one nation, one power."); Restatement of Foreign Relations, supra note 75, $\$ 201 \mathrm{cmt}$. g (observing that "[a] State of the United States is not a state under international law since under the Constitution of the United States foreign relations are the exclusive responsibility of the Federal Government").

417 See U.S. Const. art. I, $\$ 10$, cl. 1 ("No State shall enter into any Treaty, Alliance, or Confederation .....); see also supra notes 53-72 and accompanying text (discussing this provision in its context with the federal government's broader powers over foreign affairs).

418 See infra notes 532-54 and accompanying text (analyzing the force of uniformity concerns as a justification for broader assumption of the displacement of state law by treaties).

419 See discussion supra Part II.B.1.

420 See Golove, supra note 10 , at 1083. 
Because the process of creating a treaty does not involve the most representative legislative body (the House of Representatives), a delegation of lawmaking powers through the vehicle of a treaty first raises concerns about encroaching on the legislative authority of Congress as a whole. ${ }^{421}$ These concerns quickly dissolve, however, upon a review of the fundamental nature of the treaty power. Through the doctrine of self-execution, Article II establishes an alternative process for creating federal law. ${ }^{422}$ This lawmaking power exists, as described above, ${ }^{423}$ independent of the lawmaking power in Article I, and thus notwithstanding the language in Section 1 that "[a]1l legislative Powers herein granted" are vested in Congress as a whole. ${ }^{424}$ Indeed, in contrast to the careful list of expressly delegated subject matters in that Article, the lawmaking power in Article $1 \mathrm{II}$ is plenary. ${ }^{425}$ As a result, the notion that Congress as a whole possesses "[a]ll legislative Powers" does not represent a separate impediment to delegating the independent powers that Article II grants to treaty-lawmakers. ${ }^{426}$

The Rules of Decision Act plays a significant, positive role here as well. When carefully considered, the Act directly addresses separation of powers concerns regarding the House of Representatives' lack of involvement in treaty delegations. As the previous section made clear, ${ }^{427}$ the Act authorizes federal courts to apply federal rules of decision when a statute or treaty so "provide[s]." 428 Because the Act represents standard federal legislation adopted in accordance with the Article I lawmaking procedure, this authorization is a product of Congress as a whole. Thus, when a treaty so "provide[s]" for the creation of federal rules of decision by federal courts, ${ }^{429}$ the Rules of Decision Act reflects the consent of the entire Congress (including, of course,

421 See U.S. Const. art. I, § 1. Recall also that Article I, Section 8, Clause 3, specifically grants legislative authority to Congress for regulation of "Commerce with foreign nations." $I d$. art. I, $\$ 8$, ch. 3; see also Yoo, supra note 19, at 1315-16 (advancing an argument against federal common law under treaties).

422 See supra notes 78-89 and accompanying text (analyzing the doctrine of self-executing treaties).

423 See supra notes $337-46$ and accompanying text.

424 See U.S. ConsT. art. I, \$ 1.

425 See supra notes 340-56 and accompanying text (advancing the point that the treaty power is plenary, subject only to specific textual rights and prohibitions in the Constitution).

426 See Golove, supra note 10, at 1286 (observing that the treaty power authorizes the President and Senate "to promulgate laws" and thus concluding that "whenever a treaty makes stipulations on subjects falling within the scope of Congress's legislative authorities, the treaty overrides the general separation of powers principle that legislative authority is vested in Congress").

427 See supra notes 381-83 and accompanying text.

428 See 28 U.S.C. \$ 1652 (2000).

429 See supra notes 394-96 and accompanying text (analyzing how the Rules of Decision Act permits the application of federal rules of decision, if adopted pursuant to a delegation of common law powers to federal courts). 
the House of Representatives) for the federal judiciary to apply those rules in the place of otherwise applicable state law.

\section{b. The Non-Delegation Doctrine}

The separation of powers concerns reflected in the non-delegation doctrine represent a more challenging problem. As in the statutory context, the issue here is the propriety of delegation from constitutionally recognized federal lawmakers to an institution (the federal judiciary) which fundamentally does not possess such a power.

Recall from the earlier analysis of the statutory context the general proposition that Congress may not delegate the entirety of its legislative powers on a given subject to either of its coordinate branches. ${ }^{430}$ Presumably, the Supreme Court's generalized observation that Article I "permits no delegation of [Congress's legislative] powers" 431 would apply as well to the treaty power; for the strict text of Article II also contains no formal indication that the treaty-lawmakers may delegate powers to other constitutional institutions. ${ }^{432}$ Bolstered by the related constitutional values of electoral accountability and adherence to prescribed lawmaking procedures, ${ }^{433}$ the question that arises here is whether the Constitution permits treaty-lawmakers to delegate developmental powers to federal courts.

The formal and functional arguments in favor of the constitutionality of a treaty delegation, however, are at least as compelling as those for the statutory form of federal law. In the latter context, the Supreme Court has long held that the Constitution permits Congress to delegate to the courts certain decision-making powers that it could otherwise exercise itself. ${ }^{434}$ In reasoning equally applicable to the treaty context, the Court has maintained that in light of the complexity of modern society, "Congress simply cannot do its job absent an ability to delegate power under broad general directives." 435 Some degree of policy-making discretion, moreover, is inherent in the judicial enterprise. ${ }^{436}$

430 See discussion supra Part II.B.1 (analyzing the non-delegation doctrine with regard to federal common law).

431 Whitman v. Am. Trucking Ass'ns, 531 U.S. 457, 472 (2001) (citing Loving v. United States, 517 U.S. 748, 771 (1996))

432 See supra note 47 and accompanying text.

433 See supra notes 211-13 and accompanying text (noting the influence of these re-

lated principles on the analysis of the propriety of federal common law).

434 See supra notes 232-33 and accompanying text.

435 Mistretta v. United States, 488 U.S. 361,372 (1989).

496 See id. at 415 (Scalia, J., dissenting) (

Once it is conceded, as it must be, that no statute can be entirely precise, and that some judgments, even some judgments involving policy considerations, must be left to ... the judges applying [the law], the debate over unconstitutional delegation becomes a debate not over a point of principle but over a question of degree. 
More important, for some legal subject matters the public interest may be served best by permitting flexibility in, or gradual supplementation of, the law to permit adjustment to future developments. In the context of treaties, the Constitution vests decisions about the proper degree of flexibility in the law in the President and the Senate. For those treaties that adopt this approach, then, the very judgment that a flexible exercise of common law powers will best serve the nation's international interests reflects an important policy determination by the treaty-lawmakers. The important role of such open-ended notions as good faith ${ }^{437}$ estoppel, ${ }^{438}$ and waiver ${ }^{439}$ in the law of contracts serves as a good example. It is for these reasons that the Supreme Court traditionally - and properly - has given wide latitude to its coordinate branches of government in their delegation of policymaking discretion to administrative agencies and the judiciary. ${ }^{440}$

The treaty-lawmakers nonetheless may not delegate wholly unguided power over an entire subject matter. Just as in the statutory context, a treaty may not simply direct federal courts, for example, to create a new body of federal family law. ${ }^{441}$ Rather, separation of powers considerations will require that a treaty delegation reasonably mark the boundaries of the lawmaking authority that treaty-lawmakers confer on federal courts. ${ }^{442}$ Thus, in parallel with statutes, ${ }^{443}$ a delegation of lawmaking powers must, at a minimum, reasonably set the

) .

437 See Restatement (SeCOND) OF Contracts $\$ 205$ (1981) ("Every contract imposes upon each party a duty of good faith and fair dealing in its performance and its enforcement.").

438 See id. $\$ 90$ (defining promissory estoppel).

439 See UNIFORM COMMERCIAL CODE $\$ \S 2-208(3)$, 2-209 (1998) (discussing waiver and its use in the course of contract performance).

440 See Whitman v. Am. Trucking Ass'ns, 531 U.S. 457, 474 (2001) (observing that throughout its history the Court has overturned Congress's decision to delegate on only two occasions); Touby v. United States, 500 U.S. 160, 165 (1991) ("Congress does not violate the Constitution merely because it legislates in broad terms, leaving a certain degree of discretion to executive or judicial actors."); see also 1NS v. Chadha, 462 U.S. 919, 951 (1983) (holding that " $[\mathrm{w}]$ hen any Branch acts, it is presumptively exercising the power the Constitution has delegated to it").

44 See supra notes 259-60 and accompanying text (discussing unbridled delegation in the statutory context).

442 See Field, supra note 29, at 933 (articulating the argument with regard to federal common law that the constitutionally empowered lawmakers must also reasonably delineate the content of the law that federal courts are to apply); Merrill, supra note 29, at 41 (arguing that, in addition to an intent requirement, a constitutional delegation must circumscribe the permissible field of judicial lawmaking "with reasonable specificity").

443 See supra notes $232-35$ and accompanying text (discussing the requirement that statutory delegation lay down an "intelligible principle" to guide the exercise of delegated lawmaking authority); see also Am. Trucking Ass'ns, 531 U.S. at 472 ("[W] repeatedly have said that when Congress confers decisionmaking authority upon agencies Congress must 'lay down by legislative act an intelligible principle to which the person or body authorized to [act] is directed to conform." (second alteration in original) (quoting J.W. Hampton, Jr., \& Co. v. United States, 276 U.S. 394, 409 (1928))). 
outer guideposts for the exercise of the delegated discretion. This condition-which further secures faithfulness to federalism protections ${ }^{444}$-ensures that those whom the Constitution empowers to create federal law through the vehicle of a treaty must also make the core determinations on substantive contours, both of the treaty and of the discretion that the treaty delegates.

Consider as an illustration the developmental powers conferred by the UN Sales Convention discussed above. ${ }^{445}$ Express provisions of the Convention first mark out its overall substantive sphere of application. 446 The delegation in Article 7(2) also describes the boundaries within which courts may exercise their lawmaking discretion. ${ }^{447}$ It does so by expressly authorizing the courts to fill only those regulatory gaps within the outer scope of the treaty, and only as guided by the values reflected in its text, context, and drafting history. ${ }^{448}$

Indeed, separation of powers considerations in the context of treaties, far from being constraints, in fact weigh strongly in favor of federal courts carrying into effect such an expressly circumscribed delegation of authority. The Constitution formally entrusts the power to conduct foreign affairs through a treaty to the President and the Senate. ${ }^{449}$ In some cases-such as the UN Sales Convention ${ }^{450}$ - tbese treaty-lawmakers may determine that the interests of the United States and its citizens are best advanced by a flexible, casuistic development by the courts to accommodate technological and social advancements in the particular field of law. This flexibility may itself be part of the international obligation that the treaty embodies. ${ }^{451}$ Interestingly, then, the functional consideration that the President and a super-majority of the Senate are best situated to make policy determinations regarding our international treaty obligations is the very principle that

\footnotetext{
444 See supra notes $206-09$ and accompanying text.

445 See supra notes 405-12 and accompanying text.

446 See CISG, supra note 173, art. 1(1), 1489 U.N.T.S. at 60 (stating that the Convention applies only to transactions for the sale of goods that also satisfy certain internationality requirements); see also id. arts. 2, 4, 1489 U.N.T.S. at 60 (excluding certain classes of transactions and issues that otherwise would fall within the scope of the treaty).

447 See id. arts. $1-5,7(2), 1489$ U.N.T.S. at 60-61.

448 See id. art. 7(2), 1489 U.N.T.S. at 61 (providing that the authority to fill gaps only extends to matters "governed by this Convention").

449 See supra notes $47-49$ and accompanying text.

450 See supra notes 405-12 and accompanying text (analyzing the example of an express delegation provided by the UN Sales Convention).

451 Thus, although the substantive provisions of a private law treaty such as the UN Sales Convention do not impose continuing obligations on the United States in its formal international conduct as a sovereign entity, they reflect international obligations nonetheless. These obligations are fulfilled simply by federal courts giving effect to the substantive provisions of the treaty in private disputes-including the requirement that federal courts fill gaps in the treaty with reference to its unarticulated and unformed "general principles." See supra notes 405-11 and accompanying text (describing the general principles methodology).
} 
requires federal courts to exercise flexible lawmaking powers when directed to do so-or in the words of the Rules of Decision Act, when a treaty so "provide $[\mathrm{s}] . " 452$

The mere situation of the Treaty Clause in Article II does not change this conclusion. Like Article I legislation, the inclusion of treaties within the federal "judicial Power" means that the final authority over the application of treaty law falls to the federal courts. That the President has the initial authority (with, significantly, the Senate's consent ${ }^{453}$ ) to make treaties does not mean that the executive branch interests automatically preclude the judicial branch from fulfilling an express mandate of interpretive discretion, any more than Congress's primary authority over Article I lawmaking prohibits all delegations of such authority through that form of federal law. ${ }^{454}$ The preeminent role of the President in matters of foreign affairs, as we have seen, justifies some respect for the executive branch's interpretation of treaties. .55 But once a treaty has passed into federal law through the self-execution doctrine, the combined power of the Supremacy Clause and Article III means that its judicial enforcement proceeds from the same constitutional foundation as that for Article I legislation. ${ }^{456}$

\section{Conclusion: Express Delegation and Federal Court Lawmaking Under Treaties}

In parallel with statutes, ${ }^{457}$ an express and delimited delegation of developmental powers through a treaty does not contravene constitutional limits on federal court lawmaking. As an exercise of an independent power to displace state law, an express delegation by the treaty-lawmakers does not run afoul of federalism limits. If it also reasonably marks the boundaries for the judicial exercise of its lawmaking discretion, such a delegation likewise satisfies separation of powers

\footnotetext{
45228 U.S.C. $\$ 1652(2000)$.

453 See supra note 47 and accompanying text.

454 See discussion supra Part I1.B.1.

455 See supra note 330 and accompanying text; see also Bradley, supra note 317 , at 701-07 (suggesting with regard to treaties that courts should apply a form of the "Chevron Doctrine," which defers to executive branch agencies' interpretations of statutes whose administration is entrusted to them by Congress); Van Alstine, supra note 19, at 1298-1302 (arguing that courts should give only calibrated deference to the interpretive views of the executive branch, based on the degrees to which a matter affects foreign affairs and the continuing enforcement of the treaty is entrusted to executive branch agencies).

456 As the subject of a treaty moves closer to sensitive matters of international diplomacy, separation of powers concerns may counsel heightened caution before recognizing implied delegations of common law powers. See infra notes 573-82 and accompanying text.

457 See discussion supra Part II.B.1.
} 
concerns about judicial exercises of lawmaking powers vested by Article II in the President and the Senate.

Due respect for the policy judgments of the treaty-lawmakers in fact militates strongly in favor of enforcing a decision that a delegation of flexible developmental fowers best furthers the international interests of the United States. Indeed, precisely this kind of due respect animates the Supreme Court's declaration concerning statutory delegations, which applies with no less force in the treaty context, that it has "'almost never felt qualified to second-guess Congress regarding the permissible degree of policy judgment that can be left to those... applying the law." 458

\section{IV}

Presumptive Federal Law in an Age of Treaties

\section{A. Present State of Confusion}

Much of the controversy over the lawmaking powers of federal courts arises from the simple fact that, however carefully articulated, the formal content of federal law often suffers from substantial indeterminacy. Although the Constitution formally grants federal lawmaking power to Congress and the President, they frequently fail to provide sufficient guidance to the courts on the application of the law to actual disputes. ${ }^{459}$ This Article has shown that an express authorization of federal court lawmaking by these formal institutionswhether through statute ${ }^{460}$ or treaty ${ }^{461}$-fully conforms to the Constitution. The friction arises, however, in the more common case where the degree of authorized judicial discretion does not benefit from such clarity. In no area is this problem more acute than in the judicial interpretation and application of self-executing treaties.

The Supreme Court traditionally has managed the uncertainty over the scope of federal law by resorting to meta-rules of interpretation. ${ }^{462}$ The most familiar, and perhaps most potent, of these is the "presumption against preemption" of state law by federal statutes. In its standard formulation, this background rule of interpretation instructs courts to "start with the assumption" that congressional legislation does not displace state law in a field of traditional state responsibility "unless that was the clear and manifest purpose of Con-

\footnotetext{
458 Whitman v. Am. Trucking Ass'ns, 531 U.S. 457, 474-75 (2001) (quoting Mistretta v. United States, 488 U.S. 361, 416 (1989) (Scalia, J., dissenting)).

459 See supra notes 243-52 and accompanying text (providing examples of statutes that implicitly delegate authority to federal courts to apply the common law to give effect to the statutes).

460 See discussion supra Part 1I.B.1.

461 See discussion supra Part 1II.B.

462 See William N. Eskridge, JR. et al., Legislation and Statutory Interpretation 331-69 (2000) (discussing substantive canons of statutory interpretation).
} 
gress." 463 Such a presumption, the Court has reasoned, upholds "the historic primacy of state regulation of matters of health and safety." 464 The validity of this limited view of federal preemption, even in the purely domestic context, is far from evident. ${ }^{465}$ Nonetheless, the Court trots out the presumption with regularity 466 and recently declared that it applies both to whether Congress intended "any preemption at all" and to "the scope of its intended invalidation of state law." 467

Similar, though less explicit, expressions exist for the broader issue of the common law powers of federal courts under statutes. ${ }^{468}$ The reasoning, with reference to federalism concerns, is that in general Congress possesses only concurrent lawmaking authority with the states. When Congress legislates in a field of traditional state competence, therefore, courts should not assume an authorization of federal court lawmaking. Rather, in such cases Congress is presumed to act "'against the background of the total corpus juris of the states." "469

463 Rice v. Sante Fe Elevator Corp., 331 U.S. 218, 230 (1947).

464 Medtronic, Inc. v. Lohr, 518 U.S. 470,485 (1996); see also Jones v. Rath Packing Co., 430 U.S. 519, 525 (1977) (observing that the presumption against preemption "provides assurance that 'the federal-state balance' will not be disturbed unintentionally by Congress or unnecessarily by the courts" (quoting United States v. Bass, 404 U.S. 336, 349 (1971) (citation omitted))).

465 As Professor Viet Dinh has explained, "the constitutional structure of federalism does not admit to a general presumption against federal preemption of state law." Viet D. Dinh, Reassessing the Law of Preemption, 88 Geo. L.J. 2085, 2087 (2000). When Congress adopts legislation within the scope of its constitutionally delegated powers, he argues, the proper question is only one of statutory interpretation and not of "the vertical distribution of powers between federal and state governments." Id. at 2092. Indeed, "the logic of and the principles animating the Supremacy Clause would seem to suggest, if anything, a bias in favor of preemption, not against." Id. at 2094; see also Jack Goldsmith, Statutory Foreign Affairs Preemption, 2000 SUP. CT. REv. 175, 182-87 (criticizing the presumption against preemption on several grounds). But see Clark, supra note 211, at 1428-30 (disagreeing with Professor Dinh's argument regarding the presumption).

466 See, e.g., Pharm. Research \& Mfrs. of Am. v. Walsh, 123 S. Ct. 1855, 1869 (2003); Medtronic, 518 U.S. at 494; N.Y. State Conference of Blue Cross and Blue Shield Plans v. Travelers Ins. Co., 514 U.S. 645, 654-55 (1995); BFP v. Resolution Trust Corp., 511 U.S. 531, 544 (1994); Pac. Gas \& Elec. Co. v. State Energy Res. Conservation \& Dev. Comm'n, 461 U.S. 190, 206 (1983).

467 Medtronic, 518 U.S. at 485.

468 See Atherton v. Fed. Deposit Ins. Corp., 519 U.S. 213, 218 (1997) (observing that the mere existence of a related federal statute does not "automatically show that Congress intended courts to create federal common-law rules") (citing Wallis v. Pan Am. Petroleum Corp., 384 U.S. 63, 68 (1966))); see also BellSouth Telecomms., Inc. v. MCImetro Access Transmission Servs., 317 F.3d 1270, 1291 (1 Ith Cir. 2003) (embracing a "clear congressional intent" requirement for federal common law powers under statutes (citing ERwiN Chemerinsky, Federal Jurisdiction $\$ 6.3 .2$ (3d ed. 1999) (suggesting that the Supreme Court's holding in Texas Industries, Inc. v. Radcliff Materials, Inc., 451 U.S. 630, 647 (1981), reaffirms the principle that the "federal judiciary will formulate a body of common law rules only pursuant to clear congressional intent for such action"))).

469 Wallis, 384 U.S. at 68 (quoting H. Hart \& H. Wechsler, The Federal Courts and THE Federal SYSTEM 435 (1953)); see also Atherton, 519 U.S. at 218 (restating this quote with approval). 
Although these propositions may be well-settled for domestic legislation, the law for self-executing treaties, by a charitable description, suffers from significant incoherence. The Supreme Court at various times in its history-and without any apparent recognition of any conflict-has accepted what are simply incompatible background assumptions about the preemptive force of treaties. Consider the following short examples. In Nielsen $v$. Johnson, ${ }^{470}$ the Court observed that "as the treaty-making power is independent of and superior to the legislative power of the states, the meaning of treaty provisions . . . is not restricted by any necessity of avoiding possible conflict with state legislation." 471 Less than a decade later, however, the Court seemingly adopted the opposite view. In Guaranty Trust Co. $v$. United States, ${ }^{472}$ it declared that " $[\mathrm{e}]$ ven the language of a treaty wherever reasonably possible will be construed so as not to override state laws," 473 inexplicably citing Nielsen for support. ${ }^{474}$ And shortly thereafter, in United States $v$. Pink, ${ }^{475}$ the Court observed in dicta that "[i] $\mathrm{t}$ is, of course, true" that treaties "will be carefully construed so as not to derogate from the authority and jurisdiction of the States of this nation unless clearly necessary to effectuate the national policy." 476 Why such a proposition "of course" is true for a treaty, however, the Court failed to explain.

Most recently, the uncertainty over this issue provoked a spirited exchange between otherwise philosophical allies on the Court. In $E l$ Al Israel Airlines, Ltd. v. Tsui Yuan Tseng, ${ }^{477}$ Justice Ginsburg, speaking for the majority, returned to the view advanced in Nielsen on the greater preemptive force of treaties. "Our home-centered preemption analysis," she opined, "should not be applied, mechanically, in construing our international obligations." 478 This provoked a spirited defense from Justice Stevens, echoing the Court's earlier views in Guaranty Trust and Pink. In his view, Justice Ginsburg's approach proceeded from a "novel premise that preemption analysis should be applied differently to treaties than to other kinds of federal law."479

Swirling among these contradictory views is a broader uncertainty over the preemptive force of other forms of positive federal law in the 
foreign affairs arena. Some federal courts have indicated, for instance, that the traditional presumption against preemption should not apply even to federal statutes if they regulate matters of foreign affairs. ${ }^{480}$ And less than a year ago the Supreme Court felt competent in American Insurance Ass' $n$ v. Garamendi ${ }^{481}$ to discern an implied preemptive force even from a sole executive agreement. ${ }^{482}$ This proposition of implied preemption from such a source provoked a strong dissent from the odd alliance of Justices Ginsburg, Stevens, Scalia, and Thomas. ${ }^{483}$

It is likewise difficult to discern any coherent rule regarding the discretionary powers of federal courts under treaties. The scant guidance from the Supreme Court on this score is at best ambiguous. On the one hand, the Court has long acknowledged that federal courts may identify and give effect to implied provisions of self-executing treaties. ${ }^{484}$ A recent formalist opinion by Justice Scalia nonetheless declared that federal courts are not permitted to "supply a casus omissus in a treaty, any more than in a law." "485 To do so, he opined, would represent a "'usurpation of power." "486 Yet the same Justice later penned a majority opinion which clearly assumed that a treaty could confer lawmaking powers on the federal courts, although it concluded that the specific treaty at issue did not do so. ${ }^{487}$

The short of the matter is that substantial uncertainty reigns over the powers of federal courts in relation to the self-executing treaty form of supreme federal law. The goal of this Part is to resolve this uncertainty. The analysis below will show that the existing confusion

480 See, e.g., Hines v. Davidowitz, 312 U.S. 52, 68 (1941) (stating that when Congress legislates in the foreign affairs arena "[a]ny concurrent state power that may exist is restricted to the narrowest of limits"); Nat'l Foreign Trade Council v. Natsios, 181 F.3d 38, 74 (1st Cir. 1999) (observing that "preemption is much more easily found when Congress has passed legislation relating to foreign affairs"), aff d, Crosby v. Nat'l Foreign Trade Council, 530 U.S. 363 (2000). The Supreme Court in Crosby nonetheless expressly declined to address the presumption issue for foreign affairs statutes. See Crosby, 530 U.S. at 374 n.8. For a broader analysis of the propriety of a presumption for or against preemption with regard to foreign affairs statutes, see Goldsmith, supra note 465, at 181-214. Professor Goldsmith argues that when a federal foreign affairs statute also implicates traditional state prerogatives, "the competing presumptions against and for preemption lose coherence and usefulness." Id. at 197.

481123 S. Ct. 2374 (2003).

482 See id. at 2387-88.

483 See id. at 2394-2401 (Ginsburg, J., dissenting).

484 See supra note 163 and accompanying text.

485 Chan v. Korean Air Lines, Ltd., 490 U.S. 122, 135 (1989) (quoting The Amiable Isabella, 19 U.S. (6 Wheat.) 1, 71 (1821)).

486 Id. (quoting The Amiable Isabella, 19 U.S. (6 Wheat.) at 71).

487 Zicherman v. Korean Air Lines Co., 516 U.S. 217, 229 (1996) (holding that the Warsaw Convention governing international air transportation did not "empower [the Court] to develop some common-law rule," although expressing no doubt about the legal premise for such an authorization). 
arises from a failure to appreciate the special nature and functions of self-executing treaties. These attributes substantially undermine the traditional presumptions against federal displacement of state authority in the treaty law context.

\section{B. Treaties and a Presumption of Federal Law}

\section{Dismantling the Presumption Against Preemption}

For statutory exercises of concurrent federal powers, the presumption against preemption stems from the premise that Congress legislates with respect for the historical police powers of the states. ${ }^{488}$ Manifold and substantial reasons support the conclusion that this background assumption-a "clear statement" rule of judicial origin ${ }^{489}$ - should not obtain for exercises by the President and Senate of the federal treaty-making power.

The two most significant reasons for this issue from the unique dual nature of treaties as international law obligations and exercises of exclusive federal power. Externally, treaties are creatures of international law. By their very definition, they involve the creation of international obligations between the United States and its treaty partners. ${ }^{490}$ In conformance with this definition, the Supreme Court repeatedly has declared that the point of departure for treaty interpretation is the mutual intent of the treaty parties. ${ }^{491}$

The international law that governs the formation of these "contractual" 492 obligations-and provides the perspective for our treaty

\footnotetext{
488 See supra notes $463-67$ and accompanying text.

489 See United States v. Bass, 404 U.S. 336, 349 (1971) (referring to the presumption against preemption in these terms).

490 See Vienna Convention on Treaties, supra note 76, art. 26, 1155 U.N.T.S. at 339 (stating that agreements under international law are binding obligations of the treaty partners); Restatement of Foreign Relations, supra note 75, § 321 (same); id. \$301(1) (defining an international agreement as "an agreement between two or more states or international organizations that is intended to be legally binding and is governed by international law").

491 See United States v. Stuart, 489 U.S. 353, 365-66 (1989) (holding that the clear language of a treaty controls, unless the result is inconsistent with the intent or expectations of the signatories); Sumitomo Shoji Am., Inc. v. Avagliano, 457 U.S. 176, 185 (1982) (observing that, in interpreting a treaty, a court's "role is limited to giving effect to the intent of the [t] reaty parties"); Nielsen v. Johnson, 279 U.S. 47, 51 (1929) ("Treaties are to be liberally construed so as to effect the apparent intention of the parties."); see also Maximov v. United States, 299 F.2d 565, 568 (2d Cir. 1962) (observing that treaties should be interpreted "to give the specific words ... a meaning consistent with the genuine shared expectations of the contracting parties"), affd, 373 U.S. 49 (1963).

492 The Supreme Court has often observed the "contractual" nature of an international treaty. See, e.g., Société Nationale Industrielle Aérospatiale v. United States Dist. Court, 482 U.S. 522, 533 (1987) ("In interpreting an international treaty, we are mindful that it is 'in the nature of a contract between nations.' " (quoting Trans World Airlines, Inc. v. Franklin Mint Corp., 466 U.S. 243, 253 (1984))); Washington v. Wash. State Commercial Passenger Fishing Vessel Ass'n, 443 U.S. 658, 675 (1979) ("A treaty . . . is essentially a
} 
partners 493 - does not recognize any concurrent international lawmaking authority for municipal subunits such as U.S. states. ${ }^{494}$ Nor may the United States (absent an express reservation ${ }^{495}$ ) rely on the law of its sub-national units to influence the content of its international treaty commitments. ${ }^{496}$ From its very international birth, therefore, treaty law arises with the background not of state law, but rather of a single, uniform, national law.

This is precisely the premise that animated a recent subtle transition in El Al Israel Airlines. ${ }^{497}$ At issue there was whether the self-executing Warsaw Convention on International Air Transportation ${ }^{498}$ displaced certain types of state law personal injury claims. ${ }^{499}$ Given

contract between two sovereign nations."); Santovincenzo v. Egan, 284 U.S. 30, 40 (1931) (explaining that "treaties are contracts between independent nations"); see also Zicherman, 516 U.S. at 226 (stating that treaties reflect "an agreement among sovereign powers").

493 See El Al Isr. Airlines, Ltd. v. Tsui Yuan Tseng, 525 U.S. 155, 175 (1999) (observing, with regard to the Convention for the Unification of Certain Rules Relating to International Transportation by Air, that "the nation-state, not subdivisions within one nation, is the focus of the Convention and the perspective of our treaty partners"); Fong Yue Ting v. United States, 149 U.S. 698, 711 (1893) ("The only government of this country, which other nations recognize or treat with, is the government of the Union. . . The Constitution of the United States speaks with no uncertain sound upon this subject.").

494 See Restatement of Foreign Relations, supra note $75, \$ 311 \mathrm{cmt}$. a (observing with regard to international agreements that "[a] State of the United States or a subdivision of another state is not a state having capacity to conclude an international agreement").

495 See id. $\S 313$ (stating that a state may attach a reservation to a multilateral treaty subject to certain limitations); see also id. $\mathrm{cmt}$. $\mathrm{f}$ (noting that reservations are rare for bilateral treaties and most often amount to a request for renegotiation of the treaty). Most often, such reservations are attached by the Senate upon its consent to a treaty. See Haver v. Yaker, 76 U.S. (9 Wall.) 32, 35 (1869) (observing that "the Senate are [sic] not required to adopt or reject [a treaty] as a whole, but may modify or amend it"). One example of an express authorization of a federalism reservation is the CISG, which permits a ratifying nation to declare that the treaty shall not extend to one or more political subdivisions (although the United States did not make use of this reservation). See CISG, supra note 173 , art. 93,1489 U.N.T.S. at 76.

496 See Vienna Convention on Treaties, supra note 76, art. 27, 1155 U.N.T.S. at 339 ("A party may not invoke the provisions of its internal law as justification for its failure to perform treaty."); see also Restatement of Foreign Relations, supra note 75, §311(3) ("A state may not invoke a violation of its internal law to vitiate its consent to be bound unless the violation was manifest and concerned a rule of fundamental importance."). A U.S. obligation under international law is not itself a proper subject for adjudication by the federal judiciary. A federal court does not have the authority, for instance, to declare the United States in breach of a treaty for purposes of the international law claims of a foreign treaty partner. See id. $\$ 326 \mathrm{cmt}$. a ("The President has authority to interpret international agreements for the purpose of United States foreign relations since he is the country's 'sole organ' in its international relations and is responsible for carrying out agreements with other nations."). Rather, the point here is that the international law perspective of those who created a treaty provides the context for interpreting the treaty's content when it operates directly as domestic law under the self-execution doctrine.

497525 U.S. 155 (1999).

498 Convention for the Unification of Certain Rules Relating to International Transportation by Air, Oct. 12, 1929, 49 Stat. 3000, T.S. No. 876 (1934), reprinted in 49 U.S.C. $\S 40105$ note $(2000)$.

499 See El Al Isr. Airlines, 525 U.S. at 160. 
this substantive background, the Supreme Court not surprisingly confronted the argument that for treaties as well as statutes, "federal preemption of state law is disfavored generally, and particularly when matters of health and safety are at stake."500 The Court convincingly responded that this view "overlooks ... that the nation-state, not subdivisions within one nation, is the focus of the Convention and the perspective of our treaty partners." 501 It thus rejected the view, advanced by Justice Stevens' dissent, that "a treaty, like an Act of Congress, should not be construed to preempt state law unless its intent to do so is clear." 502

From a domestic law perspective as well, treaties arise in a context that is markedly different than that of statutes. Recall that the entirety of the treaty power is vested in the federal government and expressly denied to the states. ${ }^{503}$ As a result, in creating treaty obligations the treaty-lawmakers do not act in competition with state lawmaking authority. ${ }^{504}$ Moreover, exercises of the self-executing treaty power are not subject to the broad substantive limits that apply to federal statutes. ${ }^{505}$ These fundamental differences with Article I legislation mean that the President and the Senate create treaty law, from a formal perspective at least, ${ }^{506}$ free of concerns about whether they may exceed their lawmaking powers or otherwise encroach on the reserved powers of the states. ${ }^{507}$

\footnotetext{
$500 \quad$ Id. at 175.

$501 \quad I d$.

502 Id. at 181 (Stevens, J., dissenting).

503 See supra notes 53-54 and accompanying text (discussing the prohibition on state treaty-making in Article I, Section 10, of the Constitution).

504 See Goldsmith, supra note 465, at 188-89 (drawing a distinction between Congress's concurrent legislative powers in Article $I$ and the prohibition on treaty making by the states, and observing that "Article I, Section 10 reflects a decided preference for federal over state regulation with respect to some of the traditional 'high'-agenda foreign relations issues concerning war, peace, and diplomacy").

505 See supra notes $337-46$ and accompanying text.

506 As a political matter, the close institutional alliance with the States will mean that the Senate will often act to protect their interests in the treaty-making process. For more on this point, see infra notes 530-31 and accompanying text.

507 Even Justice Scalia has emphasized the important distinction with regard to treaties that the Constitution expressly denies such a power to the states. See Itel Containers Int'l Corp. v. Huddleston, 507 U.S. 60, 80 (1993) (Scalia, J., concurring in part) (emphasizing with regard to both the interstate and the foreigu aspects of the Commerce Clause that "the basic point [is] that the Commerce Clause is a power conferred upon Congress (and not a power denied to the States)"); Tyler Pipe Indus., Inc. v. Wash. State Dep't of Revenue, 483 U.S. 232, 261 (1987) (Scalia, J., concurring in part and dissenting in part) (observing, in a spirited criticism of the dormant Commerce Clause, that there is "no correlative denial of power over commerce to the States in [Article 1, Section] 10, as there is, for example, with the power to . . make treaties"). Justice Scalia, of course, is one of the foremost critics of judicial interference with state regulatory powers. See, e.g., id. at 262-64 (Scalia, J., concurring in part and dissenting in part) (arguing that the Commerce Clause can only be read to confer regulatory power on Congress, rather than to negative such power to the states); Am. Trucking Ass'ns, Inc. v. Smith, 496 U.S. 167, 202-03 (1990)
} 
Although not yet fully appreciated in this context, several existing meta-rules of interpretation are consistent with the premise that courts should accord treaties greater deference than other forms of domestic law. For instance, the Supreme Court has long interpreted statutes with a strong presumption that Congress does not intend to violate treaties. ${ }^{508} \mathrm{~A}$ similar presumption obtains regarding the extraterritorial application of federal statutes, ${ }^{509}$ precisely because of a concern about unintentional interference with foreign affairs matters. ${ }^{510}$ More broadly, the Supreme Court has held that courts should interpret federal statutes to avoid interference with U.S. international law obligations in general. ${ }^{511}$

This framework for understanding the preemptive force of treaty law also sits comfortably on the broader foundation of the exclusivity of federal power in shaping U.S. foreign relations. As examined in detail above, the Supreme Court throughout its history has emphasized the dominance of federal power over the nation's foreign rela-

(Scalia, J., concurring in judgment) (arguing that the Commerce Clause only preempts state law to the extent that Congress exercises the Clause to preempt state law).

508 See Trans World Airlines, Inc. v. Franklin Mint Corp., 466 U.S. 243, 252 (1984) ("There is . . . a firm and obviously sound canon of construction against finding implicit repeal of a treaty in ambiguous congressional action. 'A treaty will not be deemed to have been abrogated or modified by a later statute unless such purpose on the part of Congress has been clearly expressed.' (quoting Cook v. United States, 288 U.S. 102, 120 (1933) and citing, inter alia, Washington v. Wash. Commercial Passenger Fishing Vessel Ass'n, 443 U.S. 658,690 (1979))); see also id. (observing that "[l] egislative silence is not sufficient to abrogate a treaty" (citing Weinberger v. Rossi, 456 U.S. 25, 32 (1982))).

509 See Equal Employment Opportunity Comm'n v. Arabian Am. Oil Co., 499 U.S. 244, 248 (1991) ("Congress legislates against the backdrop of the presumption against extraterritoriality.").

510 See id. at 248 (stating that the presumption against extraterritorial application of a statute "serves to protect against unintended clashes between our laws and those of other nations which could result in international discord"); see also Jeffrey E. González-Pérez \& Douglas A. Klein, The International Reach of the Environmental Impact Statement Requirement of the National Environmental Policy Act, 62 GEO. WASH. L. REv. 757, 774 (1994) (observing that the presumption against extraterritorial application advances the interests of international comity); Jason Jarvis, A New Paradigm for the Alien Tort Statute Under Extraterritoriality and the Universality Principle, 30 PEPP. L. REv. 671, 699-700 (2003) (noting that the presumption "'serves to protect against unintended clashes between our laws and those of other nations which could result in international discord'" (quoting Arabian Am. Oil Co., 499 U.S. at 248)).

511 See, e.g., Murray v. Schooner Charming Betsy, 6 U.S. (2 Cranch) 64, 118 (1804) (" $[A] n$ act of Congress ought never to be construed to violate the law of nations if any other possible construction remains ...."). But see Curtis A. Bradley, The Charming Betsy Canon and Separation of Powers: Rethinking the Interpretive Role of International Law, 86 GEo. L.J. 479, 517-24 (1998) (questioning the propriety of this interpretive rule). There is also strong sense in applying a parallel notion to state law. See Clark, supra note 2, at 1357 (citing Schooner Charming Betsy and arguing that "the constitutional structure suggests that states generally lack legislative competence to prescribe binding rules of decision in situations in which federal courts would interpret a federal statute narrowly to avoid violations of international law"). 
tions. ${ }^{512}$ Flipping the federalism equation, it likewise has stressed the correlative displacement of state lawmaking authority in the field. ${ }^{513}$ Indeed, as one commentator has observed, the proposition of exclusive federal lawmaking power over foreign relations is so clear, and has been reaffirmed so many times, "that citations to establish the point seem hardly necessary." 514

The precise "negative" force of this exclusive power over foreign affairs in the absence of formal federal lawmaking is the subject of substantial controversy. ${ }^{515}$ It is not necessary for present purposes, however, to wade into the specifics of the heated debates over a "dormant foreign Commerce Clause" 516 or a "dormant foreign affairs power." 517 Nonetheless, the very existence of such arguments over unused federal powers sets a valuable context for understanding the preemptive force of formal exercises of federal lawmaking authority in the field.

When the federal government exercises its exclusive authority over treaty-making, it acts at the apex of its power to displace state

\footnotetext{
512 See supra notes 68-71 and accompanying text.

513 See supra notes $69-71$ and accompanying text.

514 Golove, supra note 10 , at 1300 . For other scholarly observations to the same effect,
} see Henkin, supra note 384, at 150 ("At the end of the twentieth century as at the end of the eighteenth, as regards U.S. foreign relations, the states 'do not exist.' "); 1 LAURENCE $H$. TRIBE, AMERICAN CONSTITUTIONAL LAW \$ 4-5 (3d ed. 2000) ("[S] tate action, whether or not consistent with current federal foreign policy, that distorts the allocation of responsibility to the national government for the conduct of American diplomacy is void . . .").

515 See supra notes 305-06 and accompanying text (describing this controversy).

516 See Japan Line, Ltd. v. County of Los Angeles, 441 U.S. 434, 449 (1979) (concluding that the risk of multiple state law rules and the need of the country to "speak with one voice when regulating commercial relations with foreign governments" "meant that the dormant foreign Commerce Clause preempted state taxation of international containers (quoting Michelin Tire Corp. v. Wages, 423 U.S. 276, 285 (1976))); see also Buttfield v. Stranahan, 192 U.S. 470, 496 (1904) (noting that Congress has "plenary power" over foreign commerce); Bowman v. Chi. \& N.W. Ry. Co., 125 U.S. 465, 482 (1888) (

It may be argned [that] the inference to be drawn from the absence of legislation by Congress on the subject excludes state legislation affecting commerce with foreign nations more strongly than that affecting commerce among the States. Laws which concern the exterior relations of the United States with other nations and governments are general in their na. ture, and should proceed exclusively from the legislative authority of the nation.

). But see Container Corp. of Am. v. Franchise Tax Bd., 463 U.S. 159, 189-96 (1983) (declining to follow Japan Line with regard to the dormant foreigu Commerce Clause); see also Itel Containers Int'l Corp. v. Huddleston, 507 U.S. 60, 71-76 (1993) (following Container Corp. and affirming a state sales tax on international cargo container leases).

517 See Zschernig v. Miller, 389 U.S. 429, 432-36 (1968) (holding that any state action having more than an incidental effect on the nation's foreign affairs is preempted, even if it does not conflict with any affirmative federal activity in the field); see also Am. Ins. Ass'n v. Garamendi, 123 S. Ct. 2374, 2388 (2003) ('[S] tate action with more than incidental effect on foreign affairs is preempted, even absent any affirmative federal activity in the subject area of the state law, and hence without any showing of conflict."). 
law. ${ }^{518}$ The essence of a treaty, as Justice Holmes famously observed in Missouri v. Holland, is that it addresses a matter that is of "national interest." 519 Regardless of the substantive subject, in other words, by incorporating a matter within the country's international "contractual" obligations, the federal government transforms that matter into one of national concern. And because the federal government forms treaties through negotiation with a foreign power, a treaty by its nature reflects an exercise of federal power that is beyond the "traditional competence" of the states. ${ }^{520}$

To be sure, a self-executing treaty may regulate a substantive subject-such as commercial law ${ }^{521}$ - that states have historically addressed. But by including the subject in our nation's formal international obligations, the treaty-lawmakers elevate it in a unique way to a matter of national concern. That is, in contrast to the internal focus of a standard federal statute, the reference point for a treaty is the external relationship with a foreign power. It is with reference to this external relationship that even the domestic law incidents of the treaty (through the self-execution doctrine) must be weighed and measured. Almost from its very nature, therefore, state law regulation

518 See United States v. Pink, 315 U.S. 203, 230-31 (1942) (declaring that "state law must yield when it is inconsistent with, or impairs . . the superior Federal policy evidenced by a treaty or international "compact or agreement").

519 See Missouri v. Holland, 252 U.S. 416, 433-35 (1920). For a broader examination of the background and meaning of Missouri $v$. Holland, see Golove, supra note 10, at 1257-66. There are many judicial analyses of Missouri $v$. Holland's import. See, e.g., Santovincenzo v. Egan, 284 U.S. 30, 40 (1931) ("The treaty-making power is broad enough to cover all subjects that properly pertain to our foreign relations . . . .); Asakura v. City of Seattle, 265 U.S. 332, 341 (1924) ("The treaty-making power of the United States is not limited by any express provision of the Constitution, and, though it does not extend 'so far as to authorize what the Constitution forbids,' it does extend to all proper subjects of negotiation between our government and other nations." (quoting Geofroy v. Riggs, 133 U.S. 258, 267 (1890))); In re Ross, 140 U.S. 453, 463 (1891) ("The treaty-making power vested in our government extends to all proper subjects of negotiation with foreign governments."); Geofroy, 133 U.S. at 266-67 ("That the treaty power of the United States extends to all proper subjects of negotiation between our government and the governments of other nations, is clear." (citing Hauenstein v. Lynham, 100 U.S. 483 (1879); Chirac v. Chirac's Lessee, 15 U.S. (2 Wheat.) 259 (1817); Ware v. Hylton, 3 U.S. (3 Dall.) 199 (1796))).

520 See U.S. Const. art. 1, $\S 10, \mathrm{cl} .1$ (forbidding states from concluding treaties); $c f$. United States v. Locke, 529 U.S. 89, 108 (2000) (observing that the “'assumption' of nonpre-emption is not triggered when the State regulates in an area where there has been a history of significant federal presence" (citing Rice v. Santa Fe Elevator Corp., 331 U.S. 218, 230 (1947))); supra notes 463-67 and accompanying text (noting that the presumption against preemption applies where Congress legislates in areas of traditional state competence). In a cryptic footnote in Garamendi, the Supreme Court hinted that whether a subject matter is one of "traditional state responsibility" may remain relevant for purposes of "dormant foreign affairs" preemption. See 123 S. Ct. at 2389 n.11. It declined, however, to address the force of the competing federal interests even wben the subject is one of traditional state competence. See $i d$.

521 See supra notes $173-80$ and accompanying text (describing the variety of self-executing treaties in the field of commercial law). 
of a matter within the outer boundaries ${ }^{522}$ of a treaty will tend to "stand [ ] as an obstacle" to the treaty's foreign affairs purposes. ${ }^{523}$

Indeed, only this past term the Supreme Court emphasized the preemptive force of a sole executive agreement, which (lacking any legislative imprimatur at all) reflects perhaps the weakest form of federal foreign affairs law. ${ }^{524}$ The Court in Garamendi found that the President, acting alone, had the power to create a foreign affairs policy through such a vehicle, ${ }^{525}$ and it concluded that even the President's unarticulated purposes had the power to displace state law. ${ }^{526}$ The preemptive force of a formal treaty by its nature is even broader, for it is founded on express (rather than implied ${ }^{527}$ ) constitutional authority and involves the cooperation of both the executive and legislative branches in creating federal law.

In some cases, the treaty-lawmakers will clear away any doubt over the interests of uniformity through a formal treaty provision. Such an express uniformity directive-similar to that in a separate provision of the UN Sales Convention and its progeny ${ }^{528}$ - renders the operation of diverse state law rules in direct conflict with an "identifiable 'federal

522 The phrase "outer boundaries" refers to a treaty's general subject matter. To pick an absurd example, a self-executing treaty on international sales of goods does not create a presumption in favor of preemption of state law for international marriages. The presumption would only operate to fill internal gaps in the treaty and to define the immediate edges of a treaty's scope. See, e.g., CISG, supra note 173, art. 1, 1489 U.N.T.S. at 60 (defining the "sphere of application" of the UN Sales Convention).

523 See Crosby v. Nat'l Foreign Trade Council, 530 U.S. 363, 373 (2000) (concluding that state law is preempted when it "stands as an obstacle to the accomplishment and execution of the full purposes and objectives of Congress" (quoting Hines v. Davidowitz, 312 U.S. 52, 67 (1941))); see also supra notes 295-97 and accompanying text (describing "obstacle preemption").

524 See Garamendi, 123 S. Ct. at 2392 n.14 (observing that, when acting through a sole executive agreement, the President "does not have the 'plenitude of Executive authority'" that exists when agreements have express congressional authorization (quoting Crosby, 530 U.S. at 376)).

525 Id. at $2387-88$.

526 Id. at $2390-91$.

527 Id. at 2386 (holding that "the source of the President's power to act in foreign affairs does not enjoy any textual detail" but observing that "our cases have recognized that the President has authority to make 'execuuve agreements' with other countries" (citing, inter alia, Dames \& Moore v. Regan, 453 U.S. 654, 679, 682-83 (1981))).

528 See, e.g., United Nations Convention on the Assignment of Receivables in International Trade, supra note 179, art. 7(1), 41 I.L.M. at 781 (providing that interpreters of the convention must consider "the need to promote uniformity in its application"); Convention on lndependent Guarantees and Stand-by Letters of Credit, supra note 179, art. 5, 35 I.L.M. at 742 (same); UNIDROIT Convention on International Factoring, supra note 179, art. 4(1), 27 1.L.M. at 945 (same); CISG, supra note 173, art. 7(1), 1489 U.N.T.S. at 61 (same); see also Asante Techs., 1nc. v. PMCSierra, Inc., 164 F. Supp. 2d 1142, 1151-52 (N.D. Cal. 2001) (concluding that the UN Sales Convention's uniformity directive reflected the treaty-lawmakers' intent to preempt state law claims within the scope of the Convention). 
policy or interest." ${ }_{529}$ In such cases, the arguments for federal court interstitial lawmaking to fulfill the interests of national uniformity are at their most compelling.

Finally, the special procedural protections of state interests in the treaty-making process address any lingering doubts about unintended displacements of state law. With the fortifying force of a minority veto, the Senate's role as a representative of the states in the treatymaking process is significantly more powerful than in standard Article I lawmaking. ${ }^{530}$ There is also strong evidence that the Senate uses this power aggressively, particularly in the increasingly common practice of attaching federalism and non-self-execution reservations to certain categories of treaties. ${ }^{531}$ In light of this power and practice, the Senate's silence regarding the relationship of a treaty with state law should mean more than congressional silence in the statutory context.

The result of all of these considerations is that the traditional "presumption against preemption" of state law should have no place in the application of treaty law. To the contrary, the external, international perspective of treaty-making, the exclusivity of the federal treaty-making power (which is neither substantively limited nor in competition with state law), and the force of the formal expression of a national interest through a treaty all militate for a background assumption in favor of federal law for matters within the scope of a selfexecuting treaty.

\section{Treaties and Interstitial Judicial Lawmaking}

\section{a. The Uniquely Federal Interest in Contractual Obligations of Treaties}

The determination that treaties should have a broad preemptive scope does not resolve the distinct and weightier issue of federal lawmaking powers in the same context. Careful analysis nonetheless reveals that, as compared with implied authorizations in domestic law statutes, ${ }^{532}$ a more accommodating approach toward interstitial federal court lawmaking is appropriate for self-executing treaties.

529 See Boyle v. United Techs. Corp., 487 U.S. 500, 507 (1988) (quoting Wallis v. Pan Am. Petroleum Corp., 384 U.S. 63, 68 (1966)).

530 See supra notes 401-04 and accompanying text (describing the Senate's special role as protector of state interests in the treaty-making process).

531 For an examination of such reservations with regard to human rights treaties, see generally Bradley \& Goldsmith, supra note 10.

532 This section expands significantly on my earlier observations on the subject. See Van Alstine, supra note 19, at 1286-94 (arguing, with specific reference to express delegations of common law powers under treaties, that such delegations satisfy constitutional concerns if they reflect a specific intent of the treaty-lawmakers). As explained below, the necessary intent for implied delegations is merely that a specific matter be included within the scope of a self-executing treaty, subject to any special separation of powers concerns. 
The analysis here properly begins with background provided by Banco Nacional de Cuba v. Sabbatino. ${ }^{533}$ Recall that in Sabbatino the Supreme Court recognized that core issues "regarding the competence and function of the Judiciary and the National Executive in ordering our relationships with other members of the international community must be treated exclusively as an aspect of federal law."534 It likewise emphasized that a variety of constitutional and statutory provisions "reflect[ ] a concern for uniformity in this country's dealings with foreign nations and indicat[e] a desire to give matters of international significance to the jurisdiction of federal institutions." 535 Therefore, even in the absence of formal guidance from Congress and the President, federal courts are empowered to resolve such issues as a matter of federal common law. 536

A strong federal interest in a particular subject does not alone authorize courts to make federal law. ${ }^{537}$ But the exclusive federal power over the nation's international relations also represents perhaps the most prominent field of "uniquely federal interests." 538 In such cases, the Supreme Court has emphasized, "[t]he conflict with federal policy need not be as sharp as that which must exist for ordinary pre-emption." 539 And where federal exercises of lawmaking powers "'by their nature are and must be uniform in character throughout the Nation," they likewise "necessitate formulation of controlling federal rules" by federal courts. ${ }^{540}$

For formal exercises of the federal foreign affairs power through treaties, the requisite conflict with the operation of state law arises

$533 \quad 376$ U.S. 398 (1964).

534 Id. at 425; see also Tex. Indus., Inc. v. Radcliff Materials, Inc., 45 I U.S. 630, 641 (1981) (observing that one "enclave" of federal common law covers "international disputes implicating ... relations with foreign nations").

535 Sabbatino, 376 U.S. at 427 n.25 (citing U.S. Const. art. I, § 8, cI. 3, I0; art. II, \$§ 2, 3; art. III, § 2; 28 U.S.C. $\$ \$ 1251$ (a) (2), (b) (1), (b) (3), 1332(a)(2), 1333, 1350-51 (1964)); see also Bd. of Trs. v. United States, 289 U.S. 48, 59 (1933) ("In international relations and with respect to foreign intercourse and trade the people of the United States act through a single government with unified and adequate national power.").

536 See Sabbatino, 376 U.S. at 425-27.

537 See discussion supra notes 280-81 and accompanying text.

538 See discussion supra Part II.B.2 (analyzing the recognized enclaves of federal common law).

539 Boyle v. United Techs. Corp., 487 U.S. 500, 507 (1988) (citing Rice v. Santa Fe Elevator Corp., 331 U.S. 218, 230 (1947)).

540 United States v. Kimbell Foods, Inc., 440 U.S. 715, 728 (1979) (quoting United States v. Yazell, 382 U.S. 341 , 354 (1966)); see also Boyle, 487 U.S. at 508 (holding that where federal interests in a field require a uniform federal rule, "the entire body of state law applicable to the area conflicts and is replaced by federal rules" (citing Clearfield Trust Co. v. United States, 318 U.S. 363, 366-67 (I943))). 
from the vital interests of uniformity. ${ }^{541}$ By their very nature, the international "contractual" obligations a treaty creates must have a uniform national content in relation to the foreign treaty partners. ${ }^{542} \mathrm{~A}$ conflict with the operation of state law springs from the simple fact that otherwise over fifty different (and potentially inconsistent) state law rules may define the nation's treaty obligations. The Supreme Court's observation about the federal government's rights and obligations with respect to the commercial paper that it issues is equally apt here: "The application of state law . . . would subject the rights and duties of the United States to exceptional uncertainty. It would lead to great diversity in results by making identical transactions subject to the vagaries of the laws of the several states. The desirability of a uniform rule is plain." ${ }^{443}$ Thus, if a matter is presumptively within the scope of a treaty, the resolution of related disputes over content and application also presumptively requires a uniform rule..$^{544}$ When unintended gaps emerge within the intended scope of a treaty, therefore, it is entirely appropriate for federal courts to supply as necessary a uniform, federal law solution, ${ }^{545}$ in the absence of more formal guidance from the treaty's text, context, and drafting history. ${ }^{546}$

541 See Boyle, 487 U.S. at 508 ("In some cases, for example where the federal interest requires a uniform rule, the entire body of state law applicable to the area conflicts and is replaced by federal rules." (citing Clearfield Trust, 318 U.S. at 366-67)).

542 See supra note 491 and accompanying text (citing authority for the proposition that the primary rule of treaty interpretation is to give effect to the mutual intent of the treaty parties).

543 Clearfield Trust, 318 U.S. at 367.

544 As some courts have recognized, this point may be equally applicable to federal common law under legislation that directly implements a treaty. See In re Estate of Marcos Human Rights Litig., 910 F. Supp. 1460, 1469 (D. Haw. 1995) (observing with regard to the implementing legislation for the Torture Convention, the Torture Victim Protection Act (TVPA), that because "Congress in the TVPA offered no methodology as to how damages should be determined, federal courts are free to and should create federal common law to provide justice for any injury contemplated by the Alien Tort Statute and the TVPA or treaties dealing with the protection of human rights"), affd sub nom. Hilao v. Estate of Marcos, 103 F.3d 767 (9th Cir. 1996); see also Chiminya Tachiona v. Mugabe, 216 F. Supp. 2d 262, 267 (S.D.N.Y. 2002) (same).

545 Cf. McGurl v. Trucking Employees of N. Jersey Welfare Fund, Inc., 124 F.3d 471, 481 (3d Cir. 1997) ("' [If] state law is preempted and no specific federal provision governs, a court is forced to make law or leave a void where neither state nor federal law applies. In such a situation it is a reasonable inference that Congress intended some law, and therefore federal law, to apply.'" (quoting Wayne Chemical, Inc. v. Columbus Agency Serv. Corp., 426 F. Supp. 316, 322 (N.D. lnd. 1977))).

546 Scholars have offered a number of comprehensive analyses of the accepted means of treaty interpretation. See, e.g., Bederman, supra note 25 (examining methods of treaty interpretation and recent approaches of the Rehnquist Court); Van Alstine, supra note 25, at 738-61 (advocating a code-like interpretive model for certain classes of treaties); James C. Wolf, Comment, The Jurisprudence of Treaty Interpretation, 21 U.C. DAvis L. REv. 1023 (1988) (analyzing interpretation jurisprudence with respect to three classifications of treaty law and suggesting revisions to the Revised Restatement of the Law of Foreign Relations). 
Indeed, a compelling analogy already exists in a well-established "enclave" of federal common law. 1t is now established jurisprudence that the "obligations to and rights of the United States under its contracts are governed exclusively by federal law." 547 Where, then, a disputed issue lacks a legislative solution, federal courts have a constitutional responsibility to supply a consistent, uniform rule of federal law. ${ }^{548}$ And as the Supreme Court made clear in Boyle, where an issue implicates the contractual rights or obligations of the United States, federal courts retain this responsibility even if such issues arise in disputes solely between private parties. ${ }^{549}$

An international treaty likewise represents the contractual obligations of the United States, in this case in relation to a foreign nation under international law. ${ }^{550}$ Like its domestic law counterpart, therefore, the identification of the federal government's treaty obligations is a matter of uniquely federal interest, which by its nature requires uniform national rules. ${ }^{551}$ It emerges from a mere statement of the proposition that the possible application of multiple, potentially in-

547 Boyle v. United Techs. Corp., 487 U.S. 500, 504 (1987) (citing United States v. Little Lake Misere Land Co., 412 U.S. 580, 592-94 (1973); Priebe \& Sons, lnc. v. United States, 332 U.S. 407, 411 (1947); Nat'l Metro. Bank v. United States, 323 U.S. 454, 456 (1945); Clearfield Trust, 318 U.S. at 366-67). The Boyle Court recognized the propriety of federal common law in such private disputes even in the face of a spirited dissent by Justice Brennan based on the power of Erie. See Boyle, 487 U.S. at 517 (Brennan, J., dissenting) (arguing that "Erie was deeply rooted in notions of federalism, and is most seriously implicated when, as here, federal judges displace the state law that would ordinarily govern with their own rules of federal common law").

548 See, e.g., Little Lake Misere Land, 412 U.S. at 593 ("[T] seek legal redress for duly authorized proprietary transactions "is a federal right, so that the courts of the United States may formulate a rule of decision." (quoting Henry J. Friendly, In Praise of Erie-And of the New Federal Common Law, 39 N.Y.U. L. Rev. 383, 410 (1964))); see also Boyle, 487 U.S. at 504-08 (holding that, in the absence of congressional guidance, federal courts may exercise lawmaking powers regarding contractual obligations of the United States (citing, inter alia, Clearfield Trust, 318 U.S. at 366-67)).

549 See Boyle, 487 U.S. at 506 (holding that "it is plain that the Federal Government's interest in the [contractual] procurement of equipment is implicated by suits such as the present one-even though the dispute is one between private parties"). Perhaps Litlle Lake Misere Land makes the clearest statement of the propriety of federal common law in this area:

Since Erie, and as a corollary of that decision, we have consistently acted on the assumption that dealings which may be 'ordinary' or 'local' as between private citizens raise serious questions of national sovereignty when they arise in the context of a specific constitutional or statutory provision; particularly is this so when transactions undertaken by the Federal Government are involved .... In such cases, the Constitution or Acts of Congress 'require' otherwise than that state law govern of its own force.

412 U.S. at $592-93$.

550 See supra notes 490-96 and accompanying text.

551 See Restatement of Foreicn Relations, supra note $75, \S 325 \mathrm{cmt}$. d ("Treaties that lay down rules to be enforced by the parties through their internal courts or administrative agencies should be construed so as to achieve uniformity of result despite differences between national legal systems."). 
consistent, state law rules directly conflicts with the national interest in a uniform definition of our treaty obligations with foreign states. ${ }^{552}$

In addition, and paralleling the proposition recognized in Boyle, federal court lawmaking is appropriate even with regard to the rights of private parties derived from self-executing treaties, because treaties implicate the obligations of the United States. ${ }^{553}$ Indeed, the argument for such interstitial judicial lawmaking is even more compelling in the treaty context. Private rights under self-executing treaties exist solely because of U.S. contractual obligations first established in the treaty. By definition, therefore, these private rights derive from, and are limited by the content of, the United States' treaty obligations. Significantly, these international obligations exist in relation to a sovereign entity that is external to our national polity. ${ }^{554}$

Finally, existing interpretive institutions already prefer uniform national solutions for unresolved treaty issues. First, from its earliest treaty cases, the Supreme Court has declared that federal courts should be open to a liberal, purposive interpretation of treaties. ${ }^{555}$

552 The issue in dispute must, of course, also be within the intended scope of the treaty obligations. See discussion infra Part IV.B.2.b.

553 This is true even though for purely private law treaties the international obligations are fulfilled not through executive branch conduct, but rather by judicial resolution of private disputes. This aspect of even private treaties once again emphasizes the differences between self-executing treaties and standard Article I legislation. Through such a treaty, the United States obtains benefits for its internationally active citizens. See supra notes 143, 323-24 and accompanying text. It could, of course, simply pass domestic legislation that is substantially similar in content to an international treaty. But if it does not formally ratify the treaty in accordance with constitutionally prescribed procedures and if the legislation does not fully conform to the limitations of the treaty, the United States would not be a "Contracting State" for purposes of other nations. See, e.g., CISG, supra note 173, art. 1 (1) (a), 1489 U.N.T.S. at 60 (describing the scope of the treaty with reference to which nations are "Contracting States"). As a result, the putative "treaty partners" would not be obligated to grant the substantive benefits of the treaty to U.S. citizens.

554 This is not to say that all contractual obligations under treaties are of the same nature. Some treaties do not involve any continuing obligations for the executive branch of the United States in its international conduct as a sovereign entity. See Van Alstine, supra note 19, at 1279-80. Prominent examples include commercial law treaties such as the United Nations Convention on Contracts for the International Sale of Goods, see CISG, supra note 173, whose operative provisions create only rights and obligations between private parties and impose no continuing substantive obligations on the United States. See Van Alstine, supra note 25, at 700-01. As a result, the application of such treaties to private disputes requires a different interpretive approach. Even these treaties involve sovereign obligations of the United States, although those obligations are fulfilled through a faithful application by domestic courts. See, e.g., infra notes 569-70 and accompanying text (noting that even private law treaties may be the subject of international law disputes).

555 See Nielsen v. Johnson, 279 U.S. 47, 52 (1929) ("When a treaty provision fairly admits of two constructions, one restricting, the other enlarging rights which may be claimed under it, the more liberal interpretation is to be preferred . . . .); Shanks v. Dupont, 28 U.S. (3 Pet.) 242, 249 (1830) (rejecting a narrow interpretation of individual rights under a treaty and concluding that "[i]f the treaty admits of two interpretations, and one is limited, and the other liberal; one which will further, and the other exclude private rights; why should not the most liberal expositions be adopted?"). 
Thus, in a recent formulation, the Court stated that "a treaty should generally be 'construe[d] . . . liberally to give effect to the purpose which animates it' and ... '[e]ven where a provision of a treaty fairly admits of two constructions, one restricting, the other enlarging, rights which may be claimed under it, the more liberal interpretation is to be preferred." "556 Second, the Court has found that interests of national uniformity require federal courts to accord "considerable weight" to interpretive opinions by the courts of our treaty partners. ${ }^{557}$ These findings confirm the external, international perspective required for the interpretation of U.S. treaty obligations. Considerations of uniformity in our foreign policy likewise warrant federal courts giving calibrated respect to reasonable interpretive opinions of the President, ${ }^{558}$ although no such deference applies to Congress with regard to Article I legislation. ${ }^{559}$

\section{b. Differentiating Gaps Intra Legem from Gaps Praeter Legem}

The mere existence of a treaty does not, of course, transform all potentially related issues into matters of federal common law. Rather, a proper appreciation of the judicial role requires a careful understanding of the difference between so-called gaps intra legem and gaps praeter legem. The former involve matters which are logically within the outer boundaries of a treaty, but which the drafters nonetheless intentionally excluded from its scope. ${ }^{560}$ In such cases, the gaps in the treaty reflect an express determination by the treaty-lawmakers not to include certain issues within the international obligations of the United States. For these issues, therefore, courts may properly look to the otherwise applicable domestic rules of decision, including, in the proper case, state law. ${ }^{\mathbf{5 6 1}}$

556 United States v. Stuart, 489 U.S. 353, 368 (1989) (quoting Bacardi Corp. of Am. v. Domenech, 311 U.S. 150, 163 (1940)). However, it is open to doubt whether this rhetoric has influenced the practical outcome of treaty interpretation cases in the Supreme Court. See Van Alstine, supra note 25, at 725 n.153.

557 See El Al Isr. Airlines, Ltd. v. Tsui Yuan Tseng, 525 U.S. 155, 175 (1999) (holding that "[d] ecisions of the courts of other Convention signatories corroborate" the Court's interpretation of the Warsaw Convention on international air transportation); Air Fr. v. Saks, 470 U.S. 392, 404 (1985) (stating with regard to treaty interpretation that " the opinions of our sister signatories [are] to be entitled to considerable weight' (quoting Benjamins v. British European Airways, 572 F.2d 913, 919 (2d Cir. 1978))).

558 See supra note 330 and accompanying text.

559 See supra note 329 and accompanying text.

560 Consider again the UN Sales Convention as an example. Although this treaty broadly governs rights and obligations under international sales transactions, its Article 2 expressly excludes a variety of transaction categories from its scope. See CISG, supra note 173 , art. 2, 1489 U.N.T.S. at 60.

561 It is nonetheless possible that federal common law would be appropriate even for such issues. The justification for doing so, however, would have to emanate from a source other than the treaty power. One example is a treaty that addresses the liability of a state for expropriation, but does not do so comprehensively. If a matter intentionally excluded 
Gaps praeter legem, on the other hand, involve substantive issues that remain within the regulatory scope of a treaty. In this case, even though a matter is within the treaty's intended scope, the treaty-makers-through oversight, inadvertence, or otherwise-have unintentionally failed to provide formal guidance on its resolution. In other words, the unresolved issue remains subject to the substantive reach of the treaty. For gaps praeter legem, then, the treaty-lawmakers have determined for federalism purposes that rules of a federal origin will displace state law. Before this is so, the paramount interests of national uniformity discussed above will-in the absence of guidance from the treaty's text, context, or drafting history ${ }^{562}$ - militate in favor of application of a federal rule of decision supplied by federal courts. ${ }^{563}$

Determining the character of a particular gap will often be a difficult enterprise. Separation of powers concerns may also counsel special discretion for some treaties-a subject addressed in the final section below. ${ }^{564}$ But it is also precisely to resolve such doubtful issues that the background assumption of treaty preemption of state law operates to favor a praeter legem approach for gaps in a treaty's regulatory scheme. ${ }^{565}$

\section{c. Interstitial Lawmaking and Error Costs}

Finally, consideration of the costs of interpretive error also supports a more accommodating approach to interstitial lawmaking powers under treaties. Consider first an erroneous decision by a federal

from the scope of the treaty-e.g., an expropriation of assets concerning a state's natural resources-comes before a court, the basic proposition established in Sabbatino would require resolution as a matter of federal common law, irrespective of the delegation argument advanced in the text. See Banco Nacional de Cuba v. Sabbatino, 376 U.S. 398, 427-28 (1964) (holding that, without a treaty governing the matter, the "act of state doctrine" precludes courts from resolving a dispute over a foreign sovereign government taking property within its own territory); supra notes 281-83 and accompanying text.

562 Federal courts need not supply a rule of their own making, of course, if the text and drafting history of a treaty reflect an intent of the drafters in favor of a particular solution to a disputed issue. See Restatement of Foreign Relations, supra note 75, $\$ 325$ $\mathrm{cmt}$. b ("For the purpose of interpreting an agreement, the context comprises, in addition to the text, including its preamble and annexes, . . . any other agreement between the parties in connection with the conclusion of the agreement . . ..").

563 The foundation of a formal treaty also dissipates the concerns of some critics about unbridled exercises of federal common law powers solely because of the international law context. See Bradley \& Goldsmith, supra note 10, at 463-64 (criticizing the "modern position" that federal courts have the power to apply norms of customary international law as an element of federal common law). For the law within the scope of a treaty, federal courts do not derive their lawmaking authority from the general foreign affairs "enclave" of federal common law. Rather, the exercise of such powers is appropriate only when the substantive content of the treaty expressly or impliedly so requires or provides.

564 See discussion infra Part IV.C.

565 See discussion supra Part I.A-B (analyzing the case for a broader assumption that self-executing treaties displace state law). 
court not to provide a uniform federal law solution. If the treatylawmakers nonetheless intended the matter to fall within the scope of a treaty, the result of such an erroneous determination is that fiftyplus (potentially inconsistent) state law rules will give content to a matter of federal law-a proposition the Supreme Court has rejected at least since Martin v. Hunter's Lessee in 18I6.566

In the process, the error also would amount to a breach of our international treaty obligations. That is, if treaty-lawmakers designed a treaty to govern an issue, but due to inadvertence or otherwise did so only imperfectly, a decision to allow diverse state law solutions would greatly enhance the risk of international discord with the nation's treaty partners. Judicial determinations, like the actions of any other governmental institution, may violate treaty obligations. ${ }^{567}$ To cure the error would also require the cooperation of sovereign entities external to our polity-the treaty partners. Such a renegotiation may be difficult in some cases, and practically impossible for broad multilateral treaties. ${ }^{568}$

Even for private law treaties, judicial interpretive errors may engender significant international disputes. Witness, for instance, the controversies that arose from alleged failures of German courts to apply faithfully the Convention on International Child Abduction. ${ }^{569} \mathrm{Al}-$ though the disputes arose solely between private litigants asserting treaty rights, they led to negotiations between the United States and Germany at the highest levels of government. ${ }^{570}$

On the other hand, an error in favor of federal law will incur less serious implications. In this case, treaty-lawmakers may not have intended an issue to be within the scope of a treaty in the first place. If a court erroneously decided otherwise, however, a simple federal statute

56614 U.S. 304, 347-48 (1816) (warning that if federal courts could not supervise state court interpretations of federal law "and harmonize them into uniformity, . . the treaties ... of the United States would be different in different states, and might, perhaps, never have precisely the same construction, obligation, or efficacy, in any two states").

567 See Loewen Group, 1nc. v. United States, 42 I.L.M. 81 1, 819 I 53 (2003) (holding in a NAFTA arbitration that the United States was "responsible" for the failure of a Mississippi trial judge to conduct a fair trial for a Canadian company in accordance with the protections afforded by the NAFTA treaty); id. at 835 I 148 (holding that under international law "[a] decision of a court of a State is imputable to the State because the court is an organ of the state").

568 See Van Alstine, supra note 25, at 777 (observing that "legal and practical obstacles effectively make a formal amendment of [a multilateral] international commercial law convention impossihle").

569 See Convention on International Child Abduction, supra note 189.

570 See William Drozdiak, Germany Bows to U.S. on Custody Disputes, Wash. Post, May 30, 2000, at A1; Cindy Loose, German Promise of Visitation Applauded, WAsh. Post, May 31, 2000, at A22. 
could restore the matter to state law control. ${ }^{571}$ Moreover, the original error would not involve a breach of the treaty itself. And, unlike the reverse proposition, because the matter was not within the scope of treaty obligations in the first place, the subsequent statutory correction would not be a matter of international concern. Thus, the relative impact of error in the application of international treaties suggests that federal courts should err on the side of resolving doubtful issues through the application of a uniform rule of federal law.

\section{Treaties and Separation of Powers Concerns Regarding Federal Court Lawmaking}

. The above analysis demonstrates that the "uniquely federal interest" in defining the nation's treaty obligations militates in favor of accepting federal court authority to displace state law. Accepting this displacement assuages the paramount concern of federalism regarding federal court lawmaking. This is by no means the whole story, however. Interstitial lawmaking by federal courts in sensitive areas of international treaty law also may raise distinct separation of powers issues. Although the special constitutional role of treaties recommends a more flexible approach in this context, ${ }^{572}$ it is appropriate as a final stage in our analysis to address the concerns which animate the separation of powers doctrine with regard to the judicial application of self-executing treaties.

The most pressing of these concerns relates to institutional competence. The expansive federal power to create self-executing treaty law is of course constitutionally vested in the President and the Senate. ${ }^{573}$ These formal lawmaking bodies possess important institutional advantages over the judiciary in fact-finding and setting national policy. The President is particularly well-suited to manage sensitive issues of international diplomacy. ${ }^{574}$ The Supreme Court itself has high-

571 There would be no separation of powers concerns if Congress were to overturn an erroneous federal court decision that resolved a treaty issue as a matter of federal common law. See Whitney v. Robertson, 124 U.S. 190, 194 (1888) (stating that when an act of legislation conflicts with the self-executing provisions of a treaty, "the one last in date will control the other"); see also Breard v. Greene, 523 U.S. 371, 376 (1998) (same).

572 See Golove, supra note 10, at 1086 (arguing that "the requirements of the separation of powers may ... sometimes require a somewhat more forgiving construction when applied to treaties"); see also id. at $1287 \mathrm{n} .717$ (observing with specific regard to delegation by treaty that "given the different contexts to which treaties and laws apply, . . separation of powers principles may sometimes apply differently to treaties").

573 See supra notes $47-48$ and accompanying text.

574 See Am. Ins. Ass'n v. Garamendi, 123 S. Ct. 2374, 2386 (2003) (asserting that "the historical gloss on the 'executive Power' vested in Article II of the Constitution has recognized the President's 'vast share of responsibility for the conduct of our foreign relations'" (quoting Youngstown Sheet \& Tube Co. v. Sawyer, 343 U.S. 579, 610-11 (1952) (Frankfurter, J., concurring))); Sale v. Haitian Ctrs. Council, Inc., 509 U.S. 155, 188 (1993) (observing that the President has "unique responsibility" regarding "foreign and military 
lighted these institutional advantages over federal courts regarding foreign affairs matters. ${ }^{575}$

Nonetheless, the application of self-executing treaties, like other forms of federal law, falls within the formal province of the federal judiciary. ${ }^{576}$ Moreover, foreign affairs implications can differ substantially from treaty to treaty. Some treaties may directly regulate the rights and obligations of the United States in its international conduct as a sovereign entity or otherwise touch on delicate subjects of international diplomacy. The Geneva Convention Relative to the Treatment of Prisoners of War might provide a good example here. ${ }^{577}$ For treaties of this nature, judicial application may have a substantial impact on the nation's foreign affairs and the executive branch's international conduct under the treaty. ${ }^{578}$

But not all treaties implicate such issues to the same extent. As the Supreme Court insightfully recognized in Banco Nacional de Cuba v. Sabbatino, ${ }^{579}$ such differences play an important role in assessing the propriety of judicial action: "It is also evident that some aspects of international law touch much more sharply on national nerves than do others; the less important the implications of an issue are for our

affairs"); First Nat'l City Bank v. Banco Nacional de Cuba, 406 U.S. 759, 767 (1972) (plurality opinion) (stating that the President has "the lead role . . . in foreign policy"); $c f$. Mistretta v. United States, 488 U.S. 361, 383 (1989) (noting with regard to delegation that "we have expressed our vigilance against [the] danger[ ] . . . that the Judicial Branch neither be assigned nor allowed 'tasks that are more properly accomplished by [other] branches'" (third alteration in original) (quoting Morrison v. Olson, 487 U.S., 654, 680-81 (1988))).

575 See, e.g., Benz v. Compania Naviera Hidalgo, S.A., 353 U.S. 138, 147 (1957) (stating that for the Court to "run interference in . . . a delicate field of international relations there must be present the affirmative intention of the Congress clearly expressed. It alone has the facilities necessary to make fairly such an important policy decision where the possibilities of international discord are so evident and retaliative action so certain"); Chi. \& S. Air Lines, Inc. v Waterman S.S. Corp., 333 U.S. 103, 111 (1948) (affirming that delicate issues of foreign policy are matters "for which the Judiciary has neither aptitude, facilities nor responsibility and which [have] long been held to belong in the domain of political power not subject to judicial intrusion or inquiry").

576 See supra notes 325-28 and accompanying text (examining this point in detail).

577 See Convention Relative to the Treatment of Prisoners of War, Aug. 12, 1949, 6 U.S.T. 3316, 75 U.N.T.S. 135. Some courts have held that this treaty is self-executing. See United States v. Lindh, 212 F. Supp. 2d 541, 553-54 (E.D. Va. 2002) (holding that certain provisions of the convention are self-executing and thus "are a part of American law . . binding in federal courts under the Supremacy Clause" and noting that this point "[was] essentially conceded by the [U.S.] government"); United States v. Noriega, 808 F. Supp. 791,799 (S.D. Fla. 1992) (" $[\mathrm{I}] \mathrm{t}$ is inconsistent with both the language and spirit of the [convention] and with our professed support of its purpose to find that the rights established therein cannot be enforced by the individual POW in a court of law.").

578 See Van Alstine, supra note 19, at 1298-1302 (arguing that federal courts should accord only "calibrated deference" to executive branch interpretations of treaties, but that this deference should be greatest for diplomatic, national defense, and related treaties, where the foreign affairs implications and executive branch expertise are highest).

579376 U.S. 398 (1964). 
foreign relations, the weaker the justification for exclusivity in the political branches." 580

This suggests an interpretive spectrum for the discretionary powers of federal courts. As tbe substantive subject of a treaty moves closer to regulating the international conduct of the United States as a sovereign entity, separation of powers concerns may counsel increased caution by federal courts. This does not mean, of course, that courts may not accept an express (or even implied) delegation in such circumstances. Nor does the mere existence of potential foreign affairs implications transform all related issues into political questions beyond the competence of the courts. ${ }^{581}$ But the fact that a treaty creates obligations for the executive branch in its international conduct on behalf of the United States provides an important interpretive context. For such treaties, it is appropriate for federal courts to be circumspect in accepting that the President and Senate implicitly delegated the authority to affect those obligations, in the absence of specific guidance from the treaty itself. ${ }^{582}$

Even here, however, the existence of heightened separation of powers concerns does not mean that federal courts sbould defer to state law by default. If an unresolved issue is within the scope of a treaty, it remains a matter of supreme federal law. In such a case, federal courts have the constitutional obligation to ensure that state law does not apply in an area subsumed within federal law by the treaty. This obligation may also demand that federal courts supply their own, uniform federal law solution for the unresolved issue, even

$580 \quad I d$. at 428.

581 See, e.g., Baker v. Carr, 369 U.S. 186, 211 (1962) (observing that "it is error to suppose that every case or controversy which touches foreign relations lies beyond judicial cognizance"); Planned Parenthood Fed'n of Am., Inc. v. Agency for Int'l Dev., 838 F.2d 649, 655 (2d Cir. 1988) (stating, with regard to a First Amendment challenge to international family planning grants, that " $[t]$ he fact that this case involves foreign affairs, an area constitutionally committed to the executive and legislative branches, does not end the court's inquiry as to whether the action presents a political question"); Hopson v. Kreps, 622 F.2d 1375, 1377, 1380-82 (9th Cir. 1980) (rejecting an executive branch argument that "interpretation of the [1946 International Whaling] Convention "[was so] intertwined with foreign policy considerations that [a] court has no jurisdiction to consider the validity of the [relevant Commerce Department] regulations" (quoting Hopson v. Kreps, $462 \mathrm{~F}$. Supp. 1374, 1378 (D. Alaska 1979) (third alteration in original))).

582 The Supreme Court's opinion in United States $v$. Alvarez-Machain, 504 U.S. 655 (1992), provides a possible illustration of this approach. There, the Court refused to recognize an implied rule in an extradition treaty that would have prohibited forced abductions by executive branch officials. See id. at 667-69. Admittedly, the Court did not analyze the issue as one of implied interstitial lawmaking powers, and there is much else to criticize in the opinion. See Bederman, supra note 25, at 1013-14 (criticizing the opinion as contrary to accepted principles of treaty interpretation). The Supreme Court's analysis is nonetheless consistent with the idea that federal courts should exercise greater caution before concluding that a treaty authorizes the creation of implied limitations on the rights of the United States in its international conduct as a sovereign entity. 
where separation of powers concerns are substantial. The point here, however, is that in making such determinations federal courts should show the greatest care to avoid encroaching on the legitimate interests of the executive branch or otherwise extending the treaty beyond its intended scope.

At the other end of the interpretive spectrum, however, are private law treaties that define no continuing formal obligations for the executive branch. A variety of self-executing (often multilateral) treaties regulate only the relations between private parties. ${ }^{583}$ Recall the prominent example of the UN Sales Convention, which solely defines rights and obligations as between private parties involved in defined international commercial law transactions. ${ }^{584}$ With such treaties, the separation of powers concerns are the least salient, for interstitial lawmaking by federal courts in the definition of private rights and obligations in such a context does not interfere with the international conduct of the executive branch.

Correspondingly, when unresolved issues arise within the scope of these private law treaties, ${ }^{585}$ the premise of a federal law solution, supplied as necessary by federal courts, should be strongest. Moreover, even without an express uniformity directive, ${ }^{586}$ a presumption of implied developmental authority should also arise, as with domestic law statutes, ${ }^{587}$ when treaty-lawmakers adopt broad, open-textured provisions. A similar conclusion may emerge from the unambiguous purpose of a treaty. 588

583 See, e.g., supra notes 173-79 and accompanying text (citing international commercial law conventions); supra notes $187-88$ and accompanying text (citing civil procedure conventions).

584 See supra notes 173-74, 406-12 and accompanying text (analyzing this self-executing commercial law treaty).

$585 C f$. Van Alstine, supra note 25, at 705-06 (referring to these treaties as "legislative treaties"). As emphasized in the text above, Article I legislation and self-executing treaties are of course distinct forms of federal law that arise from distinct sources of authority. See supra notes 334-50 and accompanying text. The point of tbe label "legislative treaties" is that self-executing treaties which solely regulate private rights and obligations arise in a different interpretive context and require different interpretive principles as compared with those treaties that regulate the sovereign powers of the United States. See Van Alstine, supra note 19, at 1278-80 (explaining this important difference between the substantive subjects of treaties).

586 See supra notes 528-29 and accompanying text.

587 See supra notes 243-52 and accompanying text (describing this presumption in the statutory context); see also, e.g., Touby v. United States, 500 U.S. 160, 165 (1991) ("Congress does not violate the Constitution merely because it legislates in broad terms, leaving a certain degree of discretion to . . judicial actors."); Northwest Airlines, Inc. v. Transp. Workers Union, 451 U.S. 77, 95 (1981) ("Broadly worded . . statutory provisions necessarily have been given concrete meaning and application by a process of case-by-case judicial decision in the common-law tradition.").

588 See Japan Line, Ltd. v. County of Los Angeles, 441 U.S. 434, 453 (1979) (holding that, although it contained no express uniformity directive, the Customs Convention on Containers reflected "a national policy to remove impediments to the use of containers" in 
Nonetheless, it is important to note for all of these cases that the exercise of discretion by federal courts is of an interstitial nature only. Faithful to the separation of powers doctrine, federal courts must in all cases look first to the text, purpose, and drafting history of a treaty even in the exercise of their implied gap-filling authority. Only when these more direct sources of guidance fail will federal courts have the responsibility to serve the needs of national uniformity by crafting a uniform rule of federal law.

General interests of uniformity, of course, will not be sufficient for issues beyond the scope of a particular treaty. Rather, a necessary prerequisite is that - as fortified by the federal law premise discussed above $^{589}$ - the unresolved issue must reflect an unintended gap (a gap praeter legem) in a treaty. ${ }^{590}$ This rule in essence comprised the Supreme Court's factual conclusion in Zicherman v. Korean Airlines Co. ${ }^{591}$ At issue there was a specific regulatory gap in the Warsaw Convention governing international air transportation. ${ }^{592}$ The Court held that although in general the treaty pursued international uniformity, the specific issue in dispute was "not an area in which the imposition of uniformity was found feasible." 593 It thus concluded that the Convention did not "empower [the Court] to develop some common-law rule . . . that will supersede the normal federal disposition." 594

On the narrow issue in dispute, Zicherman's factual conclusion may be correct. The problem, however, is that the Court failed to engage in any rigorous analysis of the possibility of an implied authorization of interstitial lawmaking powers by the federal courts. ${ }^{595}$ Moreover, the decision's broad rhetoric has led lower federal courts to expand the conclusion from one narrow issue to a generalized notion that the Warsaw Convention never allows gap-filling to advance the interests of national uniformity. ${ }^{596}$

international commerce and thus it displaced state law taxation rules that "frustrate[d] attainment of federal uniformity"). But see Itel Containers lnt'l Corp. v. Huddleston, 507 U.S. 60, 70 (1993) (observing that the Japan Line Court "did not hold that the Customs Convention [on Containers] and the federal regulatory scheme for cargo containers expressed a national policy to exempt containers from all domestic taxation").

589 See discussion supra Part IV.B.1.

$590 \quad$ See discussion supra Part IV.B.2.b.

591516 U.S. 217 (1996).

592 See id. at 221 .

593 Id. at 230.

594 Id. at 229.

595 Interestingly, the court ultimately finessed the issue of national uniformity by resorting to a separate federal statute to fill the gap in the treaty. See id. at 230-31.

596 See Ins. Co. of N. Am. v. Fed. Express Corp., 189 F.3d 914, 920-21 (9th Cir. 1999) (citing Zicherman and holding that the court must "refrain from fashioning a federal common law meaning to the term wilful misconduct" under the Warsaw Convention); Pescatore v. Pan Am. World Airways, Inc., 97 F.3d 1, 9 (2d Cir. 1996) (holding generally that the Warsaw Convention does not authorize federal common law and thus refusing to fill a separate gap in the Convention). 
A final note is appropriate here with regard to separation of powers and executive branch expertise. Because of the President's special responsibilities in foreign affairs, federal courts may properly accord some respect to the views of the executive branch on issues of treaty interpretation. ${ }^{597}$ Not all treaties affect foreign affairs equally, however. ${ }^{598}$ Nor is there any compelling reason to assume overriding executive branch expertise, as compared with standard means of judicial interpretation, across the full range of substantive treaty law. Specialized commercial law treaties again provide a good example.599 In short, as the foreign affairs and diplomacy implications of a treatyand thus the assumptions about executive expertise-diminish, so too will the separation of powers concerns about judicial intrusion into fields of exclusive executive branch competence.

\section{CONCLUSION}

For the foreseeable future, most of the difficult work of legal regulation will remain the province of traditional domestic legislation. Just as the rise of shared national economic and social concerns spurred federal statutory solutions in the last century, however, so too has global interaction in recent decades increasingly compelled regulation through comprehensive international treaties.

The analysis here demonstrates that many of the traditional assumptions about the relationship of federal law with state law fit poorly, and upon careful reflection, most likely not at all in the treaty context. Founded on a premise of competing lawmaking powers, the presumption against preemption of state law by Article I legislation, for instance, makes little sense for exercises of the exclusive federal authority over international treatymaking. Likewise, the special constitutional character of self-executing treaties fundamentally changes the calculus for understanding the role of federal courts in applying this form of federal law.

597 In recent years, the Supreme Court has described this proposition in quite measured terms. See El Al Isr. Airlines, Ltd. v. Tsui Yuan Tseng, 525 U.S. 155, 168 (1999) (observing that federal courts "ordinarily" should give "[r] espect" to the "reasonable views of the [e]xecutive [b] ranch concerning the meaning" of a treaty); see also Itel Containers Int'l Corp. v. Huddleston, 507 U.S. 60, 85 (1993) (Blackmun, J., dissenting) (stating that executive branch opinions about the displacement of state law and the compliance of a treaty with other constitutional prohibitions, "consistent with the separation of powers, may not be given any weight beyond its power to persuade").

598 See supra notes 577-83 and accompanying text.

599 See Van Alstine, supra note 19, at 1301-02 (observing, with regard to arguments about executive branch expertise, that specialized commercial law treaties in fields such as "the international sale of goods, receivables financing, and security interests in moveable equipment" are drafted by "[e]xperts in the respective fields ... under the auspices of permanent international institutions, some of which are nongovernmental"). 
The equal constitutional status of treaties and statutes means at a minimum that an express delegation of circumscribed lawmaking powers through a treaty does not violate the limitations on federal judicial lawmaking. To be sure, foreign affairs implications do not alone transform all issues of treaty law into proper subjects for federal court lawmaking. But a recognition of the status of treaties as formal expressions of national foreign affairs policy, coupled with the vital need for uniformity in the sovereign obligations of the United States, mandates a more accommodating approach to implied interstitial federal court lawmaking within the scope of self-executing treaties. 